Nevada

Environmental

Restoration

Project

Corrective Action Decision

Document/Corrective Action Plan

for Corrective Action Unit 98:

Frenchman Flat

Nevada National Security Site,

Nevada

Controlled Copy No.:

Revision No.: 1

July 2011

Approved for public release; further dissemination unlimited.

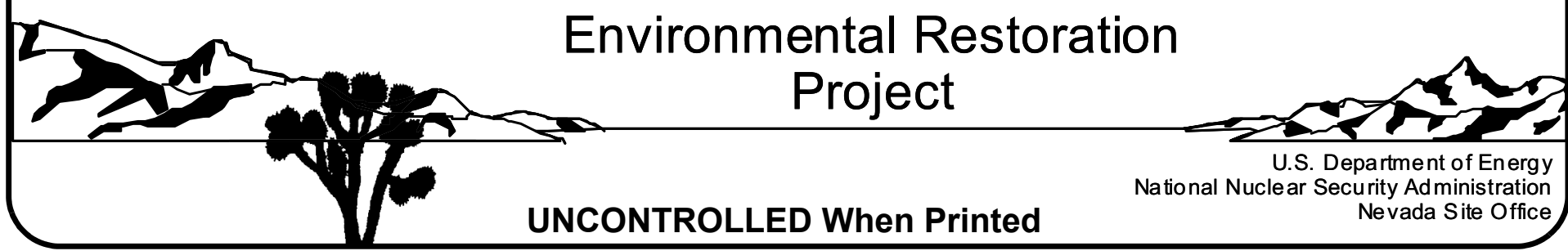


Available for sale to the public from:

U.S. Department of Commerce

National Technical Information Service

5301 Shawnee Road

Alexandria, VA 22312

Telephone: 800.553 .6847

Fax: 703.605.6900

E-mail: orders@ntis.gov

Online Ordering: http://www.ntis.gov/help/ordermethods.aspx

Available electronically at http://www.osti.gov/bridge

Available for a processing fee to U.S. Department of Energy and its contractors, in paper, from:

U.S. Department of Energy

Office of Scientific and Technical Information

P.O. Box 62

Oak Ridge, TN 37831-0062

Phone: 865.576 .8401

Fax: 865.576.5728

Email: reports@adonis.osti.gov

Reference herein to any specific commercial product, process, or service by trade name, trademark, manufacturer, or otherwise, does not necessarily constitute or imply its endorsement, recommendation, or favoring by the United States Government or any agency thereof or its contractors or subcontractors. 


\title{
CORRECTIVE ACTION DECISION DOCUMENT/CORRECTIVE ACTION PLAN FOR CORRECTIVE ACTION UNIT 98: FRENCHMAN FLAT NEVADA NATIONAL SECURITY SITE, NEVADA
}

\author{
U.S. Department of Energy \\ National Nuclear Security Administration \\ Nevada Site Office \\ Las Vegas, Nevada
}

Controlled Copy No.:

Revision No.: 1

July 2011

Approved for public release; further dissemination unlimited.

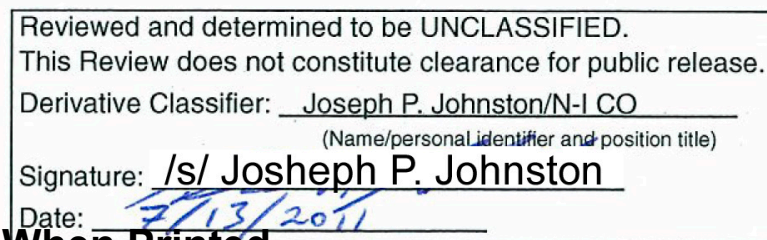




\section{CORRECTIVE ACTION DECISION \\ DOCUMENT/CORRECTIVE ACTION PLAN \\ FOR CORRECTIVE ACTION UNIT 98: FRENCHMAN FLAT \\ NEVADA NATIONAL SECURITY SITE, NEVADA}

Approved by: /s/ Wilhelm R. Wilborn

Bill Wilborn

Federal Sub-Project Director

Underground Test Area Sub-Project

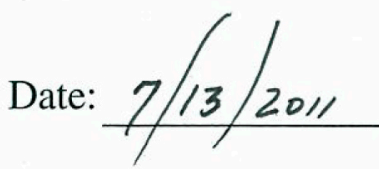

Date: $7 / 13 / 2011$

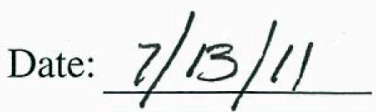

Robert F. Boehlecke

Federal Project Director

Environmental Restoration Project 


\section{Table of Contents}

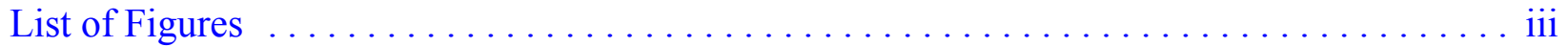

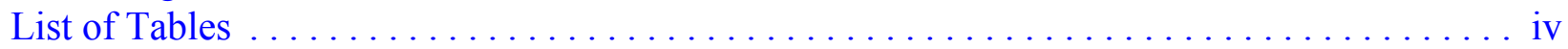

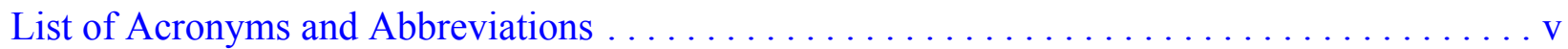

List of Symbols for Elements and Compounds $\ldots \ldots \ldots \ldots \ldots \ldots \ldots \ldots \ldots$ viii

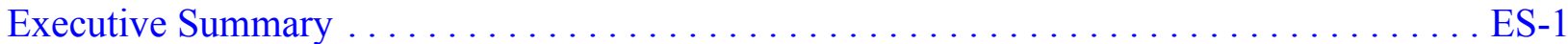

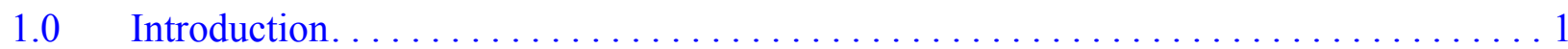

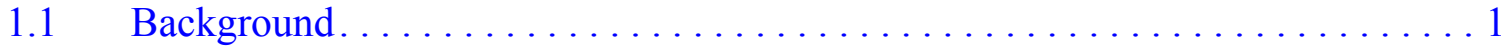

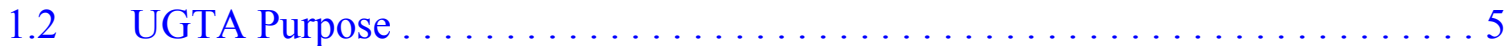

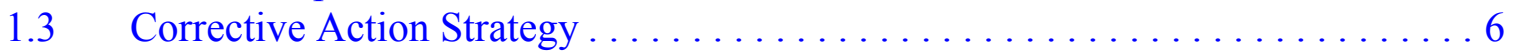

$2.0 \quad$ Corrective Action Investigation Summary $\ldots \ldots \ldots \ldots \ldots \ldots \ldots \ldots \ldots \ldots \ldots \ldots \ldots \ldots \ldots$

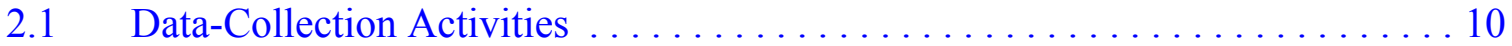

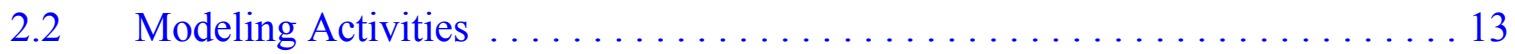

2.2.1 Hydrostratigraphic Framework Models . . . . . . . . . . . . . 16

2.2.2 Groundwater Flow Models....................... 17

2.2.3 Contaminant Transport Models . . . . . . . . . . . . . . . . 19

2.3 Contaminant Boundaries. . . . . . . . . . . . . . . . . . . . . . . . . . . 21

$2.4 \quad$ Phase II Peer Review . . . . . . . . . . . . . . . . . . . . . . . . . . . . 27

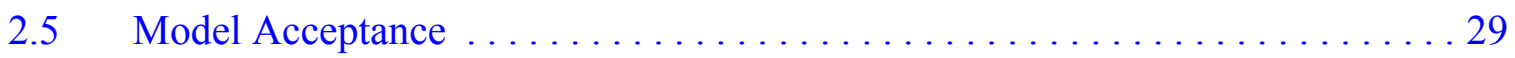

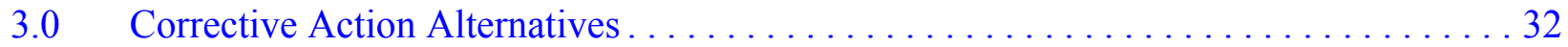

$3.1 \quad$ Corrective Action Objective .......................... 32

3.2 Recommended Corrective Action Alternative $\ldots \ldots \ldots \ldots \ldots \ldots \ldots \ldots . \ldots \ldots 2$

4.0 Implementation of the Corrective Action Plan ...................... 37

$4.1 \quad$ Use Restriction Boundaries . . . . . . . . . . . . . . . . . . . . . . . . . . 37

4.2 CAU Regulatory Boundary Objectives $\ldots \ldots \ldots \ldots \ldots \ldots \ldots \ldots \ldots \ldots$

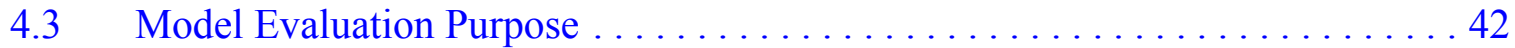

$4.4 \quad$ Model Evaluation Approach............................. 42

4.4.1 Model Evaluation Process . . . . . . . . . . . . . . . . 44

$4.5 \quad$ Data-Collection Activities . . . . . . . . . . . . . . . . . . . . . 48

4.5.1 Ground Magnetic Surveys ..................... 48

4.5.2 Model Evaluation Wells near PIN STRIPE and MILK SHAKE. . . . . 50

4.5.3 Water-Level Measurement Program .................. 55

$4.6 \quad$ Waste Management. ................................. 56

$4.7 \quad$ Reporting Requirements .............................. 57

$5.0 \quad$ References.......................................... 59 


\section{Table of Contents (Continued)}

Appendix A - NNSA/NSO Letter Requesting Acceptance of the Frenchman Flat Flow and Transport Model, and Documenting Responses to Phase II Peer Review

Appendix B - NDEP Letter Accepting the Frenchman Flat Flow and Transport Model Appendix C - Nevada Division of Environmental Protection Comments 


\section{List of Figures}

Number

Title

Page

1-1 Location of the Frenchman Flat Corrective Action Unit. . . . . . . . . . . . 2

1-2 Location of Underground Nuclear Tests and Wells in Frenchman Flat . . . . . . 4

1-3 UGTA Strategy Flowchart $\ldots \ldots \ldots \ldots \ldots \ldots \ldots \ldots \ldots \ldots \ldots \ldots$

2-1 Components of the Flow and Contaminant Transport Model . . . . . . . . . 15

2-2 Frenchman Flat Contaminant Boundaries................. 23

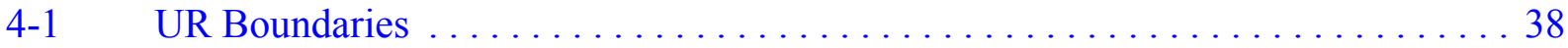

4-2 Rock Valley Fault System in the Vicinity of Frenchman Flat . . . . . . . . . 40

4-3 Rock Valley Fault System. . . . . . . . . . . . . . . . . 43

4-4 Process Flow Diagram for CADD/CAP Model Evaluation Process . . . . . . . . . 45

4-5 Recommended Locations for the Frenchman Flat

Model Evaluation Wells . . . . . . . . . . . . . . . . . . . . . 52

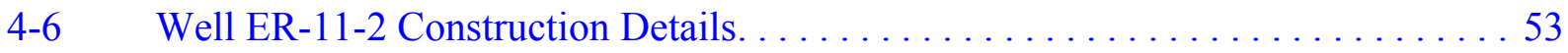

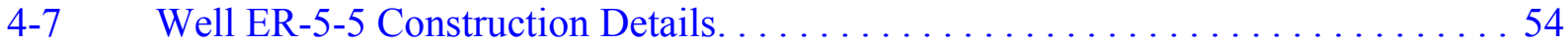




\section{List of Tables}

Number

Title

Page

1-1 Corrective Action Sites in the Frenchman Flat Corrective Action Unit. . . . . . . . 3

2-1 Data-Collection Activities Performed during the Phase II CAI . . . . . . . . . 11

2-2 Radionuclide Regulatory Groups $\ldots \ldots \ldots \ldots \ldots \ldots \ldots \ldots \ldots \ldots \ldots \ldots \ldots \ldots \ldots \ldots$

2-3 Maximum Saturated Zone Dimensions of Contaminant Boundary for Each Source . . . . . . . . . . . . . . . . . . . . 24

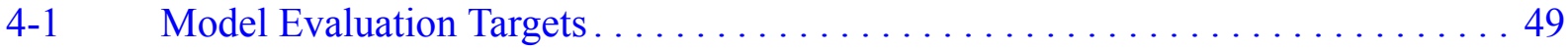

4-2 Model Evaluation Target and Potential Data-Collection Activities . . . . . . . . . 51 


\section{List of Acronyms and Abbreviations}

3-D

AA

ALARA

amsl

BLFA

BLM

$\mathrm{BN}$

CADD

CAI

CAIP

CAP

CAS

CAU

$\mathrm{COC}$

CPBA

CR

CS

DETA

DISP

DoD

DOE

$\mathrm{DOE} / \mathrm{NV}$

DRIA

DVRFS

EPA

FEHM

FFACO
Three-dimensional

Alluvial aquifer

As low as reasonably achievable

Above mean sea level

Basalt lava-flow aquifer

Bureau of Land Management

Bechtel Nevada

Corrective action decision document

Corrective action investigation

Corrective action investigation plan

Corrective action plan

Corrective action site

Corrective action unit

Contaminant of concern

CP thrust fault

Closure report

Carbon steel

Detachment fault

Displacement fault (aquifer juxtaposition)

U.S. Department of Defense

U.S. Department of Energy

U.S. Department of Energy, Nevada Operations Office

Desert Research Institute recharge with alluvial mask

Death Valley Regional Ground-Water Flow System

U.S. Environmental Protection Agency

Finite element heat-mass

Federal Facility Agreement and Consent Order 


\section{List of Acronyms and Abbreviations (Continued)}

FIMS

FMP

HFM

HST

HSU

id

IDW

in.

IT

$\mathrm{K}_{\mathrm{d}}$

$\mathrm{km}$

$\mathrm{km}^{2}$

$\mathrm{kt}$

LANL

LCA

LLNL

LTCU

LVTA

$\mathrm{m}$

MME

MWAT

NAD

NDEP

NHA

NNES

NNSA/NSO

NNSS
Facility Information Management System

Field Management Plan

Hydrostratigraphic framework model

Hydrologic source term

Hydrostratigraphic unit

Inner diameter

Investigation-derived waste

Inch

IT Corporation

Distribution coefficient

Kilometer

Square kilometer

Kiloton

Los Alamos National Laboratory

Lower carbonate aquifer

Lawrence Livermore National Laboratory

Lower tuff confining unit

Lower vitric-tuff aquifer

Meter

Modified Maxey-Eakin recharge distribution

Multiple-well aquifer test

North American Datum

Nevada Division of Environmental Protection

Northern Hydrologic Alternative

Navarro Nevada Environmental Services, LLC

U.S. Department of Energy, National Nuclear Security Administration Nevada Site Office

Nevada National Security Site 


\section{List of Acronyms and Abbreviations (Continued)}

\begin{tabular}{|c|c|}
\hline NTS & Nevada Test Site \\
\hline NTTR & Nevada Test and Training Range \\
\hline OAA & Older alluvial aquifer \\
\hline od & Outer diameter \\
\hline OSHA & Occupational Safety and Health Administration \\
\hline PEST & Parameter estimation software \\
\hline QAPP & Quality Assurance Project Plan \\
\hline RCRA & Resource Conservation and Recovery Act \\
\hline REOP & Real Estate/Operations Permit \\
\hline RNM & Radionuclide migration \\
\hline RWMC & Radioactive waste management complex \\
\hline SDWA & Safe Drinking Water Act \\
\hline SNJV & Stoller-Navarro Joint Venture \\
\hline $\mathrm{SS}$ & Stainless steel \\
\hline TBD & To be determined \\
\hline TM-LVTA & Timber Mountain lower vitric-tuff aquifer \\
\hline TM-WTA & Timber Mountain welded-tuff aquifer \\
\hline TSA & Topopah Spring aquifer \\
\hline UGTA & Underground Test Area \\
\hline UR & Use restriction \\
\hline USAF & U.S. Air Force \\
\hline USGSD & U.S. Geological Survey recharge with redistribution \\
\hline UTM & Universal Transverse Mercator \\
\hline VOIA & Value of information analysis \\
\hline WMP & Waste Management Plan \\
\hline WTA & Welded-tuff aquifer \\
\hline WW & Water Well \\
\hline
\end{tabular}




\section{List of Symbols for Elements and Compounds}

\begin{tabular}{|c|c|}
\hline $\mathrm{Al}$ & Aluminum \\
\hline Am & Americium \\
\hline Ar & Argon \\
\hline $\mathrm{C}$ & Carbon \\
\hline $\mathrm{Ca}$ & Calcium \\
\hline $\mathrm{Cd}$ & Cadmium \\
\hline $\mathrm{Cl}$ & Chlorine \\
\hline $\mathrm{Cm}$ & Curium \\
\hline Cs & Cesium \\
\hline $\mathrm{Eu}$ & Europium \\
\hline${ }^{3} \mathrm{H}$ & Tritium \\
\hline Ho & Holmium \\
\hline I & Iodine \\
\hline K & Potassium \\
\hline $\mathrm{Kr}$ & Krypton \\
\hline $\mathrm{Nb}$ & Niobium \\
\hline $\mathrm{Ni}$ & Nickel \\
\hline $\mathrm{Np}$ & Neptunium \\
\hline $\mathrm{Pd}$ & Palladium \\
\hline $\mathrm{Pu}$ & Plutonium \\
\hline $\mathrm{Sm}$ & Samarium \\
\hline $\mathrm{Sn}$ & Tin \\
\hline $\mathrm{Sr}$ & Strontium \\
\hline $\mathrm{Tc}$ & Technetium \\
\hline $\mathrm{Th}$ & Thorium \\
\hline $\mathrm{U}$ & Uranium \\
\hline $\mathrm{Zr}$ & Zirconium \\
\hline
\end{tabular}




\section{Executive Summary}

This Corrective Action Decision Document (CADD)/Corrective Action Plan (CAP) has been prepared for Corrective Action Unit (CAU) 98, Frenchman Flat, Nevada National Security Site (NNSS), Nevada. This work was performed as part of the U.S. Department of Energy, National Nuclear Security Administration Nevada Site Office (NNSA/NSO) Underground Test Area (UGTA) Sub-Project in accordance with the Federal Facility Agreement and Consent Order (FFACO).

This CADD/CAP is a part of the corrective action process described in the FFACO. It follows the Corrective Action Investigation (CAI) stage, which results in development of a set of contaminant boundary forecasts produced from groundwater flow and contaminant transport modeling of the Frenchman Flat CAU. The Frenchman Flat CAU is located in the southeastern portion of the NNSS and comprises 10 underground nuclear tests. The tests were conducted between 1965 and 1971 and resulted in the release of radionuclides in the subsurface in the vicinity of the test cavities.

Two important aspects of the corrective action process are presented within this CADD/CAP. The CADD portion describes the results of the Frenchman Flat CAU data-collection and modeling activities completed during the CAI stage. The corrective action objectives and the actions recommended to meet the objectives are also described. The CAP portion describes the corrective action implementation plan. The CAP begins with the presentation of CAU regulatory boundary objectives and initial use restriction boundaries that are identified and negotiated by NNSA/NSO and the Nevada Division of Environmental Protection (NDEP). The CAP also presents the model evaluation process designed to build confidence that the flow and contaminant transport modeling results can be used for the regulatory decisions required for CAU closure.

The UGTA strategy assumes that active remediation is not feasible with current technology. As a result, the corrective action is based on a combination of characterization and modeling studies, monitoring, and institutional controls. The strategy is implemented through a four-stage approach that comprises the following: (1) Corrective Action Investigation Plan (CAIP), (2) CAI, (3) CADD/CAP, and (4) Closure Report (CR) stages.

The first two stages of the strategy have been completed for the Frenchman Flat CAU. A value of information analysis and a CAIP were developed during the CAIP stage. During the CAI stage, a CAIP addendum was developed, and the activities proposed in the CAIP and addendum were 
completed. These activities included hydrogeologic investigation of the underground testing areas, aquifer testing, isotopic and geochemistry-based investigations, and integrated geophysical investigations. After these investigations, a groundwater flow and contaminant transport model was developed to forecast contaminant boundaries that enclose areas potentially exceeding the Safe Drinking Water Act radiological standards at any time within 1,000 years. An external peer review of the groundwater flow and contaminant transport model was completed, and the model was accepted by NDEP to allow advancement to the CADD/CAP stage.

The CADD/CAP stage focuses on model evaluation to ensure that existing models provide adequate guidance for the regulatory decisions regarding monitoring and institutional controls. Data-collection activities are identified and implemented to address key uncertainties in the flow and contaminant transport models. During the CR stage, final use restriction boundaries and CAU regulatory boundaries are negotiated and established; a long-term closure monitoring program is developed and implemented; and the approaches and policies for institutional controls are initiated.

The model evaluation process described in this plan consists of an iterative series of five steps designed to build confidence in the site conceptual model and model forecasts. These steps are designed to identify data-collection activities (Step 1), document the data-collection activities in the CADD/CAP (Step 2), and perform the activities (Step 3). The new data are then assessed; the model is refined, if necessary; the modeling results are evaluated; and a model evaluation report is prepared (Step 4). The assessments are made by the modeling team and presented to the pre-emptive review committee. The decision is made by the modeling team with the assistance of the pre-emptive review committee and concurrence of NNSA/NSO to continue data and model assessment/refinement, recommend additional data collection, or recommend advancing to the CR stage. A recommendation to advance to the CR stage is based on whether the model is considered to be sufficiently reliable for designing a monitoring system and developing effective institutional controls. The decision to advance to the CR stage or to return to step 1 of the process is then made by NDEP (Step 5).

The data-collection and evaluation activities identified for the first iteration of the model evaluation process for the Frenchman Flat CAU include drilling and testing two model-evaluation wells; performing ground magnetic surveys; developing and implementing a water-level measurement program in Frenchman Flat; evaluating the geologic and hydrologic data; and refining the groundwater flow and transport model, if necessary. 


\subsection{Introduction}

This Corrective Action Decision Document (CADD)/Corrective Action Plan (CAP) has been prepared for Corrective Action Unit (CAU) 98, Frenchman Flat, Nevada National Security Site (NNSS), Nevada. Two important aspects of the corrective action process for the Frenchman Flat CAU are presented. The CADD portion describes the results of data-collection and modeling activities completed for the Frenchman Flat CAU, and also describes the corrective action objectives and the corrective actions recommended to meet the objectives. The CAP portion describes the implementation plan for the corrective action. The CAP begins with a description of the CAU regulatory boundary objectives and initial use restriction (UR) boundaries negotiated by the U.S. Department of Energy (DOE), National Nuclear Security Administration Nevada Site Office (NNSA/NSO) and the Nevada Division of Environmental Protection (NDEP). A model evaluation

process to assess the reliability of model results through data collection and model refinement is then described. The goal of this process is to build confidence that the flow and contaminant transport modeling results can be used for the regulatory decisions required for CAU closure. The corrective actions recommended in this document are in accordance with the Federal Facility Agreement and Consent Order (FFACO) (1996, as amended) that was agreed to by the State of Nevada; DOE, Environmental Management; U.S. Department of Defense (DoD); and DOE, Legacy Management.

\subsection{Background}

Frenchman Flat is one of five CAUs on the NNSS (formerly the Nevada Test Site [NTS]) assigned to the NNSA/NSO Underground Test Area (UGTA) Sub-Project. The NNSS is approximately 65 miles northwest of Las Vegas, Nevada. Frenchman Flat, located in the southeastern portion of the NNSS (Figure 1-1), was used for underground nuclear testing from 1965 to 1971 (Table 1-1). Seven tests were detonated in the northern part of the CAU (informally called the Northern Testing Area), and three were detonated in the central part (informally called the Central Testing Area) (DOE/NV, 1999) (Figure 1-2). All 10 tests were detonated in the alluvium except for PIN STRIPE, which was detonated within vitric tuff. All 10 tests were conducted above but near the water table, except for CAMBRIC. All 10 tests have yields less than 20 kilotons (kt) (Table 1-1). The announced yield at CAMBRIC is $0.75 \mathrm{kt}$, and the announced yield at DERRINGER is $7.8 \mathrm{kt}$. The remaining eight test yields are specified as less than $20 \mathrm{kt}$ (DOE/NV, 2000b). 


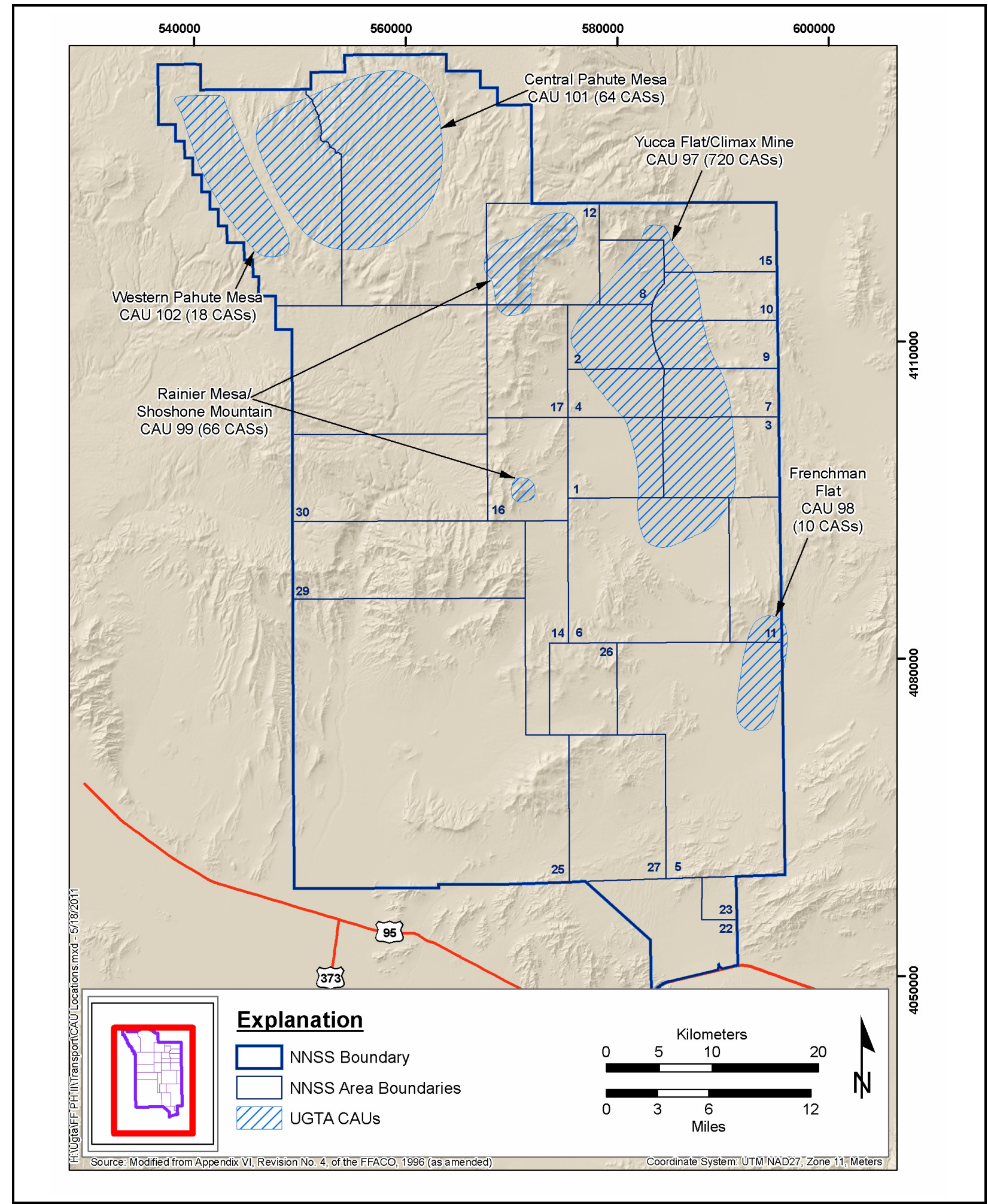

Figure 1-1

Location of the Frenchman Flat Corrective Action Unit 
Table 1-1

Corrective Action Sites in the Frenchman Flat Corrective Action Unit

\begin{tabular}{|c|c|c|c|c|c|c|c|c|c|}
\hline Test Name & $\begin{array}{c}\text { CAS } \\
\text { Number }\end{array}$ & $\begin{array}{c}\text { Hole } \\
\text { Name }^{a}\end{array}$ & Test Date $^{a}$ & $\begin{array}{l}\text { UTM Zone 11, } \\
\text { NAD } 27 \\
(\mathrm{~m})\end{array}$ & $\begin{array}{c}\text { Yield } \\
\text { Range }^{a} \\
\text { (kt) }\end{array}$ & $\begin{array}{l}\text { Surface } \\
\text { Elevation } \\
\text { (m amsl) }\end{array}$ & $\begin{array}{l}\text { Hole } \\
\text { Depth } \\
\text { (m) }\end{array}$ & $\begin{array}{c}\text { Working } \\
\text { Point Depth } \\
\text { (m) }\end{array}$ & $\begin{array}{c}\text { Working } \\
\text { Point } \\
\text { HSU }\end{array}$ \\
\hline \multicolumn{10}{|c|}{ Central Testing Area } \\
\hline CAMBRIC & $05-57-003$ & U5e & 05/14/1965 & $\begin{array}{c}\text { E 592142.7 } \\
\text { N 4075575.4 }\end{array}$ & 0.75 & 956.2 & 304.8 & 295 & AA \\
\hline DILUTED WATERS & $05-57-002$ & U5b & 06/16/1965 & $\begin{array}{c}\text { E 593110.1 } \\
\text { N } 4074994.0\end{array}$ & $<20$ & 943.4 & 205.7 & 193 & AA \\
\hline WISHBONE & $05-57-001$ & U5a & 02/18/1965 & $\begin{array}{c}\text { E } 593719.6 \\
\text { N } 4074996.1 \\
\end{array}$ & $<20$ & 940.6 & 191.4 & 175 & AA \\
\hline \multicolumn{10}{|c|}{ Northern Testing Area } \\
\hline DERRINGER & $05-57-004$ & U5i & 09/12/1966 & $\begin{array}{c}\text { E 593518.3 } \\
\text { N 4081415.4 }\end{array}$ & 7.8 & $1,034.8$ & 249.9 & 255 & OAA \\
\hline DIAGONAL LINE & $11-57-005$ & U11g & $11 / 24 / 1971$ & $\begin{array}{c}\text { E 594939.1 } \\
\text { N } 4081801.6\end{array}$ & $<20$ & $1,037.8$ & 277.4 & 264 & OAA \\
\hline DIANA MOON & $11-57-003$ & U11e & 08/27/1968 & $\begin{array}{c}\text { E 595265.3 } \\
\text { N 4081581.8 }\end{array}$ & $<20$ & $1,031.8$ & 254.5 & 242 & OAA \\
\hline MILK SHAKE & $05-57-005$ & U5k & 03/25/1968 & $\begin{array}{c}\text { E 595267.2 } \\
\text { N 4080972.3 }\end{array}$ & $<20$ & $1,020.8$ & 275.7 & 265 & OAA \\
\hline MINUTE STEAK & $11-57-004$ & U11f & 09/12/1969 & $\begin{array}{c}\text { E 595494.8 } \\
\text { N 4081584.4 }\end{array}$ & $<20$ & $1,034.2$ & 277.4 & 265 & OAA \\
\hline NEW POINT & $11-57-002$ & U11c & 12/13/1966 & $\begin{array}{c}\text { E 594655.9 } \\
\text { N } 4081579.7\end{array}$ & $<20$ & $1,030.5$ & 559.3 & 239 & OAA \\
\hline PIN STRIPE & $11-57-001$ & U11b & 04/25/1966 & $\begin{array}{c}\text { E 594386.2 } \\
\text { N } 4082708.0\end{array}$ & $<20$ & $1,093.0$ & 298.7 & 296 & TM-LVTA \\
\hline
\end{tabular}

Source: NNES, 2010b

a DOE/NV, 2000b

$\mathrm{AA}=$ Alluvial aquifer

amsl = Above mean sea level

$\mathrm{HSU}=$ Hydrostratigraphic unit

$\mathrm{m}=$ Meter
NAD = North American Datum

$\mathrm{OAA}=$ Older alluvial aquifer

TM-LVTA $=$ Timber Mountain lower vitric-tuff aquifer

UTM = Universal Transverse Mercator

\section{UNCONTROLLED When Printed}




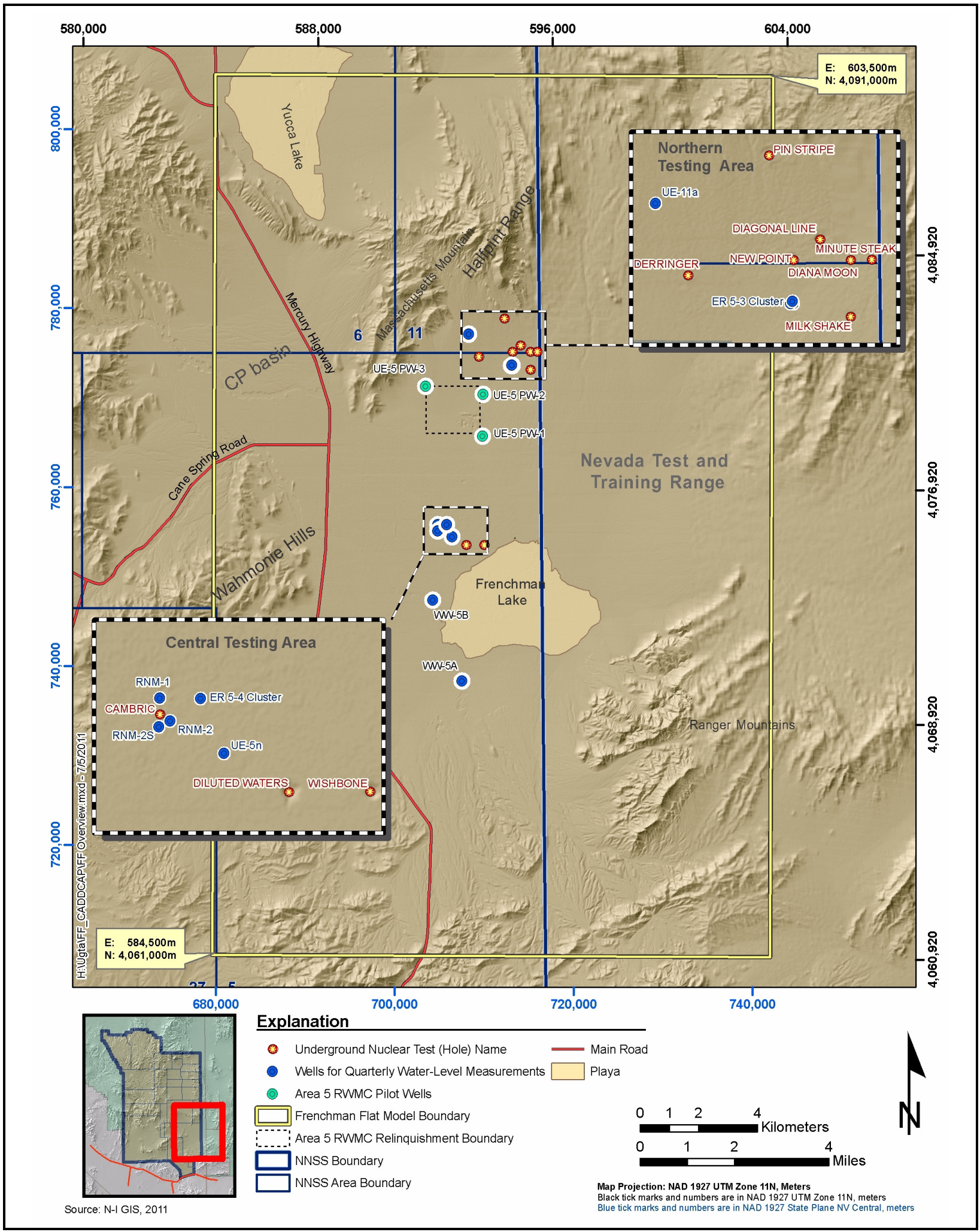

Figure 1-2

Location of Underground Nuclear Tests and Wells in Frenchman Flat 
Until recently, the Frenchman Flat CAU consisted of 11 corrective action sites (CASs); the 11th CAS, CAS 05-20-02, was associated with contamination from the CAMBRIC radionuclide migration (RNM) experiment. This CAS, recently transferred to CAU 106, is associated with the potential surface and near-surface contamination from the experiment. Groundwater contamination resulting from this experiment is addressed under CAS 05-57-003 (Table 1-1). The CAMBRIC RNM experiment was initiated in 1974 to provide data on the migration of radionuclides away from the site of the CAMBRIC underground nuclear test. One well drilled in support of the RNM experiment, RNM-1, was slant-drilled through the radioactive debris and cavity formed by the CAMBRIC test (Figure 1-2). Another well, RNM-2S, was installed $91 \mathrm{~m}$ south of the center of the CAMBRIC working point. Groundwater flow from the working point was induced by pumping Well RNM-2S (Bryant, 1992). Approximately $1.7 \times 10^{7}$ cubic meters of water were discharged during this 16-year experiment into an unlined discharge ditch used to transport the water to Frenchman Lake. Radionuclides discharged into the unlined discharge ditch infiltrated through the unsaturated zone into the groundwater and were detected in samples collected at Wells RNM-2S and UE-5n (Figure 1-2) (Tompson et al., 2002; Rose et al., 2004).

The Area 5 Radioactive Waste Management Complex (RWMC) is also located within this CAU (Figure 1-2). Low-level radioactive waste generated at the NTS/NNSS has been disposed at the RWMC since 1961 and from offsite DOE generators since 1978 (NSTec, 2008). Waste at the RWMC is buried in pits and trenches and is not expected to represent a threat to groundwater over 1,000 years (Shott et al., 1998; BN and Neptune, 2006). The RWMC, which operates under DOE and state Resource Conservation and Recovery Act (RCRA) permit requirements, will be included in the corrective action decisions associated with the Frenchman Flat CAU (Appenzeller-Wing, 2009).

\subsection{UGTA Purpose}

The primary purpose of the UGTA Sub-Project is to define perimeter boundaries for each CAU over the next 1,000 years that enclose areas potentially exceeding the radiological standards of the Safe Drinking Water Act (SDWA) (CFR, 2010). The primary method to define these boundaries is by developing and evaluating flow and contaminant transport models that forecast the extent of potentially contaminated groundwater. The flow and contaminant transport models are used to forecast contaminant boundaries for each CAU that enclose areas potentially exceeding the SDWA 
radiological standards over the next 1,000 years. Contaminant boundaries are not discrete forecasts of the location or concentration of contaminants, but instead are spatial representations of the probability of exceeding the radiological standards. Assessments of the contaminant boundary forecasts are used to aid in identifying UR boundaries for each CAU (FFACO, 1996; as amended).

\subsection{Corrective Action Strategy}

The UGTA strategy, defined in Appendix VI of the FFACO (1996, as amended), assumes that active remediation is not feasible with current technology. As a result, the corrective action for each CAU is expected to be based on a combination of characterization and modeling studies, monitoring, and institutional controls. This approach is consistent with guidance on the use of models in environmental regulatory decision making (NRC, 2007; EPA, 2009). The strategy is implemented through a four-stage approach that comprises the following: (1) Corrective Action Investigation Plan (CAIP), (2) Corrective Action Investigation (CAI), (3) CADD/CAP, and (4) Closure Report (CR) stages (Figure 1-3).

The first two stages of the strategy have been completed for the Frenchman Flat CAU. A value of information analysis (VOIA) was performed and documented (IT, 1997), and a CAIP (DOE/NV, 1999) was developed during the CAIP stage. During the CAI stage, a CAIP addendum (NNSA/NV, 2001) was developed, and the data-collection and evaluation activities proposed in the CAIP and addendum were completed. An external peer review of the resultant groundwater flow and contaminant transport model was completed (N-I, 2010), and the model was accepted by NDEP to allow advancement to the CADD/CAP stage (see Appendix B).

The CADD/CAP stage begins with NNSA/NSO and NDEP identifying and negotiating initial UR boundaries and CAU regulatory boundary objectives. Regulatory boundary objectives are statements of specific objectives to protect the public and environment from exposure to contaminated groundwater (FFACO, 1996; as amended). Also, corrective actions are described and implementation of the corrective action is planned at the beginning of the CADD/CAP stage. The corrective action "Closure in Place with Modeling, Monitoring and Institutional Controls" (FFACO, 1996; as amended) is carried out during both the CADD/CAP and CR stages. The CADD/CAP stage focuses on model evaluation to ensure that existing models provide adequate guidance for the regulatory decisions regarding monitoring and institutional controls. Data-collection 


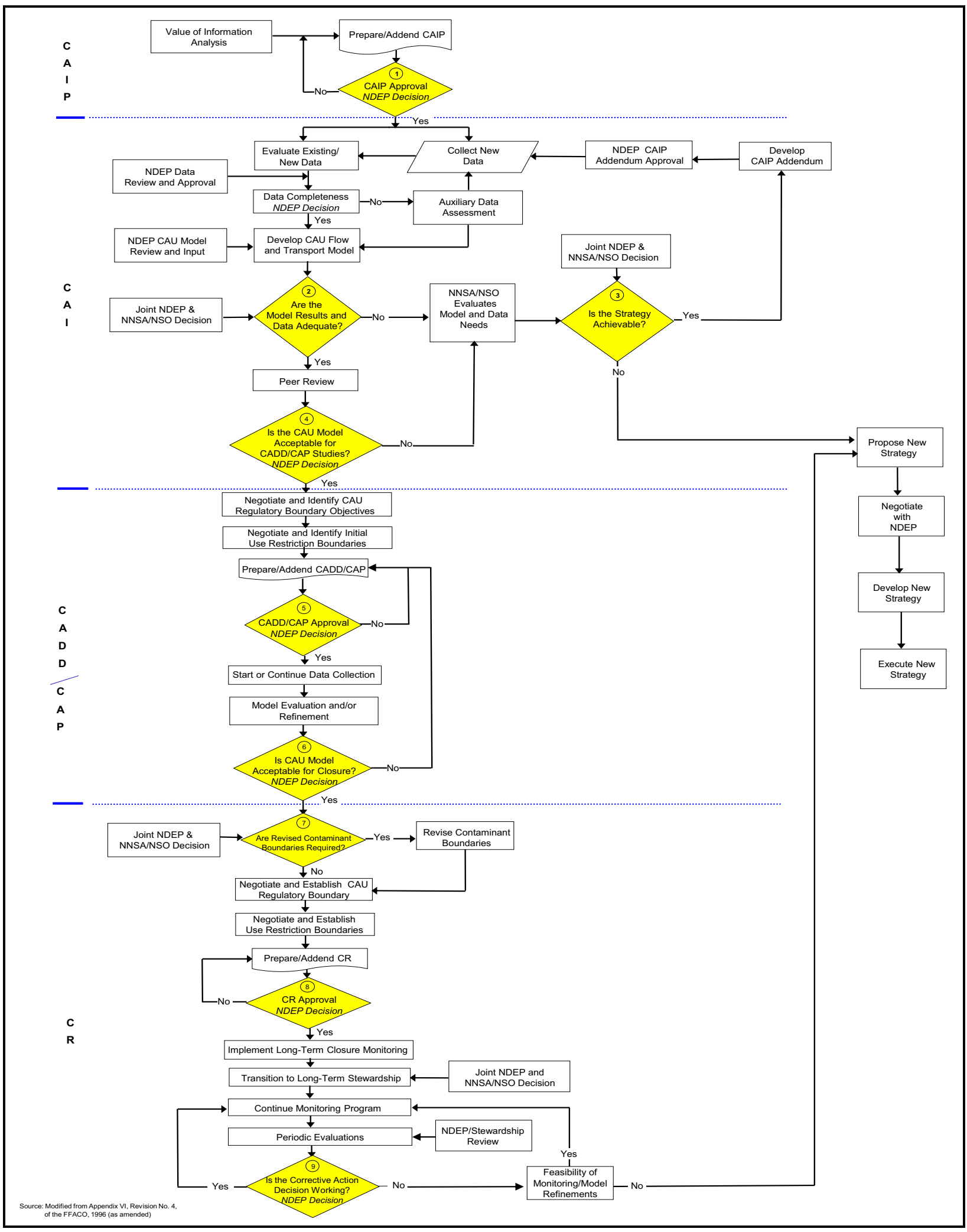

Figure 1-3 UGTA Strategy Flowchart 
activities are identified and implemented to address key uncertainties in the flow and contaminant transport models (Figure 1-3). During the CR stage, final UR boundaries and CAU regulatory boundaries are negotiated and established, a long-term closure monitoring program is developed and implemented, and the approaches and policies for institutional controls are established and implemented.

This CADD/CAP presents a summary of the data-collection and modeling activities performed during the CAI stage (Section 2.0), the corrective action objectives and the corrective action alternative recommended to meet these objectives (Section 3.0), and the implementation plan for the recommended alternative (Section 4.0). References are provided in Section 5.0. 


\subsection{Corrective Action Investigation Summary}

This section summarizes the activities performed during the CAIP and CAI stages of the UGTA strategy for the Frenchman Flat CAU. These stages, encompassing a period of 11 years, were accomplished through two phases. A CAIP approved in 1999 by NDEP (DOE/NV, 1999) provided data-collection and modeling guidelines for the Phase I CAI for Frenchman Flat. Although the CAIP was completed in 1999, investigations of the geology and hydrogeology of Frenchman Flat and the surrounding region have been performed since the early 1950s (see SNJV, 2004c and 2005b and c, for a summary of these investigations).

The Phase I CAI included hydrologic and transport data compilation, analysis, and model development. The assumption was made that no new site characterization data would be collected before groundwater flow and contaminant transport modeling. The Phase I CAI was completed in 1999. The following documents present the results:

- Groundwater Flow Model Documentation Package (Phase I Data Analysis Documentation, Volume VI) (IT, 1996)

- Evaluation of the Hydrologic Source Term from Underground Nuclear Tests in Frenchman Flat at the Nevada Test Site: The CAMBRIC Test (Tompson et al., 1999)

- Underground Test Area Project Corrective Action Unit 98: Frenchman Flat Data Analysis Task, Volume III-Groundwater Flow and Contaminant Transport Model Data Documentation Package (IT, 1999b)

After completing and documenting the Phase I work, comprehensive internal and external peer reviews were conducted. The findings of the external peer review are documented in External Peer Review Group Report on Frenchman Flat Data Analysis and Modeling Task, Underground Test Area Project (IT, 1999a). The reviewers identified some issues relating to data insufficiency and modeling process inadequacy.

An internal review was also conducted, and the results are documented in Lessons Learned from the Frenchman Flat Corrective Action Groundwater Flow and Radionuclide Transport Model (IT, 2000). This lessons-learned document concluded that the Phase I Frenchman Flat CAU model was a good first model of groundwater flow and radionuclide transport at the CAU scale. The review team 
determined that the modeling successfully represented the flow system as defined by the conceptual model and forecasted limited radionuclide travel distances; however, it did not include an assessment of alternative model components and their uncertainty, thus needed refinement.

In 2001, an addendum to the CAIP (NNSA/NV, 2001) was approved by NDEP. Data-collection activities for the Phase II CAI were proposed, and the associated scientific objectives were developed; these activities and objectives are summarized in Table 2-1. These activities include the following:

- Hydrogeologic investigation of the underground testing areas

- Aquifer testing

- Isotopic and geochemistry-based investigation

- Integrated geophysical investigation

A specific objective of the Phase II CAI activities was to measure parameters governing potential vertical flow from the alluvial aquifer (AA) to the lower carbonate aquifer (LCA) to assess the potential for vertical migration from the contamination sources located in the alluvial and volcanic units to the LCA (NNSA/NV, 2001). A modified modeling approach was also included in the CAIP addendum that included the following:

- Development of a total-system model

- Potential verification of the Phase I groundwater flow and transport model

- Potential development of local groundwater flow and transport models

- Sensitivity and uncertainty analyses

- Potential revision of the Phase I groundwater flow and transport model

The Phase II CAI activities were completed in 2010, and a review of the Phase II groundwater flow and contaminant transport models was conducted by an external peer review committee (N-I, 2010). The Phase II CAI activities and resulting contaminant boundaries are presented in Sections 2.1 through 2.3; the results and recommendations of the external peer review committee are presented in Section 2.4; and the conditions of model acceptance by NDEP are presented in Section 2.5.

\subsection{Data-Collection Activities}

The Phase II data-collection activities were performed according to the UGTA Quality Assurance Project Plan (QAPP) (NNSA/NV, 2003). The UGTA QAPP provides the overall quality assurance 
Table 2-1

\section{Data-Collection Activities Performed during the Phase II CAI}

(Page 1 of 2)

\begin{tabular}{|c|c|c|}
\hline \begin{tabular}{|c} 
Scientific Objectives Presented \\
in NNSA/NV (2001)
\end{tabular} & Activities Performed during Phase II CAI & Documents Produced for Activities \\
\hline \multicolumn{3}{|c|}{ Hydrogeologic Investigation of the Underground Testing Areas } \\
\hline $\begin{array}{l}\text { - Characterize the geology of the area } \\
\text { located in the vicinity of the wells at } \\
\text { depth or to the LCA, if practical. } \\
\text { Characterization includes identifying } \\
\text { the stratigraphic unit present; and } \\
\text { determining its physical nature, } \\
\text { thicknesses, structure, and } \\
\text { hydrogeologic and } \\
\text { mineralogic properties. } \\
\text { - Provide borehole geologic and } \\
\text { geophysical information. } \\
\text { - Improve the understanding of vertical } \\
\text { hydraulic gradients within the AA and } \\
\text { between the various HSUs in the } \\
\text { vicinity of the underground testing } \\
\text { areas of Frenchman Flat. } \\
\text { - Characterize groundwater } \\
\text { geochemistry at the water table, near } \\
\text { the base of the alluvium, and at depth } \\
\text { or to the LCA, if practical. }\end{array}$ & $\begin{array}{l}\text { - Five new wells were completed, three in central (ER-5-3, ER-5-3\#2, and } \\
\text { ER-5-3\#3) and two in northern (ER-5-4 and ER-5-4\#2) Frenchman Flat. } \\
\text { These wells better document the stratigraphy and depth to the LCA for the } \\
\text { testing area. } \\
\text { - Petrographic, mineralogic, and chemical analyses of drill cuttings and } \\
\text { sidewall samples were performed to aid in stratigraphic and mineral } \\
\text { alteration characterization. } \\
\text { - Geophysical logging was performed to characterize the lithology, structure, } \\
\text { and water content of the rocks. } \\
\text { - Flowmeter data-along with temperature, electrical conductivity, and pH } \\
\text { measurements-were used to characterize borehole fluid variability and } \\
\text { flow zones. } \\
\text { - Water levels at the ER-5-3 well cluster show that vertical gradients within } \\
\text { the upper portion of the basin-fill units are small; a measured 7-m head } \\
\text { drop between the volcanic aquifer and the LCA indicates that thick } \\
\text { confining units provide hydraulic separation between shallow aquifers and } \\
\text { the LCA. Deeper head measurements in confining units underlying } \\
\text { basin-fill units at ER-5-4\#2 indicate that downward drainage from the } \\
\text { alluvium to the LCA is prohibited. } \\
\text { - Groundwater samples were analyzed for a comprehensive suite of } \\
\text { chemical analytes. } \\
\text { - Hydraulic-head distribution contour maps were developed, aquifers were } \\
\text { identified and their extents delineated. }\end{array}$ & $\begin{array}{l}\text { - Completion Report for Well Cluster ER-5-3 (NNSA/NSO, 2005a) } \\
\text { - Completion Report for Well Cluster ER-5-4 (NNSA/NSO, 2005b) } \\
\text { - Alluvial Layering and Distribution of Reactive Phases within Drill Holes } \\
\text { ER5/4 and UE5N of Frenchman Flat (Warren et al., 2002) } \\
\text { - Letter Report: Analysis of Hydraulic Conductivity and Fracture } \\
\text { Porosity in ER-5-3\#2 and ER-5-4\#2 Based on Fracture Data from } \\
\text { Borehole Image Logs with Implications for the Tuff Confining Unit Flow } \\
\text { Framework, Nevada Test Site, Nevada (SNJV, 2005a) } \\
\text { - Geostatistical Analysis of Spatial Variability of Mineral Abundance and } \\
K_{d} \text { in Frenchman Flat, NTS, Alluvium (Carle et al., 2002) } \\
\text { - Underground Test Area Fracture Analysis Report for Frenchman Flat } \\
\text { Well Clusters ER-5-3 and ER-5-4, Nevada Test Site, Nevada } \\
\text { (SNJV, 2005d) } \\
\text { - Letter Report: Hydraulic Conductivity Profile with Depth for Monitor } \\
\text { Wells ER-5-3, ER-5-3 \#2, and ER-5-4 (Oberlander, 2001) } \\
\text { - Letter Report: Hydraulic Conductivity Profile with Depth for } \\
\text { Well ER-5-4 \#2 (Oberlander, 2003) } \\
\text { - Groundwater Flow Systems at the Nevada Test Site, Nevada: } \\
\text { A Synthesis of Potentiometric Contours, Hydrostratigraphy, and } \\
\text { Geologic Structures (Fenelon et al., 2010) }\end{array}$ \\
\hline \multicolumn{3}{|c|}{ Aquifer Testing } \\
\hline $\begin{array}{l}\text { - Estimate horizontal hydraulic } \\
\text { conductivities in the AA. } \\
\text { - Estimate storage coefficients for } \\
\text { the AA. } \\
\text { - Estimate vertical hydraulic } \\
\text { conductivities within the AA, } \\
\text { if possible. }\end{array}$ & $\begin{array}{l}\text { - Single-well tests were performed to measure hydraulic properties, including } \\
\text { hydraulic conductivities, in the OAA and Timber Mountain welded-tuff } \\
\text { aquifer (TM-WTA) at ER-5-3, LCA at ER-5-3\#2, AA at ER-5-4, and lower } \\
\text { tuff confining unit (LTCU) at ER-5-4\#2. } \\
\text { - Multiple-well aquifer tests (MWATs) were performed at ER-5-3 well cluster. } \\
\text { - An MWAT at RNM-2S (also referred to as the ER-5-4 MWAT) was } \\
\text { performed. The magnitude and direction of hydraulic gradient in the AA } \\
\text { were evaluated between nine wells in the cluster completed in the AA. The } \\
\text { vertical hydraulic gradient was measured between two zones of ER-5-4. } \\
\text { - Tests using well pairs WW-5A and WW-5C, and WW-4 and WW-4a } \\
\text { were performed. }\end{array}$ & $\begin{array}{l}\text { - Interpretation of Hydraulic Test and Multiple-Well Aquifer Test Data at } \\
\text { Frenchman Flat Well Cluster ER-5-3 (SNJV, 2004b) } \\
\text { - Integrated Analysis Report for Single-and Multiple-Well Aquifer } \\
\text { Testing at Frenchman Flat Well Cluster RNM-2s, Nevada Test Site, } \\
\text { Nevada (SNJV, 2004a) } \\
\text { - Integrated Data Report for the Multiple-Well Aquifer Test at Frenchman } \\
\text { Flat Well Cluster ER-5-3 (IT, 2002) } \\
\text { - "Aquifer Test-Analysis of Multiple-Well Aquifer Test RNM-2s, } \\
\text { Frenchman Flat, Nevada" (Pavelko and Halford, 2004) } \\
\text { - "Ground Water-Approval of Aquifer-Test Results; for Test Well WW-5C } \\
\text { Alluvial-Fill Aquifer, in Area 5, Nevada Test Site, Nye County, Nevada" } \\
\text { (Halford, 2003) } \\
\text { - "Ground Water-Approval of Aquifer-Test Results; for Test Well WW-4A } \\
\text { Welded-Tuff Aquifer, in Area 6, Nevada Test Site, Nye County, Nevada" } \\
\text { (Halford, 2002) }\end{array}$ \\
\hline
\end{tabular}

\section{UNCONTROLLED When Printed}


Table 2-1

\section{Data-Collection Activities Performed during the Phase II CAI}

(Page 2 of 2)

\begin{tabular}{|c|c|c|}
\hline $\begin{array}{c}\text { Scientific Objectives Presented } \\
\text { in NNSA/NV (2001) }\end{array}$ & Activities Performed during Phase II CAI & Documents Produced for Activities \\
\hline \multicolumn{3}{|c|}{ Isotopic and Geochemistry-Based Investigation } \\
\hline $\begin{array}{l}\text { Provide independent information on } \\
\text { the origin and flow paths of } \\
\text { groundwater through the Frenchman } \\
\text { Flat groundwater flow system, } \\
\text { including vertical groundwater flux } \\
\text { from overlying units to the LCA. } \\
\text { - Provide estimates of groundwater } \\
\text { age and travel times using measured } \\
\text { concentrations of natural tracer } \\
\text { in groundwater. }\end{array}$ & $\begin{array}{l}\text { - Seven wells in Frenchman Flat were sampled and analyzed for a } \\
\text { comprehensive suite of analytes. Data were combined with data from the } \\
\text { new wells and historical data from additional wells in Frenchman Flat and } \\
\text { vicinity. The three conceptual flow models presented in the IT Corporation } \\
\text { (IT) document (IT, 2001)--north-to-south flow, west-to-east flow, and } \\
\text { vertical leakage from the alluvium to the LCA-were evaluated. } \\
\text { - Carbon-14 }\left({ }^{14} \mathrm{C} \text { ) data were used to calculate groundwater ages (residence }\right. \\
\text { times). Inverse geochemical models were developed to investigate the } \\
\text { origin of groundwater at selected wells within the basin. Groundwater } \\
\text { velocities were calculated (based on }{ }^{14} \mathrm{C} \text { ages) between pairs of wells in the } \\
\text { AA that were likely to lie along the same flow path. }\end{array}$ & $\begin{array}{l}\text { - Evaluation of Groundwater Movement in the Frenchman Flat CAU } \\
\text { Using Geochemical and Isotopic Analysis (Hershey et al., 2005) } \\
\text { - Phase II Groundwater Flow Model of Corrective Action Unit 98: } \\
\text { Frenchman Flat, Nye County, Nevada (SNJV, 2006) }\end{array}$ \\
\hline \multicolumn{3}{|c|}{ Integrated Geophysical Investigation } \\
\hline $\begin{array}{l}\text { Determine the depths to the LCA in } \\
\text { the vicinity of the two testing areas. } \\
\text { - Determine the generalized } \\
\text { topography of the LCA surface } \\
\text { beneath the basin, locate major } \\
\text { structures, and obtain a better } \\
\text { estimate of the thickness of the } \\
\text { Tertiary/Quaternary units across } \\
\text { the basin. } \\
\text { - Delineate structures in the vicinity of } \\
\text { the underground testing areas that } \\
\text { might provide vertical pathways from } \\
\text { the alluvial and volcanic units in which } \\
\text { testing was conducted to the LCA. } \\
\text { Structures such as faults or shear } \\
\text { zones may provide such vertical } \\
\text { pathways themselves or do so by } \\
\text { juxtaposing the AA or volcanic aquifer } \\
\text { with the LCA. } \\
\text { - To the extent possible, delineate } \\
\text { stratigraphic units within the alluvial } \\
\text { and volcanic sections, particularly in } \\
\text { the vicinity of the testing areas. }\end{array}$ & $\begin{array}{l}\text { - A three-dimensional (3-D) seismic survey of the two testing areas, analysis } \\
\text { of gravity data using 3-D inversion methods, and a reanalysis of existing } \\
\text { aeromagnetic data were completed. } \\
\text { - Three seismic horizons were mapped and used to delineate the extent, } \\
\text { thickness, and structural orientation of the alluvial and volcanic aquifers } \\
\text { and to improve constraints on the extent and thickness of the tuff and } \\
\text { volcaniclastic confining units. } \\
\text { - Mapping the Paleozoic surface was performed to improve constraints on } \\
\text { the depth to and structural orientation of the LCA. } \\
\text { - The presence of a northwest-striking fault zone that separates the } \\
\text { Frenchman Flat basin proper from a structural platform on the north } \\
\text { was revealed. } \\
\text { - Seismic data in conjunction with drill-hole and outcrop data strongly } \\
\text { suggest that much of the northern structural platform overlies a detachment } \\
\text { fault within the volcanic rocks. } \\
\text { - In the vicinity of the test locations in the Central Testing Area, the LCA is } \\
\text { more than } 1,000 \mathrm{~m} \text { deeper; and in Northern Testing Area, the LCA is about } \\
400 \mathrm{~m} \text { deeper than estimated from the data available during Phase I. }\end{array}$ & $\begin{array}{l}\text { - Preliminary Gravity Inversion Model of Frenchman Flat Basin, Nevada } \\
\text { Test Site, Nevada (Phelps and Graham, 2002) } \\
\text { - A Hydrostratigraphic Framework Model and Alternatives for the } \\
\text { Groundwater Flow and Contaminant Transport Model of Corrective } \\
\text { Action Unit 98: Frenchman Flat, Clark, Lincoln and Nye Counties, } \\
\text { Nevada (BN, 2005) }\end{array}$ \\
\hline
\end{tabular}


program requirements and the general quality practices for UGTA activities. Descriptions of the data-collection activities performed during the Phase II CAI and a list of the associated documents are presented in Table 2-1. The information in Table 2-1 demonstrates that data-collection activities met the Phase II CAI objectives described in the CAIP addendum (NNSA/NV, 2001).

The Phase II data-collection activities and the corresponding data analysis to support groundwater flow and contaminant transport model development are summarized in the following documents:

- Phase II Hydrologic Data for the Groundwater Flow and Contaminant Transport Model of Corrective Action Unit 98: Frenchman Flat, Nye County, Nevada (SNJV, 2004c)

- Phase II Contaminant Transport Parameters for the Groundwater Flow and Contaminant Transport Model of Corrective Action Unit 98: Frenchman Flat, Nye County, Nevada (SNJV, 2005b)

\section{$2.2 \quad$ Modeling Activities}

The Phase II modeling activities were performed according to the UGTA QAPP (DOE/NV, 2003). The modeling activities are presented in seven main documents:

- A Hydrostratigraphic Model and Alternatives for the Groundwater Flow and Contaminant Transport Model of Corrective Action Unit 98: Frenchman Flat, Clark, Lincoln and Nye Counties, Nevada (BN, 2005)

- Phase II Groundwater Flow Model of Corrective Action Unit 98: Frenchman Flat, Nye County, Nevada (SNJV, 2006)

- Addendum to the Phase II Groundwater Flow Model of Corrective Action Unit 98: Frenchman Flat, Nevada Test Site, Nye County, Nevada (SNJV, 2007)

- Unclassified Source Term and Radionuclide Data for Corrective Action Unit 98: Frenchman Flat Nevada Test Site, Nevada (SNJV, 2005c)

- Evaluation of the Non-Transient Hydrologic Source Term from the CAMBRIC Underground Nuclear Test in Frenchman Flat, Nevada Test Site (Tompson et al., 2005)

- Evaluation of the Transient Hydrologic Source Term from the Cambric Underground Nuclear Test in Frenchman Flat, Nevada Test Site (Carle et al., 2007)

- Phase II Transport Model of Corrective Action Unit 98: Frenchman Flat, Nevada Test Site, Nye County, Nevada (NNES, 2010b) 
Consistent with the modeling activities proposed in the CAIP addendum (NNSA/NV, 2001), a total system model was developed during the Phase II CAI stage (NNES, 2010b, Appendix D). The total system model was constructed using the GoldSim software (GoldSim, 2006) and was used to provide a simplified representation of many of the major transport processes. The total system model allowed a more comprehensive assessment of uncertainty in parameters and processes governing transport because of its superior efficiency (i.e., it is easier to construct, easier to change, and faster to run). The groundwater flow and contaminant transport model was built using the Los Alamos National Laboratory (LANL) Finite Element Heat-Mass (FEHM) code (Zyvoloski et al., 1997b) as specified in the Frenchman Flat CAIP addendum (NNSA/NV, 2001). Selection of this code is presented in the CAIP (DOE/NV, 1999) and CAIP Addendum (NNSA/NV, 2001). The FEHM code has been tested extensively as part of the Yucca Mountain Project; code verification is documented in Zyvoloski et al. (1997a and b), Dash et al. (1996), and Reeves et al. (1994). Transport simulations for steady-state groundwater flow were performed using the PlumeCalc code (Robinson and Dash, 2006).

The document Phase II Documentation Overview of Corrective Action Unit 98: Frenchman Flat, Nevada Test Site, Nye County, Nevada (NNES, 2010a) provides an overview of the groundwater flow and contaminant transport modeling activities performed during the Phase II CAI to forecast the contaminant boundaries for the Frenchman Flat CAU. The FFACO-required ensemble of contaminant boundary forecasts is dependent upon the radionuclides present in the source term, the distribution and release of radionuclides resulting from underground nuclear testing, and the longer-term mass transfer processes that redistribute the radionuclides in the subsurface. To address these issues, several site-specific component models are used to inform the integrated contaminant transport model of the Frenchman Flat CAU (Figure 2-1). These models include the following:

- Hydrostratigraphic framework model (BN, 2005), which provides a physical description of the rocks present at the site and also functionally groups rocks into aquifers and confining units, based on rock properties assumed to control hydraulic conductivity.

- Reactive mineral model (NNES, 2010b, Appendix B), which subdivides the reactive mineralogy of the HSUs to enable high resolution assignment of transport properties.

- Groundwater flow model (SNJV, 2006), which provides the magnitude and direction of groundwater flow. The results from this model are used to control the advective transport of radionuclides in the contaminant transport model. 


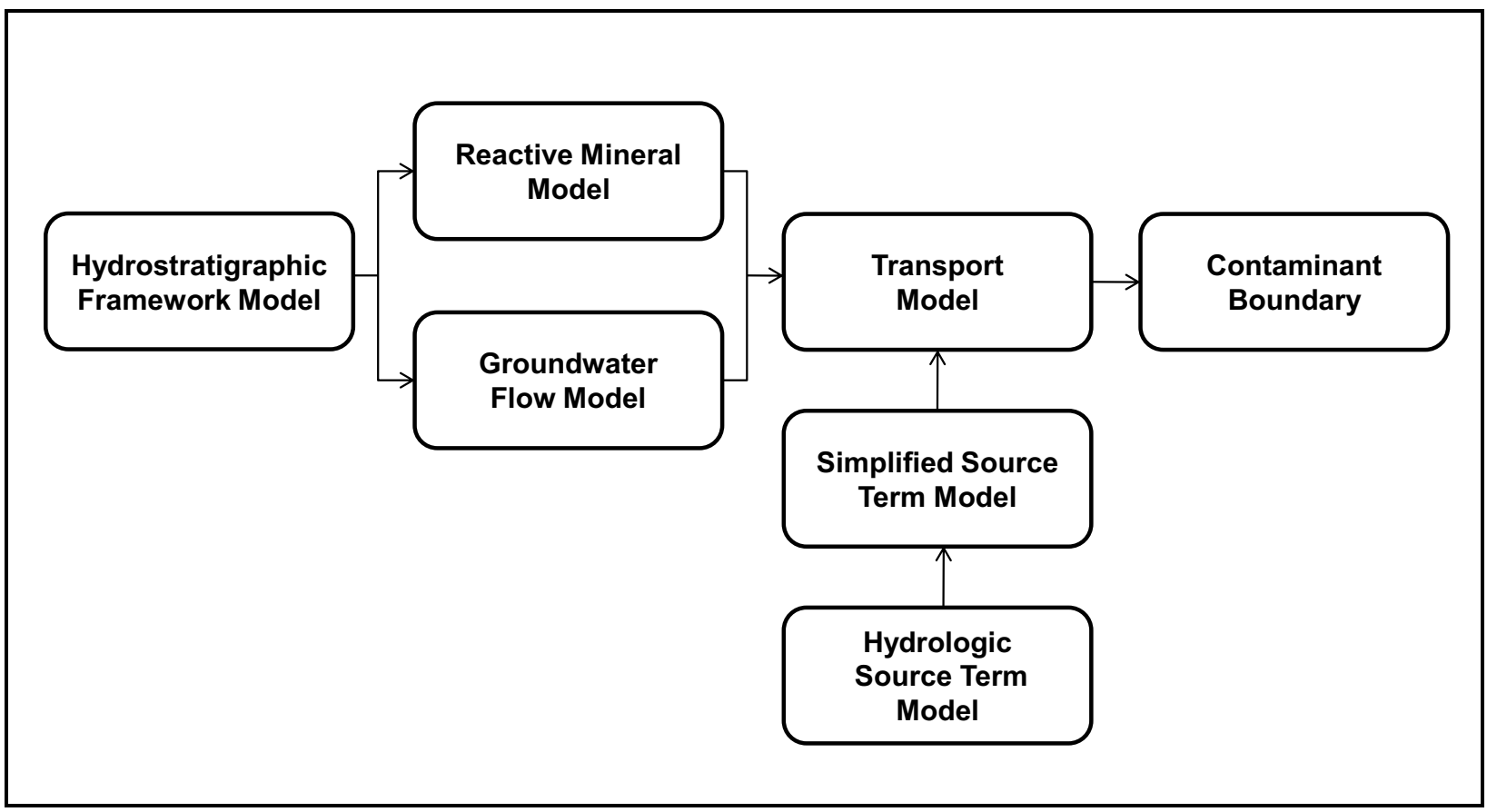

Figure 2-1

Components of the Flow and Contaminant Transport Model

- Hydrologic source term (HST) model (Tompson et al., 2005; Carle et al., 2007), which provides an example in Frenchman Flat of the fundamental processes controlling source term distribution and release near a nuclear test cavity.

- Simplified source term model (SNJV, 2005c), which abstracts the HST model and provides dissolved phase radionuclide mass fluxes from the test cavity for each nuclear test.

- Contaminant transport model (NNES, 2010b), which incorporates the source release functions, transport properties and flow system to provide a representation of probabilistic boundaries of contaminated groundwater.

From these models, a basic conceptual model of contaminant transport was developed. Simply stated, after the radionuclides are distributed throughout the cavity and exchange volume during the test, they are redistributed by flowing groundwater solubilizing the contaminants and transporting them in the subsurface beyond the blast.

The following subsections summarize these component models and present the reports that document their development, evaluation, and results. 


\subsubsection{Hydrostratigraphic Framework Models}

Hydrostratigraphic framework models (HFMs) were developed as the first step in the modeling process; the development and evaluation of the HFMs are documented by Bechtel Nevada (BN) (BN, 2005). The HFMs are constructed using available drill-hole and geophysical data collected in the Frenchman Flat model area along with existing detailed surface geologic data and represent geologic interpretations that honor the data. The Phase II Frenchman Flat HFM model area encompasses more than 570 square kilometers $\left(\mathrm{km}^{2}\right)$ in the southeastern portion of the NNSS (Figure 1-2). The model area has a north-south length of 30 kilometers $(\mathrm{km})$ and an east-west length of $19 \mathrm{~km}$, and includes geologic units as deep as $5 \mathrm{~km}$ below mean sea level.

Five HFMs were developed that include one judged to represent the consensus or most viable integration of data (called BASE) and four alternatives. The HFMs consist of a thick, faulted LCA overlain by volcanic rocks that have been downfaulted during formation of a pull-apart structural basin and buried by alluvium; the Frenchman Flat basin and associated structures are represented in the HFMs by more than 70 faults and 17 HSUs ( 9 aquifers and 8 confining units). The faults considered hydrologically significant (i.e., faults with long traces and/or offsets and faults that are inferred to form significant structural boundaries) were included in the model (BN, 2005). The BASE and alternative HFMs were chosen to represent permissible differences in the geologic conceptualization of the hydrostratigraphic framework consistent with the available data. Each model set is hypothesized to be important to the flow and contaminant transport. Although they differ locally in their detailed representation of the geology, structure, and stratigraphy, the various HFMs integrate a consistent conceptual model for the origin, structure, and large-scale hydrogeologic system of the Frenchman Flat basin (NNES, 2010b). The four alternative HFMs are as follows:

- BLFA - Basalt lava-flow aquifer

- DETA - Detachment fault

- DISP - Displacement fault - aquifer juxtaposition

- $\mathrm{CPBA}-\mathrm{CP}$ thrust fault

The goal of the HFM model development was to incorporate the effects of structural uncertainty identified by the Phase I peer review using alternative models of the hydrogeological framework of the Frenchman Flat basin. By incorporating each alterative framework conceptualization into the 
flow and contaminant transport modeling studies, the structural uncertainty of alternative arrangements of rock units on groundwater flow and transport was investigated.

\subsubsection{Groundwater Flow Models}

The Phase II groundwater flow models are described in three main documents (SNJV, 2006 and 2007; NNES, 2010b) and summarized in the model overview document (NNES, 2010a). The two Stoller-Navarro Joint Venture (SNJV) documents (SNJV, 2006 and 2007) summarize the flow model development and evaluation activities performed early in the modeling process. Subsequent flow model development was performed while developing and evaluating the contaminant transport model and is reported in the Navarro Nevada Environmental Services, LLC (NNES), document (NNES, 2010b).

Multiple discrete calibrations of the UGTA regional model (DOE/NV, 1997b) with specific recharge representations were used to supply the lateral boundary heads and flux targets for the flow model. Three methods were used to estimate precipitation recharge: an empirical mass-balance method and its derivatives (modified Maxey-Eaken [MME]) (Maxey and Eakin, 1949); a deterministic method (U.S. Geological Survey recharge with redistribution [USGSD]) (Hevesi et al., 2003); and a chloride mass-balance method (Desert Research Institute recharge with alluvial mask [DRIA]) (Russell and Minor, 2002). Once available, lateral boundary flows and recharge flux estimates were also obtained from the Death Valley Regional Ground-Water Flow System (DVRFS) model (Belcher et al., 2004).

A flow model consisting of the BASE HFM and USGSD recharge model, designated the BASE-USGSD flow model, was selected to represent the most integrated understanding of the flow system (SNJV, 2006). Net groundwater fluxes calculated by the regional model were used along with 30 hydraulic head measurements for model calibration. Calibration was achieved through a combination of automated parameter estimation using parameter estimation software (PEST) (Doherty, 2008) and manual adjustments to the model parameters guided by iterative sensitivity analyses. The BASE-USGSD model was compared to models that combined the various HFMs and recharge models as well as several alternative approaches to implementing permeability depth decay. The various model combinations were selected to best represent the range of hydrologic and geologic conditions. 
In general, similar flow fields in the testing areas were observed for the multiple alternative models tested. Differences among the models were apparent in the direction of flow in the Northern Testing Area, where flow trajectories ranged from east to southeast to nearly due south. The flow field along the northern edge of the basin in the fractured volcanic rocks (i.e., PIN STRIPE vicinity) was consistently eastward. The largest differences were in the paths starting in the vicinity of PIN STRIPE and MILK SHAKE; the flow paths at PIN STRIPE were sensitive to the direction and magnitude of flow within a narrow band of fractured volcanic rock located along the northern edge of the basin, and the flow paths at MILK SHAKE were sensitive to the local distribution and hydraulic properties of basaltic volcanic rocks. Therefore, the BLFA alternative HFM produced different flow pathways from the MILK SHAKE test cavity.

The Central Testing Area showed considerably less variability in the calibrated flow fields (SNJV, 2007). The flow models testing the application of permeability depth decay result in acceptable calibration statistics, matches to observed permeability values, and flow directions in the vicinity of the underground tests within the range of other calibrated models of the flow system. Because of the thickness of the alluvium and volcanic aquifers, the added process of permeability depth decay did not appear to limit connectivity to the regional groundwater flow system as long as the head gradient between the shallower units and the LCA is maintained.

The BASE-USGSD model was also evaluated using an alternative approach to boundary head assignment and to recharge assignment (NNES, 2010b). The boundary head modification limited changes to boundary heads to specific HSUs along the western edge of the model in the vicinity of CP basin (designated the BASE-USGSD alternative model). An alternative model of recharge in the upland area, north of the saturated alluvial basin, the Northern Hydrologic Alternative (NHA) model, was also developed. For this model, water infiltrating in this upland area travels laterally as saturated, unsaturated, or perched water through the conductive volcanic rocks at the northern edge of the alluvial basin rather than as direct vertical flow from the ground surface to the LCA through a series of permeable rocks underlain by lower-permeability volcanic rocks (NNES, 2010b). The direction and velocity of flow between well pairs computed using geochemical age relationships (SNJV, 2006) were used as two additional observation datasets for the NHA model (NNES, 2010b). These two additional models were considered as part of the ensemble of flow fields for the Frenchman Flat CAU. 
To understand the range of flow model results and determine which models provided similar performance, the concept of "calibration null space" was applied (NNES, 2010b). Moore and Doherty (2005) show that the calibration process can be viewed as subdividing parameter space into two separate subspaces: calibration null space and calibration solution space. Parameter combinations lying within the calibration null space are not informed by the calibration process, while parameters lying within the calibration solution space are informed by the calibration dataset. The nonlinear interaction of flow model parameters within the calibration null space was assessed to capture the parametric uncertainty that allows calibration-insensitive parameters to produce alternative flow fields that may influence transport forecasts, and yet still maintain model calibration. The technique used to produce the flow model realizations of the Frenchman Flat model is the null-space Monte Carlo method available in PEST, version 11 (Doherty, 2008), and described by Tonkin and Doherty (2009). Using this technique, a total of 100 additional calibrated realizations of the groundwater flow system were generated.

\subsubsection{Contaminant Transport Models}

The Phase II groundwater contaminant transport models are described in NNES (2010b). The contaminant transport model integrates a collection of process submodels, often simplified, that simulate radionuclide releases into groundwater at each underground nuclear test. Transport parameters including fracture porosity and aperture, matrix and effective porosity, linear distribution coefficient $\left(\mathrm{K}_{\mathrm{d}}\right)$, and matrix diffusion were assigned distributions based on individual hydrogeologic units that were sampled during Monte Carlo transport simulations. The general guidelines described by Mishra (2002) were followed for assigning probability distributions that capture parametric uncertainty.

The source term modeling began with a steady-state hydrologic source term model of the CAMBRIC test developed by Lawrence Livermore National Laboratory (LLNL) (Tompson et al., 2005). This detailed process model provided concentrations of radionuclides in and away from the CAMBRIC test cavity, taking into account processes that include solute speciation, the rate of dissolution of melt glass, residual test heat, radionuclide desorption from the exchange volume, and radionuclide precipitation and adsorption by minerals in the alluvium. This model was abstracted to develop simplified source term models for the other tests performed in the alluvium within Frenchman Flat 
(SNJV, 2005c). The objective of the simplified models is to capture the important processes and uncertainties of the source-term process models in an efficient computational methodology. The radiologic source term was based on the yield-weighted (DOE/NV, 2000b) average of the total inventory for the 10 underground nuclear tests detonated in Frenchman Flat reported in Bowen et al. (2001). Uncertainty in the radiologic source term is also represented as a multiplicative factor that incorporates the range of inventory uncertainty for the radionuclide types, based on the radiologic source-term uncertainty reported by Bowen et al. (2001). The test-specific parameters that are modified for each test include the test cavity geometry, the size of the exchange volume, radiologic source term, melt glass dissolution parameters, and $\mathrm{K}_{\mathrm{d}} \mathrm{s}(\mathrm{SNJV}, 2005 \mathrm{c})$.

A key control on the release of radionuclides from CAMBRIC is the lower permeability compressed zone - a zone altered by the shock wave from the test - that exists around the cavity. The alteration, thought to depend on the rock, can potentially affect the release of radionuclides from the cavity. In hard rocks, such as granite, lava, and welded tuff, the test shock wave will tend to create zones of enhanced, relative to the native rock, permeability. The CAMBRIC test was conducted in the alluvium; the PIN STRIPE test was conducted in volcanic tuff (TM-LVTA); and the lower fraction of the MILK SHAKE cavity is in basalt lava (BLFA). Because the PIN STRIPE and MILK SHAKE tests likely resulted in significantly different alterations than the CAMBRIC test, simplified process models were constructed for these tests (NNES, 2010b). These process models accounted for unsaturated flow including aqueous radionuclide and tritium $\left({ }^{3} \mathrm{H}\right)$ and ${ }^{14} \mathrm{C}$ gas-phase transport in the vadose zone (to more realistically represent transfer to the saturated zone), and the uncertainty in shock-altered materials (NNES, 2010b). After a series of test calculations which demonstrated the radionuclides that would contribute to the contaminant boundary, a further simplification was made for the contaminant boundary forecasts for MILK SHAKE and PIN STRIPE and all null-space Monte Carlo method simulations. In these cases, only ${ }^{3} \mathrm{H},{ }^{14} \mathrm{C}$, chlorine-36 $\left({ }^{36} \mathrm{Cl}\right)$, iodine-129 $\left({ }^{129} \mathrm{I}\right)$, and technetium-99 $\left({ }^{99} \mathrm{Tc}\right)$ were included in the integrated transport simulations. These beta and photon emitters are present mostly in the rubble outside of the test cavity, where they are readily mobilized by groundwater and subsequently define the contaminant boundary. These species also have limited sorption to the aquifer material. In contrast, alpha emitters and uranium (U) sorb strongly and are found largely in the nuclear melt glass, which must be dissolved before they are released (NNES, 2010b). 
A small-scale model of the Central Testing Area that included the CAMBRIC RNM experiment was constructed as a submodel, paralleling and expanding the scale of a more detailed model of radionuclide release and ditch recirculation conducted by LLNL (Carle et al., 2007). The CAMBRIC RNM experiment generated a significant local transient effect from the withdrawal of water from pumping, and the extraction and subsequent redistribution of radionuclides from Well RNM-2S to groundwater underneath the discharge ditch (Hoffman et al., 1977). This submodel derived hydraulic boundary conditions from the parent steady-state CAU-scale model, and was developed so that it is consistent with the uncertainty analysis required by the FFACO (1996, as amended) and CAIP addendum (NNSA/NV, 2001). Four combinations of HFM and recharge models were selected for development at the sub-CAU scale (SNJV, 2006):

- BASE-USGSD with alternative boundary conditions (or just "alternative")

- BASE-USGSD with no depth decay in AA and OAA permeability

- DISP-USGSD alternative

- CPBA-USGSD alternative

These models were selected because they spanned a range of assumptions regarding the presence and strength of depth decay in the permeability of the AA. Calibration of these transient models was constrained by pumping rates, transient water-level information and tritium breakthrough at UE-5n from the CAMBRIC RNM experiment. The parameters varied during transport forecasts were the transport porosity and the infiltration rate from the ditch into which the RNM-2S flow was discharged. Only the radionuclides found in the RNM-2S discharge $\left({ }^{3} \mathrm{H},{ }^{14} \mathrm{C}\right)$ were used as the source term for the transient model. Steady-state flow simulations were then conducted to extract the cavity flows for use in the simplified source term model. The simplified source term model provided the CAMBRIC nuclear melt glass source (it is assumed, based on RNM-2S data, that the other nuclides were pumped out of the cavity), and the entire WISHBONE and DILUTED WATERS contaminant source.

\subsection{Contaminant Boundaries}

The contaminant boundary is defined by a 5 th percentile likelihood of exceeding the SDWA regulatory standards over 1,000 years (FFACO, 1996; as amended). That is, the area outside the contaminant boundary has only a 5 percent or less chance of exceeding the radiological standards of the SDWA during the next 1,000 years. To compute these probabilities, Monte Carlo simulation is 
used to compute the cumulative distribution function of exceeding the SDWA (Table 2-2). The concentrations of the alpha-, beta- and photon-emitting radionuclides and $U$ are converted to units of picocuries per liter, millirem per year, and micrograms per liter, respectively. For each simulation time, model element, and regulatory group, the values are summed and compared to the SDWA regulatory standards (Table 2-2). If the relative number of exceedances (i.e., relative to the total number of realizations and time increments) is 0.05 or higher, the element is within the contaminant boundary (NNES, 2010b).

Table 2-2

Radionuclide Regulatory Groups

\begin{tabular}{|c|c|c|}
\hline Regulatory Group & Bowen et al. (2001) Radionuclide & Maximum Contaminant Level \\
\hline \hline Beta/Photon Emitter & $\begin{array}{c}{ }^{3} \mathrm{H},{ }^{14} \mathrm{C},{ }^{26} \mathrm{Al},{ }^{36} \mathrm{Cl},{ }^{39} \mathrm{Ar},{ }^{40} \mathrm{~K},{ }^{41} \mathrm{Ca},{ }^{113 m} \mathrm{Cd},{ }^{59 / 63} \mathrm{Ni},{ }^{85} \mathrm{Kr},{ }^{90} \mathrm{Sr}, \\
{ }^{93 \mathrm{~m} / 94} \mathrm{Nb},{ }^{99} \mathrm{Tc},{ }^{107} \mathrm{Pd},{ }^{121 \mathrm{~m} / 126} \mathrm{Sn},{ }^{129},{ }^{135 / 137} \mathrm{Cs},{ }^{241} \mathrm{Pu},\end{array}$ & 4 millirem per year \\
\hline Gross Alpha Particles & ${ }^{150 / 152 / 154} \mathrm{Eu},{ }^{151} \mathrm{Sm},{ }^{166} \mathrm{Ho}$ & 15 picocuries per liter \\
\hline$U$ & All Isotopes & 30 micrograms per liter \\
\hline
\end{tabular}

Source: NNES, 2010b

$\begin{array}{llll}\mathrm{Al}=\text { Aluminum } & \mathrm{Cs}=\text { Cesium } & \mathrm{Ni}=\text { Nickel } & \mathrm{Sr}=\text { Strontium } \\ \mathrm{Am}=\text { Americium } & \mathrm{Eu}=\text { Europium } & \mathrm{Np}=\text { Neptunium } & \mathrm{Th}=\text { Thorium } \\ \mathrm{Ar}=\text { Argon } & \text { Ho }=\text { Holmium } & \mathrm{Pd}=\text { Palladium } & \mathrm{Zr}=\text { Zirconium } \\ \mathrm{Ca}=\text { Calcium } & \mathrm{K}=\text { Potassium } & \mathrm{Pu}=\text { Plutonium } & \\ \mathrm{Cd}=\text { Cadmium } & \mathrm{Kr}=\text { Krypton } & \mathrm{Sm}=\text { Samarium } & \\ \mathrm{Cm}=\text { Curium } & \mathrm{Nb}=\text { Niobium } & \mathrm{Sn}=\text { Tin }\end{array}$

Some radionuclides included in the Bowen et al. (2002) inventory were excluded from the contaminant boundary calculations. Radionuclides with no U.S. Environmental Protection Agency (EPA) dose conversion factor are not addressed by the maximum contaminant level for beta- and photon-emitting radionuclides $\left({ }^{39} \mathrm{Ar},{ }^{41} \mathrm{Ca},{ }^{85} \mathrm{Kr},{ }^{94} \mathrm{Nb},{ }^{107} \mathrm{Pd},{ }^{113 \mathrm{~m}} \mathrm{Cd},{ }^{121 \mathrm{~m}} \mathrm{Sn},{ }^{126} \mathrm{Sn},{ }^{150} \mathrm{Eu}\right.$, and $\left.{ }^{166 \mathrm{~m}} \mathrm{Ho}\right)$. In addition, radionuclides with a low inventory $\left({ }^{26} \mathrm{Al},{ }^{93 \mathrm{~m}} \mathrm{Nb},{ }^{243} \mathrm{Am}\right.$, and $\left.{ }^{244} \mathrm{Cm}\right)$ or that are naturally abundant $\left({ }^{40} \mathrm{~K}\right.$ and $\left.{ }^{232} \mathrm{Th}\right)$ were excluded from the calculations (NNES, 2010b; Pawloski et al., 2001). The excluded radionuclides constitute 220 curies of activity, which is roughly 0.1 percent of the total Frenchman Flat inventory (Bowen et al., 2002).

The contaminant boundaries forecasted by the Phase II groundwater flow and contaminant transport models are presented and evaluated in NNES (2010b) and shown in Figure 2-2. Table 2-3 summarizes the contaminant boundary maximum lateral distance and width for each test. In addition, 


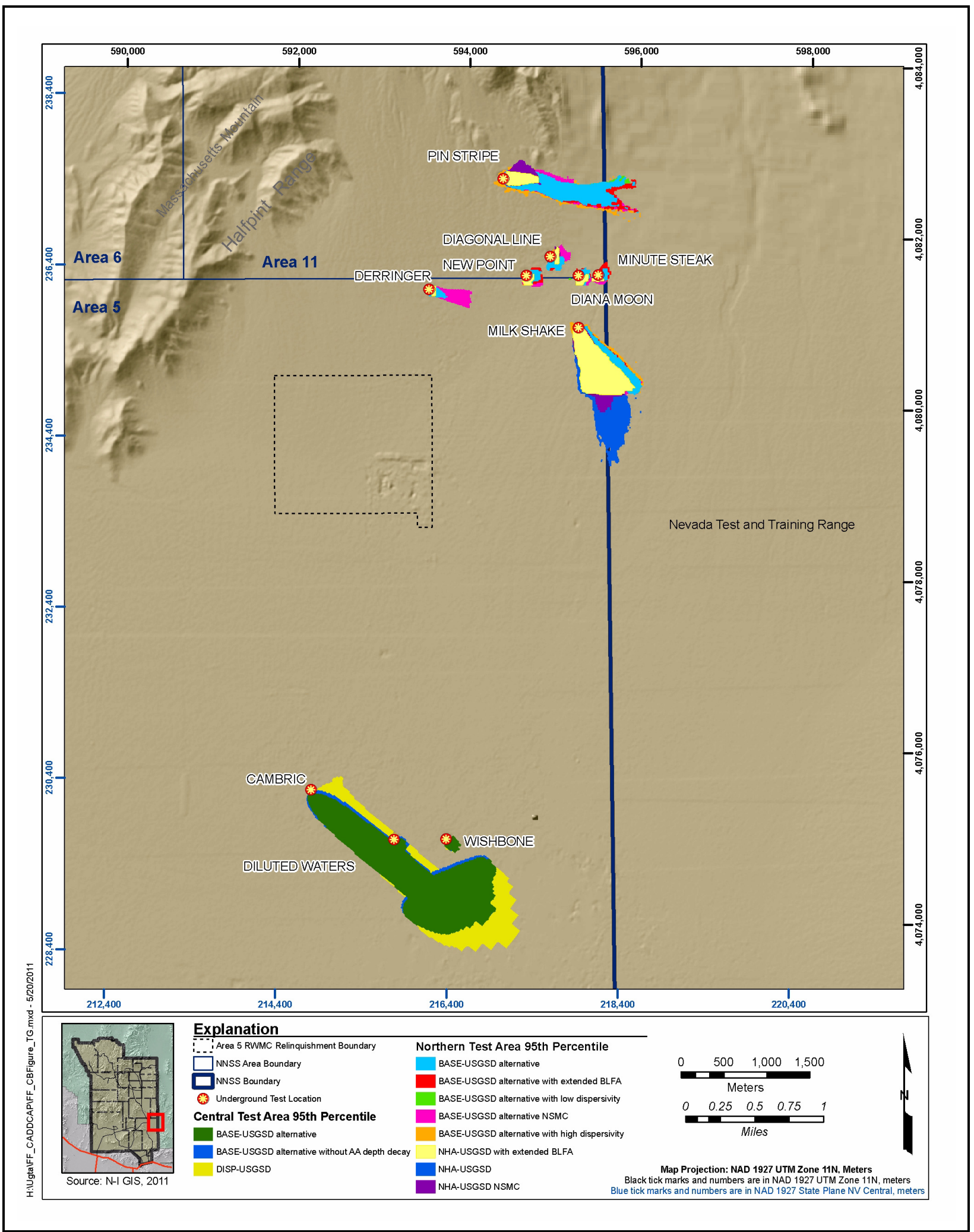

Figure 2-2

Frenchman Flat Contaminant Boundaries

Source: Modified from NNES, 2010b 
Table 2-3

Maximum Saturated Zone Dimensions of Contaminant Boundary for Each Source

\begin{tabular}{|c|c|c|c|c||}
\hline Test & $\begin{array}{c}\text { Maximum } \\
\text { Lateral Distance } \\
(\mathbf{m})\end{array}$ & $\begin{array}{c}\text { Maximum } \\
\text { Vertical Distance } \\
(\mathbf{m})\end{array}$ & $\begin{array}{c}\text { Maximum } \\
\text { Width } \\
(\mathbf{m})\end{array}$ & $\begin{array}{c}\text { Intersected } \\
\text { HSUs }\end{array}$ \\
\hline \hline \multicolumn{5}{|c|}{ Central Testing Area } \\
\hline \hline CAMBRIC & 25 & 30 & 25 & AA \\
\hline CAMBRIC Ditch & 2,860 & 110 & 1,110 & AA \\
\hline DILUTED WATERS & 160 & 45 & 120 & AA \\
\hline WISHBONE & 180 & 30 & 130 & OAA, BLFA \\
\hline \hline \multicolumn{3}{|c|}{ Northern Testing Area } & OAA, BLFA \\
\hline \hline DERRINGER & 500 & 5 & 200 & OAA, BLFA \\
\hline DIAGONAL LINE & 220 & 35 & 200 & OAA, BLFA \\
\hline DIANA MOON & 150 & 30 & 190 & OAA \\
\hline MILK SHAKE & 1,650 & 60 & 625 & OAA \\
\hline MINUTE STEAK & 140 & 35 & 190 & 175 \\
\hline NEW POINT & 180 & 20 & 350 & TM-LVTA, TSA, OAA, LTCU \\
\hline PIN STRIPE & 1,610 & 15 & & \\
\hline
\end{tabular}

Source: Modified from NNES, 2010b

TSA = Topopah Spring aquifer

Table 2-3 summarizes the maximum vertical distance of the contaminant boundary from the water table. A detailed description of these data is presented in NNES (2010b).

\section{Northern Testing Area}

The BASE-USGSD with alternative boundary conditions and the NHA models were selected for contaminant boundary forecasts for the Northern Testing Area based on the flow model evaluations and corroborative data analyses (NNES, 2010b). These models reasonably captured the range of possible advective groundwater flow velocity and directions. The estimated parameter sets for the BASE-USGSD alternative and NHA models were substituted into the BLFA alternative HFM to provide two additional flow models for contaminant boundary forecasts. Similarly, two sets of null-space Monte Carlo method results that addressed parametric uncertainty in the BASE-USGSD with alternative boundary conditions and NHA models were used for contaminant 
boundary forecasts. The impact of dispersivity was also discretely tested for the BASE-USGSD with alternative boundary conditions model by using values lower and higher than used by the original model.

In the Northern Testing Area, the forecasted transport was predominantly horizontal with the majority of the contaminated volume lying within the upper $15 \mathrm{~m}$ of the saturated zone (NNES, 2010b). The water-table elevation is about $730 \mathrm{~m}$ amsl in this area. Two categories of contaminant boundaries are observed for the Northern Testing Area: (1) small boundaries associated with sites where the test cavity and transport are in the OAA, and (2) larger boundaries where the test cavities and/or transport are in fractured volcanic rock (Table 2-3). The simulated transport direction is generally similar in all modeled cases with some variability for the MILK SHAKE contaminant boundary, whereas travel distance is more variable for the PIN STRIPE and MILK SHAKE tests (Figure 2-2).

PIN STRIPE and MILK SHAKE usually have the largest contaminant boundaries and are present in the welded and vitric tuffs at the northern basin edge and BLFA, respectively. The contaminant boundaries of the other tests in the Northern Testing Area are primarily within the OAA. The PIN STRIPE test was conducted in the TM-LVTA, and the contaminants are principally forecasted to migrate eastward in the TSA, the saturated volcanic unit beneath the TM-LVTA. The MILK SHAKE test was performed in the OAA with the contaminants principally forecasted as migrating southeast in the BLFA with some penetration into the alluvium. Contaminants from the PIN STRIPE test are forecast to migrate vertically no more than $15 \mathrm{~m}$ below the water table within 1,000 years as they travel through the TSA; whereas those for the MILK SHAKE test extend to $60 \mathrm{~m}$ below the water table at the cavity and $48 \mathrm{~m}$ at the southern end (NNES, 2010b).

Multiple approaches were used to interpret and quantify the sensitivity of uncertain model parameters on the contaminant boundary forecast (NNES, 2010b). The principal structural uncertainty remaining at the end of the transport modeling is the continuity and lateral extent of the TSA welded tuff at PIN STRIPE and the extent and transport properties of the BLFA at MILK SHAKE (SNJV, 2006; NNES, 2010a and b). The uncertainty is also largely dominated by parameters that impact source release.

The current HFM representation assumes continuity of the thin band of volcanic HSUs, resulting in the narrow flow path along the northern edge of the Frenchman Flat basin. The continuity of the 
TSA, however, could vary from continuous to significantly disrupted by one or more poorly characterized faults within this structurally complex zone. Local-scale models of this fractured rock pathway using alternative geologic interpretations support the inference that the assumption of a lateral-continuous, thin TSA stratigraphic interval in the HFMs is the primary control of simulations that produced the maximum horizontal extent of contaminant boundaries (NNES, 2010b, Appendix D).

The fractured BLFA lies within the alluvial section at or near the water table near the MILK SHAKE test in northern Frenchman Flat. The base HFM depicts the BLFA as three isolated bodies. However, aeromagnetic data, ground magnetic data, and boreholes coverage is insufficient to fully delineate BLFA geometry. Although the uncertain extent of the BLFA is undetectable with the hydrologic data, it has the potential to exercise great control on radionuclide migration from the MILK SHAKE test.

The five beta emitters included in the MILK SHAKE and PIN STRIPE simulations completely reproduced the total forecasted amount of contaminated groundwater for the other five tests conducted in the Northern Testing Area, supporting the exclusion of the other species. For all tests in the Northern Testing Area except MILK SHAKE, the major species contributing to the contaminant boundary, in decreasing order of impact, were ${ }^{3} \mathrm{H},{ }^{14} \mathrm{C},{ }^{36} \mathrm{Cl},{ }^{129} \mathrm{I}$, and ${ }^{99} \mathrm{Tc}$. MILK SHAKE has the same ranking, with the reverse order of ${ }^{14} \mathrm{C}$ and ${ }^{3} \mathrm{H}$. The quick release, high activity, and rapid decay of ${ }^{3} \mathrm{H}$ is apparent before 200 years, after which the longer-lived radionuclides dominate.

\section{Central Testing Area}

Of the four transient groundwater flow models that were calibrated to the RNM-2S MWAT data, only three were carried forward to flow and transport simulations (NNES, 2010b). The CPBA-USGSD model exhibited numerical instability that resulted in prohibitively long computation times. For the three models carried forward, the transport forecast results were nearly identical. Minor differences exist between the contaminant boundaries produced by the three HFMs, with the DISP-USGSD case leading to the largest contaminant boundary. This small difference is likely due to the constraint of calibrating to the RNM-2S MWAT and UE-5n ${ }^{3} \mathrm{H}$ breakthrough (Figure 1-2).

The contaminant boundaries in the Central Testing Area are clearly dominated by the source associated with the ditch infiltration. The infiltration and long-term pumping associated with the 
RNM experiment results in more vertical flow than was seen in the Northern Testing Area (Figure 2-2). Contamination above SDWA maximum contaminant levels due to the CAMBRIC RNM experiment is forecasted to infiltrate below the water table no more than $110 \mathrm{~m}$ within 1,000 years (Table 2-3). The saturated zone has a maximum elevation of about $728 \mathrm{~m}$ amsl in this area. The forecasted contamination from the ditch exceeds the SDWA standard (CFR, 2010) between 1975 and 2015 and disappears by 2115 because most of the source is short-lived ${ }^{3} \mathrm{H}$ (half-life of 12.3 years).

The CAMBRIC, DILUTED WATERS, and WISHBONE tests were conducted in the AA. The CAMBRIC test was the only test at Frenchman Flat to have the working point below the static water table. Contaminants above SDWA maximum contaminant levels from the other tests are forecast to infiltrate within 1,000 years to no more than $45 \mathrm{~m}$ below the water table for DILUTED WATERS and $30 \mathrm{~m}$ below the water table for WISHBONE.

Although the contaminant boundaries account for all regulatory categories, they are dominated by beta and photon emitters (NNES, 2010b). The maximum contaminant level for $U$ is not exceeded. Both alpha emitters and $U$ are found in the nuclear melt glass, which must be dissolved before they can be released to the environment. Dissolution is slow in the Central Testing Area because the cavity flows are low. Beta and photon emitters also have a greater extent than the alpha emitters because of their redistribution as a result of the ditch infiltration.

\subsection{Phase II Peer Review}

An external peer review committee conducted a review of the Phase II groundwater flow and contaminant transport models; the results are documented in External Peer Review Team Report Underground Testing Area Subproject for Frenchman Flat (N-I, 2010). The external peer review provided a technical evaluation of the studies related to the use of models for guiding regulatory decisions and assisted in assessing the readiness of the UGTA Sub-Project to progress to the CADD/CAP stage for the Frenchman Flat CAU. The review committee concluded that the UGTA Sub-Project has explored a wide range of variations in assumptions, methods, and data and that the CAU should proceed to the CADD/CAP stage with an emphasis on model evaluation. 
While the peer review committee found the groundwater modeling and uncertainty analyses quite detailed, the committee did identify some modeling-related issues and recommended that additional studies be considered during the CADD/CAP stage. These recommendations are summarized as follows:

- Evaluate the effects of transient flow conditions on calculated contaminant boundaries, including the effects of long-term declines in water levels, climatic change, and disruption of the groundwater system by potential seismicity (earthquake faulting) along either of the two major controlling fault zones in the flow system (the Cane Spring and Rock Valley faults). Include evaluations of gradient changes in water levels at the Area 5 RWMC pilot wells.

- Evaluate model constraints, including geochemical age-dating data, local-scale variations in hydraulic conductivity, water budgets for the alluvial and upper volcanic aquifer systems in Frenchman Flat, and long-term water-level monitoring with regular measurements of water levels at key monitoring wells.

- Consider modeling approaches in which calculated groundwater flow directions near the water table are not predetermined by model boundary conditions and areas of recharge, all of which are highly uncertain.

- Consider the use of less-complex modeling approaches.

- Evaluate the change in water levels in the vicinity of the Frenchman Flat playa, and develop a conceptual model to explain these water-level changes.

On November 17, 2010, NNSA/NSO submitted a letter to NDEP requesting their approval of the Phase II Frenchman Flat flow and contaminant transport model (Boehlecke, 2010) (see Appendix A). The justification for acceptance of the flow and transport model is presented in Attachment A of this letter, which NNSA/NSO concurred with the recommendations made by N-I. The NNSA/NSO stated that the required changes in the PlumeCalc code will be implemented in model refinements as part of the CADD/CAP studies; the revisions of the model evaluation subsections of Section 3.0 of Appendix VI of the FFACO (1996, as amended) will be completed and submitted to NDEP; and a Model Evaluation Plan will be revised with incorporation of NDEP comments in December 2010, which will be refined until incorporation as an appendix in the CADD/CAP. 
Attachment B of the Boehlecke letter (2010) (see Appendix A) presents a summary of the external peer review comments and the responses by the UGTA Sub-Project. The following actions were proposed to address the recommendations of the external peer review committee:

- A water-level monitoring program for Frenchman Flat will be implemented. The Area 5 RWMC pilot well data will be updated and evaluated with continuing monitoring results.

- Transient conditions and assessment of the effects of future seismic events on groundwater will be considered in consultation with NDEP.

- Progress in development of regional scale climate models for the arid southwest United States will be periodically evaluated and the need for further studies regarding climate changes assessed, in consultation with NDEP.

- Parameters and assumptions that are most representative of the expected case, including assumptions for inflow terms, will be used for modeling when possible.

- Groundwater age information will continue to be assessed.

- Emphasis of data-collection activities will be placed on increasing confidence in model estimations of flow directions. Sites for placement of model evaluation wells will be chosen to explore model results strongly dependent on local directions of groundwater flow and radionuclide transport.

- The potential for local-scale variations in permeability will be considered in evaluations of new data.

- More effective modeling approaches will be considered for CADD/CAP studies, and transparency in communication of modeling results will be emphasized in interactions with NDEP.

\subsection{Model Acceptance}

The Phase II Frenchman Flat flow and contaminant transport model was accepted by NDEP on November 30, 2010, with the following conditions (see Appendix B):

- All actions previously agreed to between NNSA/NSO and NDEP in regards to the revisions to Section 3.0 of Appendix VI of the FFACO (1996, as amended), the Model Evaluation Plan, and corrections to the code errors are completed during the CADD/CAP stage.

- The CADD/CAP will identify actions recommended by the UGTA Sub-Project in response to the peer review comments. The results of these actions must be documented and presented to NDEP via interim documents, letters, or presentations during the CADD/CAP stage. 
The revisions to Section 3.0 of Appendix VI of the FFACO were finalized in May 2011 (FFACO, 1996; as amended). In this revision, changes to the CADD/CAP and CR stages were introduced. Model evaluation became the emphasis of the CADD/CAP stage, and design and implementation of the long-term monitoring program was moved to the CR stage (i.e., once sufficient confidence in the model is achieved). In addition, requirements were added for identifying and negotiating the CAU regulatory boundary objectives and initial UR boundaries in the CADD/CAP stage; and negotiating and establishing final UR and CAU regulatory boundaries in the CR stage. The concept of compliance boundaries was replaced with the UR and CAU regulatory boundaries.

In Attachment A of the Boehlecke letter (2010) (see Appendix A), NNSA/NSO stated that a Model Evaluation Plan was to be developed and included in the CADD/CAP as an appendix. Instead, NDEP and NNSA/NSO agreed for the plan to be included in the body of the CADD/CAP. This condition will therefore be satisfied upon approval of the CADD/CAP by NDEP.

During the final stages of the peer review, an error in one of the codes used for contaminant transport calculations, PlumeCalc, was discovered by the modeling team and brought to the attention of NNSA/NSO, NDEP, and the peer review committee. Identification of the error prompted testing of the code. This code testing will continue throughout the early part of the CADD/CAP stage. The results of the testing will be provided to NDEP through a presentation and a letter report.

A water-level program will be implemented during the CADD/CAP stage (see Section 4.5.3); the data from this program will be evaluated along with Area 5 RWMC pilot well data collected during the same time period. In addition, two new model-evaluation wells are planned for the first iteration of the model evaluation process (see Section 4.5.2). These wells will be located beyond the exchange volumes associated with the PIN STRIPE and MILK SHAKE tests, but close enough to the working point to explore model results strongly dependent on local directions of groundwater flow and radionuclide transport. Groundwater-age information from these wells will be assessed in conjunction with similar information from other wells within Frenchman Flat. The potential for local-scale variations in permeability will also be considered in evaluations of new data. The results will be presented in the Model Evaluation Report (see Section 4.7).

More effective modeling approaches - including using input parameters and assumptions that are most representative of the expected case (e.g., assumptions for inflow terms), and determining 
whether new data indicate that some of the alternative forecasts can be eliminated or given more credence - will be considered for CADD/CAP studies, when possible. Transparency in communication of modeling results will be emphasized during the CADD/CAP stage by identifying key results and clearly documenting the logic of how the studies support the results. Both factors should better demonstrate how complex studies link to CADD/CAP conclusions. Additionally, $\mathrm{CADD} / \mathrm{CAP}$ results will be presented to the pre-emptive review committee (NDEP has an ex-officio member on the committee) and documented in the Model Evaluation Report, and in the final decision by NDEP on whether the CAU will advance to the CR stage or remain in the CADD/CAP stage to collect additional data or refine models.

The need to evaluate non-steady-state conditions and assess seismic events will be considered by the modeling team during both the $\mathrm{CADD} / \mathrm{CAP}$ and $\mathrm{CR}$ stage. The impact of new water-right applications or permits granted in the areas within the UR boundaries and along the projected groundwater flow paths to the regulatory boundary will be evaluated; if necessary, transient analyses will be performed as part of $\mathrm{CR}$ studies. A literature review to evaluate progress in regional-scale climate-model development for the arid southwest United States will be performed during the $\mathrm{CADD} / \mathrm{CAP}$ stage, and the need for further studies regarding climate changes assessed, in consultation with NDEP. The assessments and analyses performed during the CADD/CAP stage, and corresponding results, will be presented in the final Model Evaluation Report prepared before advancing to the $\mathrm{CR}$ stage. 


\subsection{Corrective Action Alternatives}

This section presents the corrective action objectives for the Frenchman Flat CAU and describes the corrective action alternative recommended to meet these objectives.

\subsection{Corrective Action Objective}

The objective of the corrective actions for the Frenchman Flat CAU is to identify the nature and extent of the contamination to ensure the public and the environment are protected from exposure to the contamination.

\subsection{Recommended Corrective Action Alternative}

The recommended corrective action alternative for the Frenchman Flat CAU involves a balance of modeling evaluations, monitoring, and institutional controls. Three assumptions for this alternative are described in the Nevada Test Site Environmental Management End State Vision (DOE, 2006).

First, groundwater technologies for removal or stabilization of subsurface radiological contamination are not cost effective. Second, because of the high remediation costs, closure in place with monitoring and institutional controls is the only likely corrective action. Finally, the important potential risks from radiological contamination of groundwater are to workers, the public, and the environment, and exposure to these risks requires access to groundwater, which can be restricted using institutional controls.

The long-term end state vision for the NNSS is to restore the environment to an extent that will allow the maximum continuation of the national security mission conducted by NNSA/NSO, the national laboratories, and contractors. The end state vision includes cleanup goals that are protective under the planned future uses of the NNSS described in the Final Environmental Impact Statement for the Nevada Test Site and Off-Site Locations in the State of Nevada (DOE/NV, 1996), the Nevada Test Site Resource Management Plan Annual Summary (DOE/NV, 2000a), and Renewal of the Nellis Air Force Range Land Withdrawal Legislature Environmental Impact (DoD, 1999). The vision includes removing only the contamination that poses an unacceptable risk to workers conducting site operations in support of the NNSA/NSO mission, and characterizing or stabilizing the rest of the contamination to ensure that remaining levels do not spread to the surrounding environment and pose 
an unacceptable risk. The near-term vision is to maintain sufficient low-level and mixed low-level radioactive waste disposal capabilities to support accelerated cleanup across the DOE Complex.

The end state for the deep underground radioactive contamination addressed by the UGTA Sub-Project includes developing contaminant boundaries based on the results of the groundwater flow and contaminant transport modeling to define areas that contain water that may be unsafe for domestic and municipal use. A monitoring network will be installed to ensure future protection of the public and the environment. Institutional controls will be continued or enhanced to restrict access to contaminated groundwater; and wells will be monitored, sampled, and refurbished or replaced, as applicable (DOE, 2006). Once the UGTA Sub-Project CAUs are ready for closure (currently planned for fiscal year 2027), responsibilities for long-term stewardship (long-term monitoring and management activities) will be turned over to the landlords, currently the U.S. Air Force (USAF) for the Nevada Test and Training Range (NTTR), and NNSA/NSO for the NNSS. Planning and mitigation strategies are in process and will continue to be implemented to ensure proper stewardship of the remaining contaminated sites to protect workers, the public, and the environment, now and for future generations (DOE, 2006).

Few options are available for remediating groundwater contaminated with radionuclides (Van Deuren et al., 2002). Because radionuclides cannot be destroyed or degraded, applicable remedial approaches are limited to separation, concentration/volume reduction, or immobilization. These approaches require that the resulting wastes be contained and isolated for long periods of time, which increases the risk of exposure. Potential remediation alternatives were previously evaluated by the UGTA Sub-Project (DOE/NV, 1997a). The alternatives evaluated by DOE/NV (1997a) represented presumptive remedies outlined by EPA (1994) including the following:

- No action

- Intrinsic remediation alternative: natural attenuation

- Institutional controls

- $\quad$ Pump and in situ treatment

- Excavation, physical separation/chemical extraction, and onsite disposal

The American Society of Mechanical Engineers and the Institute for Regulatory Science, with the participation of stakeholders, performed a peer review of the UGTA corrective action strategy (ASME/RSI, 2001). With respect to the evaluation of potential remediation alternatives, the peer 
review determined the following: (1) the evaluation of potential alternatives that address the remediation of groundwater contamination was appropriate, given the constraints of the technology and the unique characteristics of the groundwater contamination addressed by the UGTA Sub-Project; (2) based on cost and maintaining radiological exposures as low as reasonably achievable (ALARA), the focused evaluation supported the more passive technologies of intrinsic remediation and institutional controls (i.e., UGTA corrective action strategy); and (3) although no known "breakthrough" technology has been reported in the area of remediation of radionuclide-contaminated groundwater since the evaluation performed by the DOE, Nevada Operations Office (DOE/NV) (1997a), there is a recurrent need for further evaluation of remedial alternatives as new methods are discovered and/or demonstrated to be effective.

As described in FFACO (1996, as amended), NNSA/NSO and NDEP will evaluate technological advances in groundwater remediation during the life cycle of the UGTA Sub-Project, and significant changes in technology and/or the cost of remediation alternatives could lead to a reevaluation of alternatives to the UGTA strategy. At this time, there are no new technologies that warrant such an evaluation. Therefore, the alternative recommended to meet the corrective action objectives identified in Section 3.1 continues to be Closure in Place with Modeling, Monitoring, and Institutional Controls. The three components (model evaluations, monitoring, and institutional controls) planned for the CADD/CAP and CR stages are presented below.

\section{Model Evaluations}

Groundwater flow and contaminant transport model evaluations and possible refinements continue through all stages of the UGTA strategy. During the CADD/CAP stage, contaminant boundary forecasts and model uncertainties, initially developed during the CAI stage, are tested through further data-collection activities. The goal of model evaluation during the CADD/CAP stage is to build confidence that flow and contaminant transport modeling results can be used for the regulatory decisions required for CAU closure. The regulatory decisions include identifying and establishing CAU regulatory objectives and boundaries; identifying institutional controls, including UR boundaries; and developing a long-term closure monitoring program. These decisions are made during the $\mathrm{CADD} / \mathrm{CAP}$ and $\mathrm{CR}$ stages. During the $\mathrm{CR}$ stage, continued model evaluation includes 
evaluating the monitoring results for consistency with the forecasts of contaminant boundaries, and adhering to the UR and regulatory boundaries.

\section{Monitoring}

A long-term closure monitoring program is planned and implemented during the CR stage.

The monitoring plan consists of a groundwater monitoring strategy and describes the implementation of this strategy to ensure compliance with the necessary requirements. This strategy essentially verifies through appropriate monitoring activities that COCs have not exceeded the SDWA (CFR, 2010) at the regulatory boundary and that adequate institutional controls are established and administered. Monitoring for changed conditions (e.g., seismicity, water development) will also be included. The long-term closure monitoring program will include conducting activities such as performing periodic analysis of monitoring results, determining optimum performance indicators, evaluating performance criteria, locating new monitoring wells, and replacing monitoring wells as needed. The monitoring network design includes the technical requirements and physical layout of the well system. The distance between the monitoring well(s) and the UR and regulatory boundaries is predicated on the need to provide adequate early warning. Periodic water sampling of the monitoring well(s) will confirm that UR and regulatory boundaries are sufficient.

\section{Institutional Controls}

Institutional controls limit access to activities in areas of potentially contaminated groundwater by establishing active and/or passive controls. Active institutional controls include controlling site access, performing inspections, and patrolling the area. Passive institutional controls include using land ownership or use requirements; markers; and public records, archives, or other methods of preserving knowledge of a site and its hazards. These controls are monitored on a routine basis, as applicable, to verify performance.

The NNSS encompasses approximately 1,360 square miles of land and is surrounded by the DoD NTTR and unpopulated land controlled by the Bureau of Land Management (BLM). Active and passive institutional controls have been in place at the NTS/NNSS and at NTTR for more than 50 years. The entire perimeter of the NNSS is not fenced, but it is posted as a restricted area and is actively patrolled; access is prohibited except at designated entrances. Access required for exposure 
to a member of the public or inadvertent human intrusion is prohibited by NSO Order 450.XA, Nevada Test Site Access and Area Control (NNSA/NSO, 2006a). Beyond the perimeter, the BLM land and NTTR provide buffer zones of limited access. Barricades and security stations control the few roads that access NNSS boundaries. Inactive facilities and areas that are known to be contaminated and require access control are fenced and posted with warning signs in accordance with the Occupational Radiation Protection standards (CFR, 2011).

The NNSA/NSO provides federal management and oversight for all activities conducted at the NNSS. Controls and URs are considered in accordance with DOE P 454.1, Use of Institutional Controls (DOE, 2003), during the evaluation, siting, and control of projects planned for the NNSS. Projects must justify a need to be within the boundaries of the NNSS. Screening and siting of new projects are controlled by NSO M 412.X-2, Project Screening and Siting Approval Process (NNSA/NSO, 2006b). In addition, all activities performed on the NNSS require a Real Estate/Operations (REOP) permit (NNSA/NSO, 2009a). The REOP process ensures that work performed under NNSA/NSO purview is well defined and has well-defined geographical boundaries; has identified the hazards and has established and implemented controls to mitigate those hazards; is protective of the environment (e.g., includes archaeological survey requirements, land-disturbance minimization, and waste management); is properly authorized; and is managed effectively. The considerable depth to groundwater throughout most areas of the NNSS and vicinity effectively restricts surface exposure to contaminated groundwater to onsite environmental workers via deep drill holes and water wells. In addition, UR boundaries are identified within this CADD/CAP document (see Section 4.1) and established within the CR. Institutional controls associated with the UR boundaries are introduced in Section 4.1. 


\subsection{Implementation of the Corrective Action Plan}

The preferred corrective action alternative will be carried out in two stages (i.e., CADD/CAP and CR stages) within the UGTA strategy (Figure 1-3). This section focuses on implementing the corrective actions associated with the $\mathrm{CADD} / \mathrm{CAP}$ stage and therefore describes the model evaluation process. During this stage, data-collection activities are identified and implemented to address key uncertainties in the flow and contaminant transport models. In addition, the initial UR boundaries and the CAU regulatory boundary objectives are identified and negotiated between NDEP and NNSA/NSO at the start of the CADD/CAP stage. The final UR boundaries and the CAU regulatory boundaries are established and negotiated at the beginning of the CR stage; the CR will document these boundaries. The CR will also describe the long-term closure monitoring program, the approaches and policies for institutional controls, and the transition of the UGTA Sub-Project to long-term stewardship.

\subsection{Use Restriction Boundaries}

The initial UR boundaries for the Frenchman Flat CAU are presented in Figure 4-1. The boundaries are based on the $95^{\text {th }}$ percentile of the contaminant boundary forecasts, worker health and safety requirements, and administrative polices that restrict access (FFACO, 1996; as amended). The final UR boundaries may be based on a different percentile than the $95^{\text {th }}$ percentile of the contaminant boundary forecasts. The UR boundaries surround the forecasted contaminant boundaries and the Area 5 Area-Relinquishment Boundary containing the RWMC (Figure 4-1). The performance assessment and composite analysis for the RWMC showed that transport was insufficient to establish a downward path to groundwater; the only release pathway that allows interaction between the facility inventory and the groundwater is from drilling to groundwater near the facility (Shott et al., 1998; BN and Neptune, 2006).

A UR form and map, the official records documenting sites where contamination remains in place after closure, will be included in the CR. The DOE, BLM, and USAF maintain UR records for as long as the land is under their jurisdiction. The UR will be documented on a UR form and map and filed in the DOE Facility Information Management System (FIMS), the FFACO database, the DOE CAU/CAS files, and the USAF Geographic Information Systems files. 


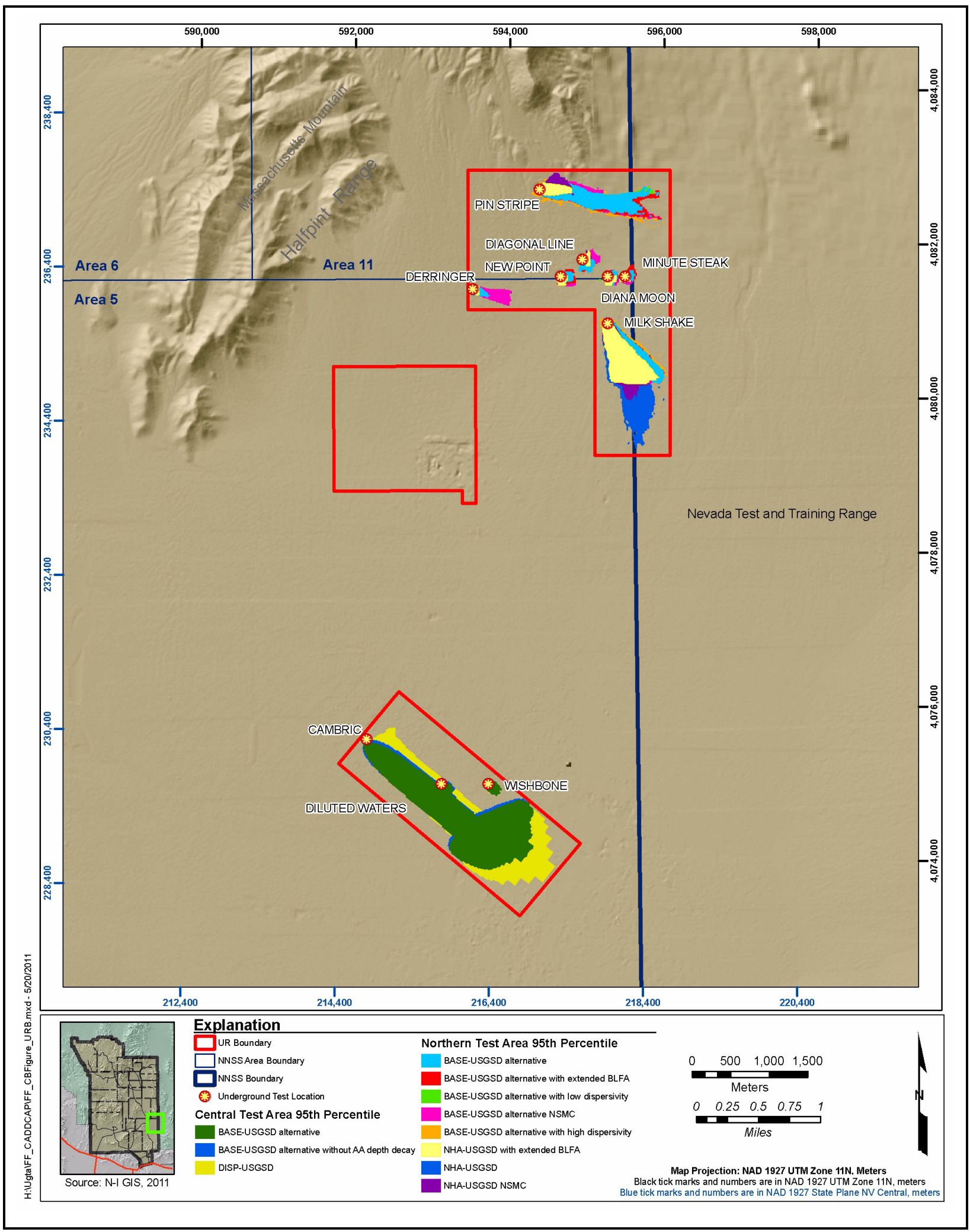

Figure 4-1

UR Boundaries

Source: Modified from NNES, 2010b 
Institutional controls, within the UR boundaries, are required to prevent the use of and exposure to potentially contaminated groundwater for purposes other than environmental investigations. These restrictions are required to protect the public, workers, and environment and also to protect the environmental investigations performed by UGTA to evaluate the conceptual and numerical models of flow and transport. Because the UR boundaries are within the NNSS and NTTR boundaries, URs will primarily be administrative and not require onsite postings or physical barriers other than those already in place for the RWMC, NNSS, and NTTR. Examples of potential institutional controls include the following (DOE, 2005):

- Land-use and real property controls, notifications, and restrictions: All subsurface activities - including drilling, pumping, and testing of wells - shall be communicated to NNSA/NSO before field activities begin. These controls are administered through the screening and siting approval and REOP processes (NNSA/NSO, 2006b and 2009a).

- Groundwater control: Groundwater cannot be used for human consumption such as drinking or irrigating crops. Any industrial use of the groundwater, such as dust control, must be preceded by laboratory analysis for site-related contaminants, and the groundwater must meet SDWA standards (CFR, 2010). These controls are ensured through a series of databases previously described as well as the screening and siting approval and REOP processes (NNSA/NSO, 2006b and 2009a).

- Government ownership: The NNSS and NTTR are federally controlled, secure sites. Identification and records of the restrictions are present in multiple locations under different agencies. Once characterization and remediation work is complete, the remaining monitoring and long-term management activities revert to the respective organizations responsible for ongoing missions (currently DoD for the NTTR and NNSA/NSO for the NNSS). There are no plans to relinquish any land currently under their responsibility (DOE, 2006).

\subsection{CAU Regulatory Boundary Objectives}

The regulatory boundary objective for the Frenchman Flat CAU is to protect receptors downgradient of the Rock Valley fault system from radionuclide contamination. The basis for the objective is that, although contaminants resulting from underground nuclear testing are not forecasted to migrate out of the basin within the next 1,000 years, the Rock Valley fault system is the expected pathway of groundwater flow out of the Frenchman Flat basin (Figure 4-2). This objective and basis will be tested through the process of model evaluation during the CADD/CAP and CR stages of the Frenchman Flat CAU studies. 


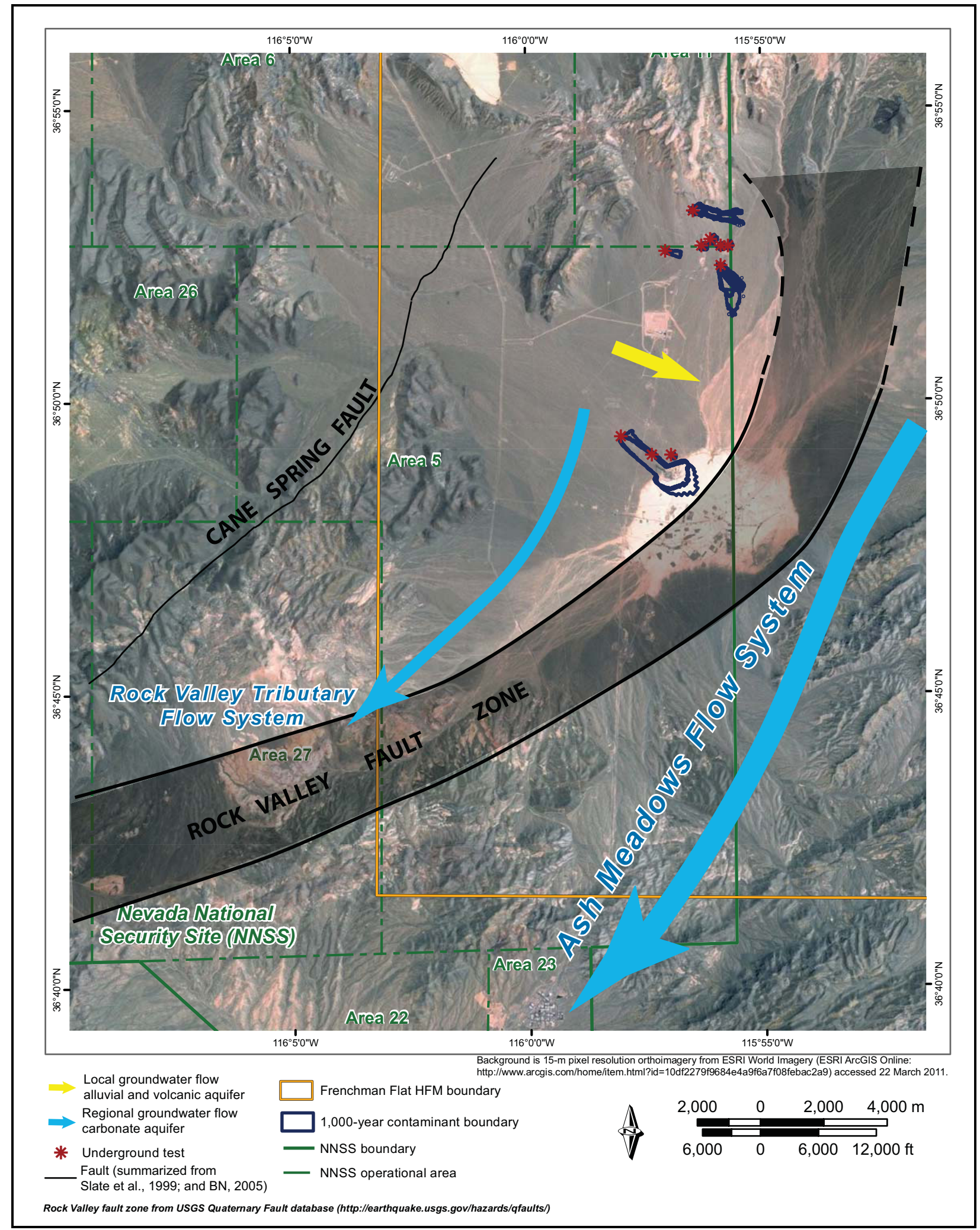

Figure 4-2

Rock Valley Fault System in the Vicinity of Frenchman Flat 


\section{Rock Valley Fault}

Page 41 of 68

The Frenchman Flat basin is located in and extends beyond the southeast part of the NNSS into the NTTR. The geologic, geophysical, and drill-hole data for the Frenchman Flat CAU show the basin is a southeast-tilted, half-graben with the main basin-forming faults located on the southern and eastern basin margins, coinciding with the northeastern projection of the Rock Valley fault system (Figure 4-2) (BN, 2005). This fault system extends from Amargosa Valley on the southwest to southern Frenchman Flat. The Rock Valley fault system is grouped tectonically with multiple northeast-trending left-slip faults that form the Spotted Range-Mine Mountain structural group described by Carr (1984). Local Quaternary fault scarps and clusters of historic earthquakes within and adjacent to the Rock Valley fault system demonstrate that the fault system is presently active (O’Leary, 1996).

The conceptual models for groundwater flow in the Frenchman Flat basin have been developed over multiple decades (Winograd and Thordarson, 1975; Laczniak et al., 1996; Fenelon et al., 2010; NNES, 2010b), culminating with more recent studies associated with the UGTA Sub-Project (Section 2.0). Dominant features of all conceptual models for the Frenchman Flat basin are the high hydraulic heads in the CP basin northwest of Frenchman Flat (over $100 \mathrm{~m}$ higher than heads in the Frenchman Flat basin); the semiperched condition of groundwater in the alluvium and volcanic aquifers with higher heads in these aquifers than the regional LCA; and the documented southeastward thinning of the volcanic section away from volcanic centers located northwest of Frenchman Flat. These combined features support two inferential observations for the basin: (1) groundwater flow in the alluvial and volcanic aquifers is likely horizontal across the Frenchman Flat basin from northwest to southeast, and (2) there is limited leakage downward into the LCA from the alluvium and volcanic aquifers as this section thins to the southeast across the Frenchman Flat basin and/or is offset by faults associated with the Rock Valley fault system. Particle track studies for Frenchman Flat originating at locations of underground tests show southeast flow through the alluvial and volcanic aquifers changing to southwestward flow in the LCA following surface and subsurface faults associated with the basin-forming structure of the Frenchman Flat basin (BN, 2005; SNJV, 2006; NNES, 2010b). These observations are consistent with groundwater flow converging into and following faults of the Rock Valley fault system in southern Frenchman Flat (Figure 4-2). Modeling results show radionuclide transport follows these groundwater flow directions, but only limited 
quantities of contaminants reach the LCA in 1,000 years (NNES, 2010b). Subsequent southwest groundwater flow along the Rock Valley fault system outside of the Frenchman Flat model domain may remain in the Rock Valley tributary flow system of Fenelon et al. (2010) and discharge into the Alkali Flat-Furnace Creek Ranch Flow system (Laczniak et al., 1996, pg. 19; DOE/NV, 1997b; Fenelon et al., 2010, plate 5) and/or may move southward across the Rock Valley fault system and discharge into the Ash Meadows flow system (Figure 4-3).

\subsection{Model Evaluation Purpose}

The model evaluation process, inherent throughout the UGTA strategy, continues during the CADD/CAP stage with an increased focus on assessing the reliability of model results and testing contaminant boundary forecasts through data collection and model refinements. The purpose of the model evaluation process is to develop sufficient confidence in the model for its use in guiding the development of the long-term monitoring network and institutional controls that meet the objectives of site closure.

\subsection{Model Evaluation Approach}

The overall approach to building confidence in the model is fourfold:

- Collection of new information to address key uncertainties

- Evaluation of new data to determine whether they are consistent with the model forecasts

- Review of results by independent scientific experts (i.e., pre-emptive review committee)

- Refinement of the model, if necessary

This approach allows testing the model from multiple perspectives and will be used collectively to build the required confidence in model results to move to the CR stage of the UGTA strategy. Data-collection activities are performed in order to address key uncertainties of the flow and contaminant transport model. Although it is not possible to prove that the model is correct, it is possible to prove that it is not correct through new data collection and analysis. This approach is referred to in the second bullet item above, where consistency of the new data with the model builds confidence in the forecasts. Statistical metrics, where applicable, may be developed to determine the impact of the new data on the model forecasts. Confidence in the model is also built through independent review of data-collection and modeling results by a pre-emptive review committee composed of UGTA participants that are knowledgeable in the hydrogeology, geology, testing history, 


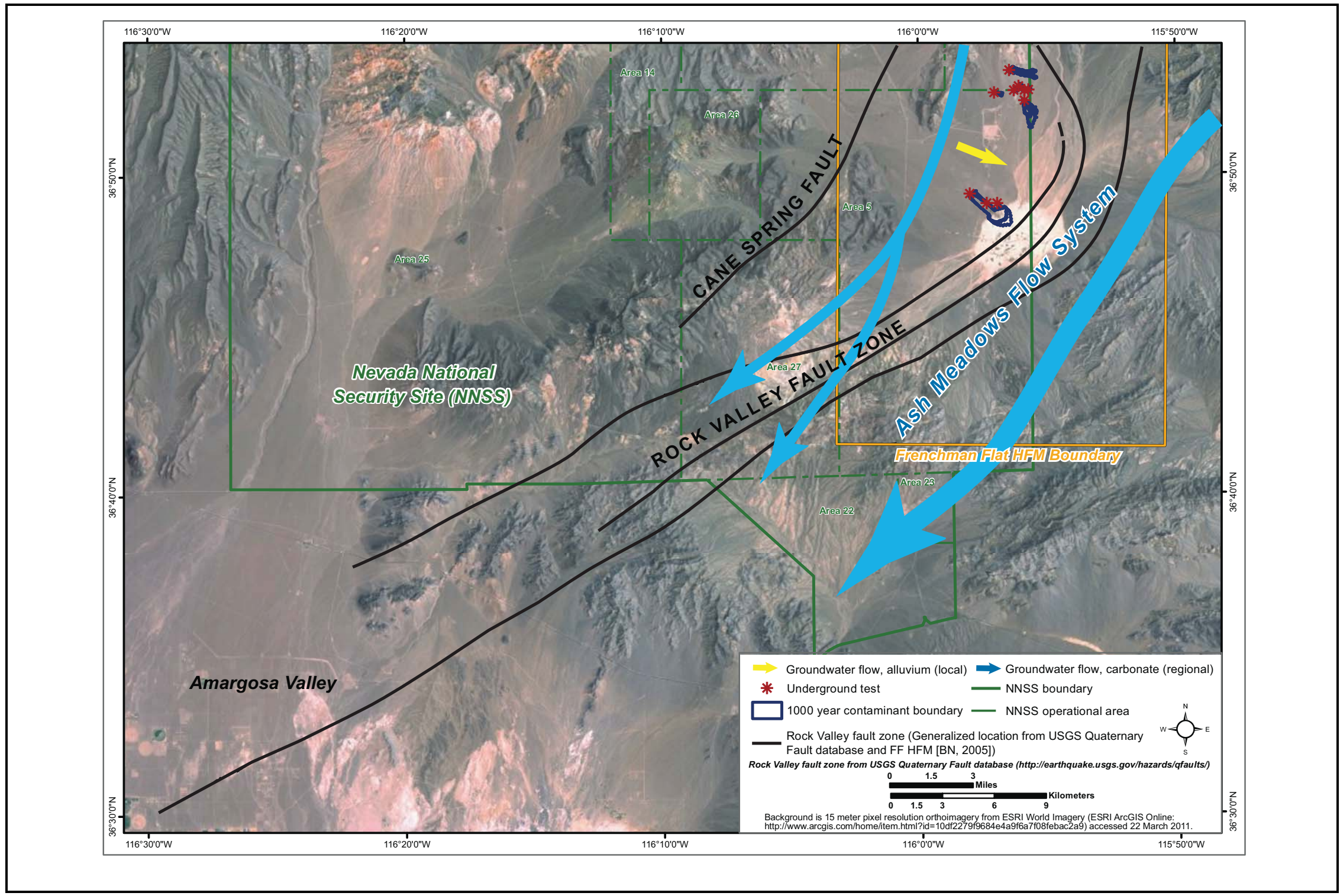

Figure 4-3

Rock Valley Fault System

\section{UNCONTROLLED When Printed}


and radiochemistry of the CAU. The pre-emptive review committee performs technical reviews to assure that work is comprehensive, accurate, in keeping with the state of the art, and consistent with CAU and Sub-Project goals (NNSA/NSO, 2011). The model is refined if the modeling team and pre-emptive review committee determine that the newly collected data are inconsistent with the current model forecasts or that addition of the new data may improve the quality of the model results.

\subsubsection{Model Evaluation Process}

The CADD/CAP model evaluation process consists of an iterative series of five steps designed to build confidence in the site conceptual model and model forecasts (Figure 4-4). Step 1 is associated with identifying data-collection activities and preparing or amending the CADD/CAP. Step 2 is the $5^{\text {th }}$ decision point in the UGTA strategy, NDEP approval of the CADD/CAP (FFACO, 1996; as amended). Data-collection activities are performed in Step 3, and the impact of the new data is assessed in Step 4. Step 4 also includes an iterative process of model refinement, assessments of data and model results, pre-emptive review committee presentations, and report preparation. Completion of Step 4 is achieved once the modeling team (i.e., those performing modeling activities) and pre-emptive review committee agree that further model refinement is not required and a Model Evaluation Report is prepared. Step 4 is concluded either because additional data collection has been determined to be necessary or sufficient confidence in the model exists to recommend advancing to the CR stage, and all the information pertaining to either decision has been fully documented in the Model Evaluation Report. Step 5 is the $6^{\text {th }}$ decision point in the UGTA strategy, NDEP's acceptance of the model for closure (FFACO, 1996; as amended). If NDEP accepts the model for closure, the CAU will proceed to the CR stage, if not, the process returns to Step 1.

\section{Step 1 - Identification of Model Evaluation Targets and Data-Collection Activities}

The CADD/CAP model evaluation process begins with model uncertainty identification and prioritization by the modeling team with the support of others with additional expertise, if necessary. The initial evaluation (i.e., evaluation that follows the CAI stage) begins with an assessment of the model uncertainties identified in the contaminant transport model report. The uncertainties are identified by sensitivity and uncertainty analyses, including evaluation of alternative conceptual models. A list of model evaluation targets is developed for the key uncertainties, and data-collection activities are identified that could best address those targets. The selection is based on the potential 


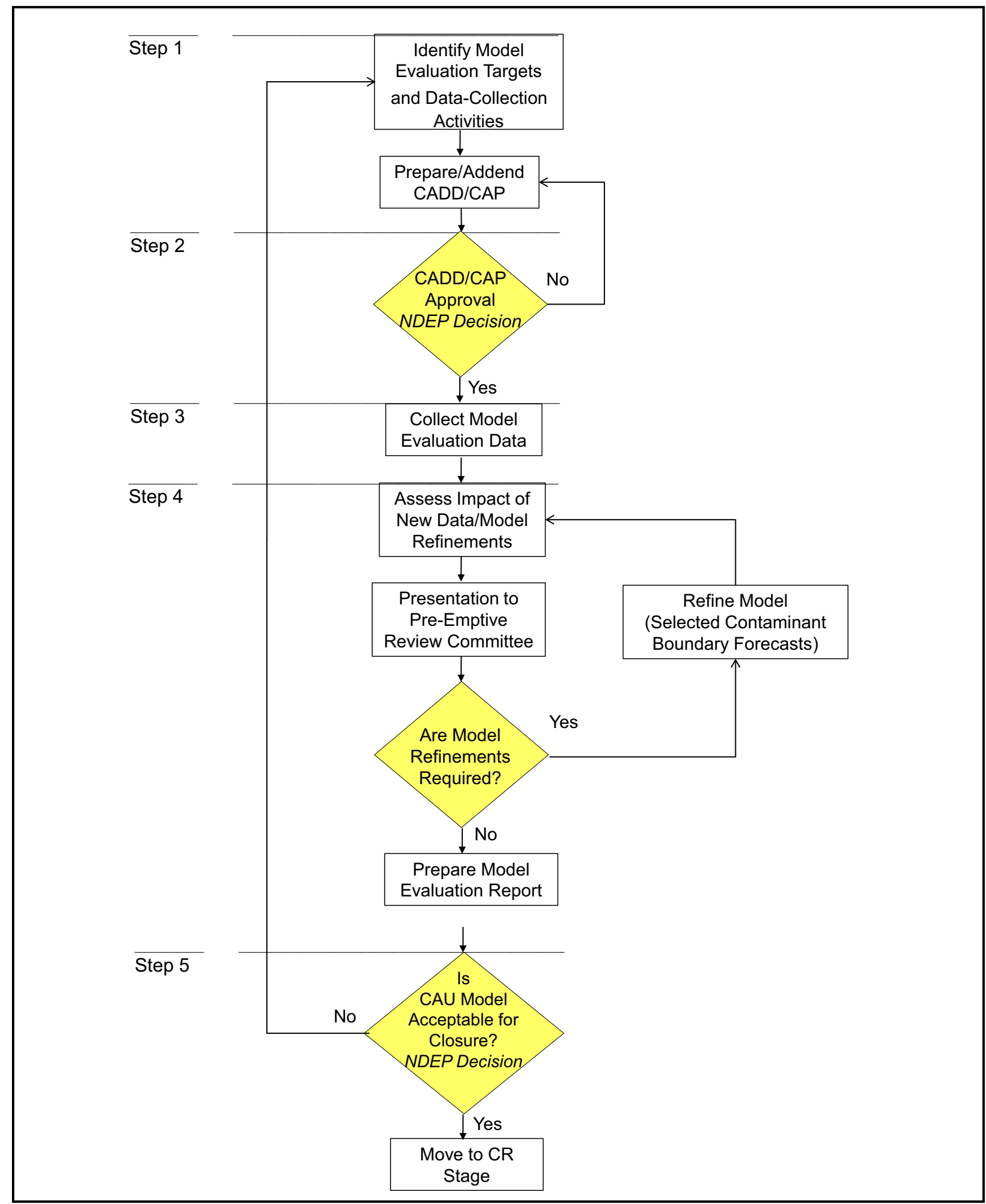

Figure 4-4

Process Flow Diagram for CADD/CAP Model Evaluation Process 
(i.e., the likelihood of success) for reducing the uncertainty associated with each model evaluation target, cost, and ability to meet other objectives (e.g., potential for a new well to fulfill a monitoring role during the CR stage). Cost is evaluated in order to maximize uncertainty reduction while minimizing cost.

Once the data-collection activities are identified, the CADD/CAP or CADD/CAP addendum is prepared. The CADD/CAP or addendum describes the activities proposed, the uncertainties addressed, and the logic behind the selection. A CADD/CAP addendum is prepared with each subsequent iteration of the model evaluation process. The CADD/CAP or addendum is reviewed by the pre-emptive review committee and approved by NNSA/NSO before it is finalized.

\section{Step 2 - NDEP Review of CADD/CAP or CADD/CAP Addendum}

The CADD/CAP or addendum is reviewed by NDEP in Step 2. If the CADD/CAP or addendum is approved, the process will proceed to Step 3. If the CADD/CAP is not approved, it will be revised and resubmitted to NDEP.

\section{Step 3 - Collect Model Evaluation Data}

Data-collection activities are completed in Step 3. The activities are performed in compliance with the UGTA QAPP (NNSA/NSO, 2011) and within the controls established by REOPs, field activity work packages, and/or standard operating procedures.

\section{Step 4 - Assessment of Impact of New Data and Possible Model Refinements}

Step 4 begins with a qualitative and/or quantitative analysis of the new data to assess their impact on the flow and contaminant transport model by the modeling team. The modeling team presents the results of the analysis to the pre-emptive review committee. The presentation will also include the modeling team's preliminary recommendation for model refinements, additional data collection, or advancement to the CR stage. A recommendation for model refinement is based on whether the new data support changes to the conceptual model, such as a different direction of contaminant transport (lateral or vertical), or significantly greater distances of contaminant transport than forecasted. The modeling team will also determine whether the new data indicate that some of the alternative forecasts can be eliminated or given more credence. A recommendation for additional data collection 
will be made if the new data are determined to be insufficient for addressing model uncertainty; model refinement may not be recommended until additional data are collected. A recommendation to proceed to the $\mathrm{CR}$ stage will focus on the adequacy of the model for designing a long-term monitoring network for closure and developing effective institutional controls to restrict public access to groundwater. The recommendations made by the modeling team may be based on scientific judgement rather than quantitative measures.

The pre-emptive review committee then provides the modeling team with recommendations for the path forward. If model refinements are required, the refinements are performed; model refinements may involve re-evaluating some, but not all, of the contaminant boundaries. After model refinement, the process returns to the beginning of Step 4. The modeling team assesses the results of the model refinements and presents their assessment to the pre-emptive review committee.

Once the modeling team, in agreement with the pre-emptive review committee, has determined that further model refinements are not required, the modeling team will prepare a Model Evaluation Report. The Model Evaluation Report will present the following:

- Results of data-collection activities, data and model assessments, and model refinements

- Model uncertainties

- Pre-emptive review committee recommendations to modeling team (from presentations)

- Recommendation to perform additional data collection or proceed to the CR stage

A Model Evaluation Report is prepared for each iteration of the process (Figure 4-4).

\section{Step 5 - Decision To Move to CR or Return to Step 1}

If NNSA/NSO concurs with a recommendation to proceed to the CR stage, the final decision is made by NDEP. The process returns to Step 1 if the model is not considered to be sufficiently reliable for designing a monitoring system or developing effective institutional controls; otherwise, the CAU will proceed to the CR stage. Model uncertainties identified in the Model Evaluation Report are used to select model evaluation targets and data-collection activities to address them (Step 1). 


\subsection{Data-Collection Activities}

Selection of the data-collection activities for the first iteration of the model evaluation process was based on expert evaluation of the Frenchman Flat models to identify model confidence-building targets. The Phase II flow and contaminant transport modeling team-along with additional experts in the Frenchman Flat model specifically; underground nuclear testing in general; and NTS geology, radiochemistry, and hydrology_formed an expert panel to select model-evaluation targets and corresponding data-collection activities (Chapman and Pohlmann, 2011). The expert panel included the modeling team. The uncertainties identified in the Phase II transport model document (NNES, 2010b) were reviewed; 10 model evaluation targets that cover the three primary components of the Frenchman Flat CAU models (HFM, groundwater flow model, and contaminant transport model) were selected and prioritized (Table 4-1).

Having established the model evaluation targets, data-collection programs that could address the targets were identified. The activities recommended by the expert panel for the first iteration of the model evaluation process include conducting surface ground magnetic surveys, and initially installing and collecting data from two model evaluation wells (one well near PIN STRIPE and one near MILK SHAKE) (Chapman and Pohlmann, 2011). Additional data-collection activities (potentially including additional model evaluation wells) will be identified in subsequent iterations of the process and will be described in CADD/CAP addenda. Although not actually recommended by the expert panel, a water-level measurement program will be developed and implemented during the CADD/CAP stage to address the peer-review panel recommendation (Sections 2.4 and 2.5); activities recommended by the peer-review panel that do not include additional data collection (i.e., modeling activities) are described in Section 2.5. The data-collection activities planned for the first iteration of the model evaluation process are described in the following subsections.

\subsubsection{Ground Magnetic Surveys}

Ground magnetic surveys are intended to better define the lateral extent and continuity of the TSA and BLFA at and downgradient of the PIN STRIPE and MILK SHAKE tests, respectively. These units are important because they are the most probable groundwater pathways for contaminant migration away from these tests. The presence or lack of discontinuities in the TSA and BLFA is the principal uncertainty the surveys are designed to reduce. Discontinuities in the lateral extent of the 
Table 4-1

\section{Model Evaluation Targets}

\begin{tabular}{|c|c|c|}
\hline $\begin{array}{c}\text { Model } \\
\text { Evaluation Target }\end{array}$ & Priority & Description of Uncertainty \\
\hline $\begin{array}{l}\text { Source release } \\
\text { conservative } \\
\text { assumptions }\end{array}$ & Top & $\begin{array}{l}\text { The source release model for the vadose zone tests was deliberately } \\
\text { unrealistic, projecting the full source to the water table. More accurate portrayal } \\
\text { of a slower release and possible loss of mass to the vadose zone would reduce } \\
\text { the contaminant mass moving with the groundwater. }\end{array}$ \\
\hline $\begin{array}{l}\text { Internal continuity of } \\
\text { welded-tuff aquifer } \\
\text { (WTA) }\end{array}$ & Top & $\begin{array}{l}\text { The WTA (the TSA specifically) in the vicinity of PIN STRIPE is represented as a } \\
\text { continuous, well-connected HSU in the BASE HFM, which is a bounding } \\
\text { interpretation with respect to contaminant boundaries. However, even modest } \\
\text { vertical displacement on north-south-striking normal faults could completely } \\
\text { disrupt the relatively thin TSA and significantly reduce the continuity of this } \\
\text { potential flow path. }\end{array}$ \\
\hline $\begin{array}{l}\text { Spatial extent of WTA } \\
\text { in the north }\end{array}$ & Middle & $\begin{array}{l}\text { The saturated lateral extent of the WTA (specifically the TSA) at the water table } \\
\text { along the flow path downgradient of PIN STRIPE may be underestimated in the } \\
\text { BASE HFM. If subsurface bed dips in the structural block on the north side of } \\
\text { the detachment fault are steeper than assumed in the BASE HFM, then the } \\
\text { width of saturated TSA would increase along the flow path. }\end{array}$ \\
\hline $\begin{array}{l}\text { Hydraulic conductivity } \\
\text { of WTA }\end{array}$ & Middle & $\begin{array}{l}\text { The parametric distribution of hydraulic conductivity in the WTA could not be } \\
\text { determined with confidence owing to the limited availability of } \\
\text { pumping-test-scale estimates in Frenchman Flat. Although considerably more } \\
\text { data are available for regional HSUs and hydrogeologic unit, the distributions } \\
\text { are not specific to WTAs in Frenchman Flat, and therefore, the data are subject } \\
\text { to issues of transferability. In addition, it is unclear whether high simulated } \\
\text { hydraulic conductivity values in TM-WTA, which have the effect of draining } \\
\text { water from other HSUs, are real or a function of model construction. }\end{array}$ \\
\hline Continuity of BLFA & Middle & $\begin{array}{l}\text { The fractured BLFA lies within the alluvial section at or near the water table near } \\
\text { MILK SHAKE in northern Frenchman Flat. The BASE HFM depicts the BLFA as } \\
\text { three isolated bodies. However, aeromagnetic data, ground magnetic data, and } \\
\text { borehole coverage are insufficient to fully delineate BLFA geometry. }\end{array}$ \\
\hline $\begin{array}{l}\text { Hydraulic conductivity } \\
\text { of BLFA }\end{array}$ & Middle & $\begin{array}{l}\text { There are no pumping-test-scale estimates of hydraulic conductivity in } \\
\text { Frenchman Flat and few relevant NNSS-wide pumping-scale estimates in } \\
\text { the BLFA. }\end{array}$ \\
\hline Size of exchange volume & Middle & $\begin{array}{l}\text { Similar to the above, the exchange volume is assumed to intersect the water } \\
\text { table-when, in fact, it may not-thereby artificially increasing contaminant } \\
\text { access to the saturated zone in the model. }\end{array}$ \\
\hline $\begin{array}{l}\text { Flow } \\
\text { boundary conditions }\end{array}$ & Low & $\begin{array}{l}\text { Groundwater flow boundary conditions, particularly inflow from the north } \\
\text { through semiperched alluvial and volcanic aquifers, are highly uncertain owing } \\
\text { to the absence of field observations in this area and minimal constraints } \\
\text { provided by the regional model. }\end{array}$ \\
\hline $\begin{array}{l}\text { Conceptual model of } \\
\text { basin drainage to } \\
\text { the southeast }\end{array}$ & Low & $\begin{array}{l}\text { As with the boundary flows, large uncertainty exists because there are very } \\
\text { limited data to determine flow directions and velocities with the low gradients. }\end{array}$ \\
\hline $\begin{array}{l}\text { Geochemical age and } \\
\text { velocity constraints }\end{array}$ & Low & $\begin{array}{l}\text { Using }{ }^{14} \mathrm{C} \text { ages, a single groundwater velocity was estimated for each of five } \\
\text { well pairs. Uncertainty arises from the few }{ }^{14} \mathrm{C} \text { ages upon which to estimate } \\
\text { groundwater velocity, uncertainties related to corrections for dead carbon, } \\
\text { and assumptions about how the well pairs are positioned with respect to } \\
\text { flow directions. }\end{array}$ \\
\hline
\end{tabular}


HSUs may impede groundwater flow from the source area to a block of the HSU. Surface ground magnetic surveys will be completed before the recommended wells are installed, because the results of the surveys may have bearing on the locations selected for the wells; investigation of the source term assumptions is best served by a well in hydraulic communication with the source area. The ground magnetic surveys may be supplemented with aeromagnetic data if the modeling team recommends this method for additional data gathering.

\subsubsection{Model Evaluation Wells near PIN STRIPE and MILK SHAKE}

Table 4-2 presents the model evaluation targets for the PIN STRIPE and MILK SHAKE model evaluation wells, and the data-collection activities planned to reduce the uncertainty associated with each target. A drilling advisory team will be assembled to determine the specific geological and geophysical logs to conduct that will best address these model evaluation targets (Table 4-2). The two model evaluation wells were selected to refine the conceptualizations of the geometry of the aquifers and groundwater flow downgradient from the tests. The data-collection programs will focus on acquiring information on the geometry and hydrology of the TSA and BLFA units for the wells near PIN STRIPE (ER-11-2) and MILK SHAKE (ER-5-5), respectively. As previously mentioned, the TSA and BLFA were chosen for evaluating the PIN STRIPE and MILK SHAKE tests, respectively, as the modeling results show that these aquifers are the principal contaminant migration conduits away from the tests. The wells may also provide information regarding the conservative assumptions used for the source release from the underground nuclear tests through the analysis of groundwater samples for the presence of radionuclides. Finally, the wells may provide general information on the conceptual model of basin drainage to the east-southeast, and groundwater age and velocity, both of which can be investigated through water-level measurements and groundwater sampling and analyses. Data collected in these new wells will be interpreted in conjunction with data from existing wells and results of the proposed ground magnetic surveys.

The approximate locations recommended for Wells ER-11-2 and ER-5-5 are shown in Figure 4-5. Figure 4-5 also shows the model-forecasted probabilities of exceeding the SDWA levels (CFR, 2010) at 50 years (i.e., approximately present time). The locations of the wells are expected to provide flow and transport characteristics of the TSA (PIN STRIPE) and BLFA (MILK SHAKE) and guide evaluation of the source release assumptions. The intention is to locate the well beyond the exchange 
Table 4-2

Model Evaluation Target and Potential Data-Collection Activities

\begin{tabular}{|c|c|}
\hline $\begin{array}{l}\text { Model Evaluation Target } \\
\text { (Described in Table 4-1) }\end{array}$ & Data-Collection Activity \\
\hline \multicolumn{2}{|r|}{ ER-5-5 } \\
\hline Hydraulic conductivity of the BLFA & Aquifer testing \\
\hline Continuity of BLFA & $\begin{array}{l}\text { Geologic logging of subsurface rock type, geophysical logging } \\
\text { to determine rock type, dip, and fracture characteristics }\end{array}$ \\
\hline \multicolumn{2}{|r|}{ ER-11-2 } \\
\hline Internal continuity of TSA & $\begin{array}{l}\text { Geologic logging of subsurface rock type, geophysical logging } \\
\text { to determine rock type, dip, and fracture characteristics }\end{array}$ \\
\hline Spatial extent of TSA in the north & $\begin{array}{l}\text { Geologic logging of subsurface rock type, geophysical logging } \\
\text { to determine rock type, dip, and fracture characteristics }\end{array}$ \\
\hline Hydraulic conductivity of the TSA & Aquifer testing \\
\hline Boundary conditions & Measurement of hydraulic head \\
\hline \multicolumn{2}{|c|}{ ER-5-5 and ER-11-2 } \\
\hline Source release conservative assumptions & $\begin{array}{l}\text { Analysis of groundwater samples for } \\
\text { nuclear-test-related contaminants }\end{array}$ \\
\hline Geochemical age and velocity constraints & Analysis of ${ }^{14} \mathrm{C}$ and major ions in groundwater samples \\
\hline $\begin{array}{l}\text { Conceptual model of basin drainage } \\
\text { to the east-southeast }\end{array}$ & Measurement of hydraulic head \\
\hline
\end{tabular}

volume associated with the nuclear test, but close enough to test the model alternatives simulating transport. The screened zone for Well ER-11-2 is designed to encompass the full saturated thickness of the TSA, currently estimated at $20 \mathrm{~m}$ (Figure 4-6); and the screened zone for Well ER-5-5 is designed to encompass the full saturated thickness of the BLFA, currently estimated at $15 \mathrm{~m}$ (Figure 4-7). The wells will be constructed for aquifer testing and sampling operations. The well design will allow the installation of a submersible pump to facilitate groundwater sampling, the use of a water-level probe, and the installation of a pressure transducer. Both wells will be completed using air-rotary drilling methods. In addition to the wells, annular access lines will be installed. The access lines will be of $23 / 8$-inch (in.) carbon-steel casing and stainless-steel slotted screen. The wells will consist of $65 / 8$-in. outer diameter carbon-steel casing and stainless-steel slotted screen. The water levels shown on Figures 4-6 and 4-7 are estimated based on a water-table surface interpolated from actual measurements. 


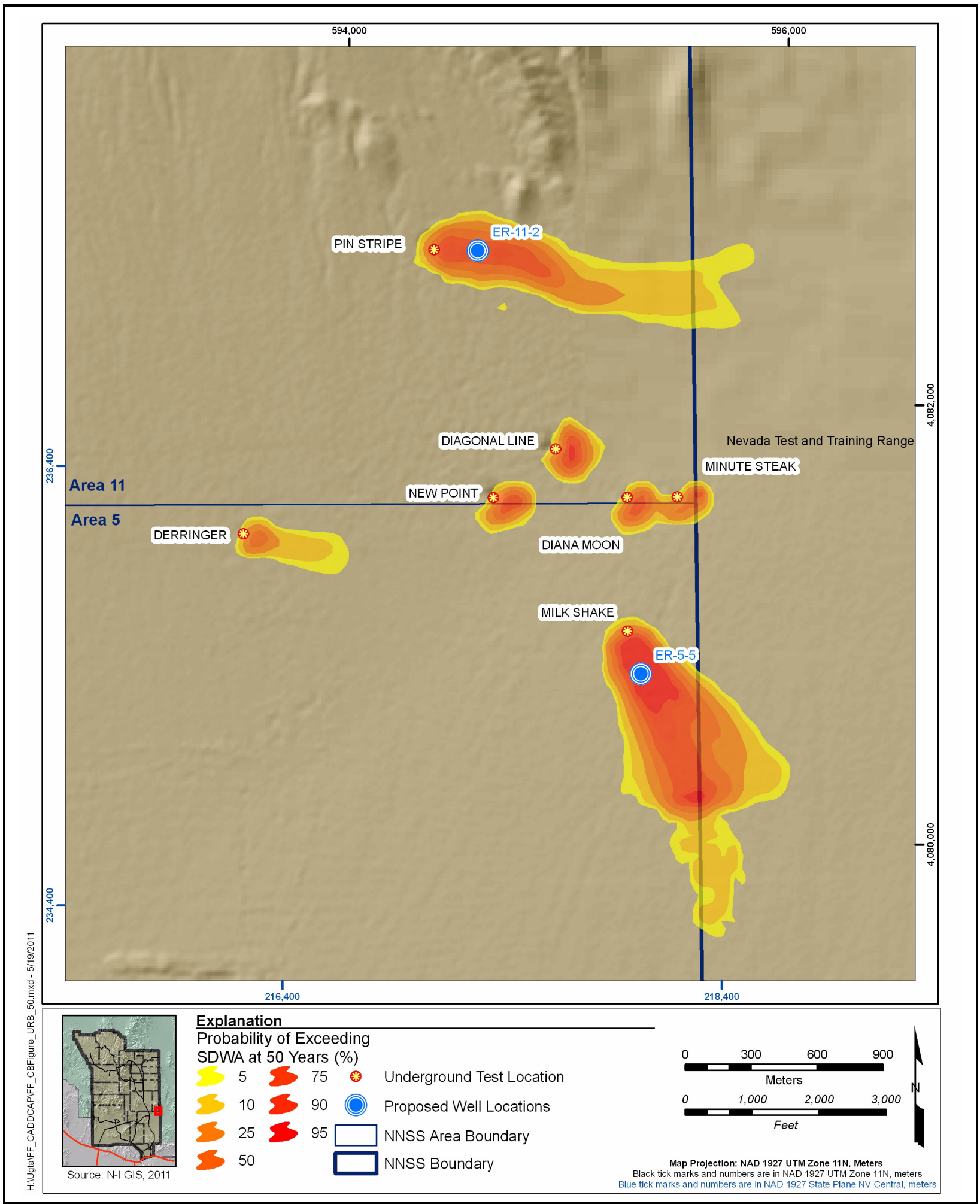

Figure 4-5

Recommended Locations for the Frenchman Flat Model Evaluation Wells 


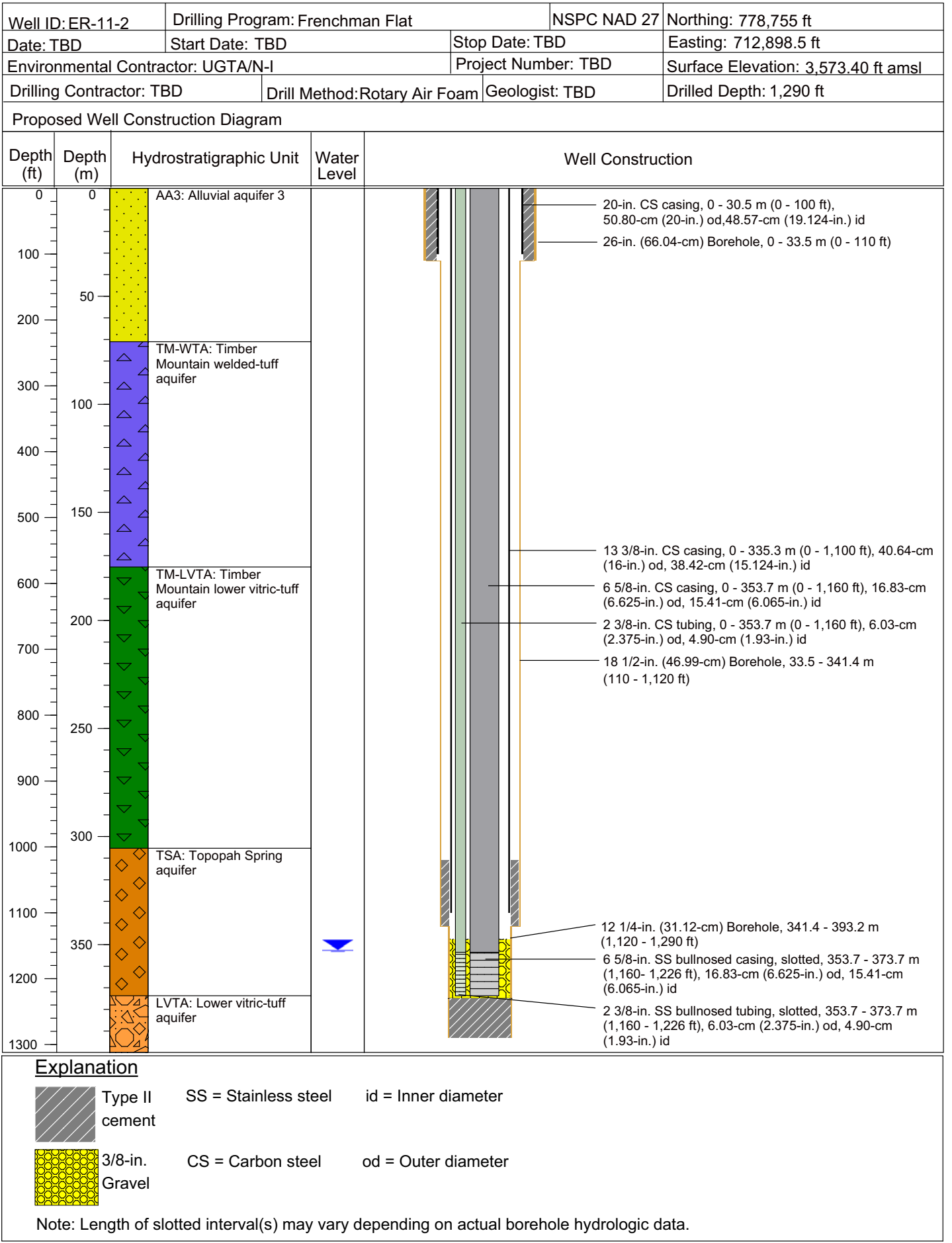

Figure 4-6

Well ER-11-2 Construction Details 


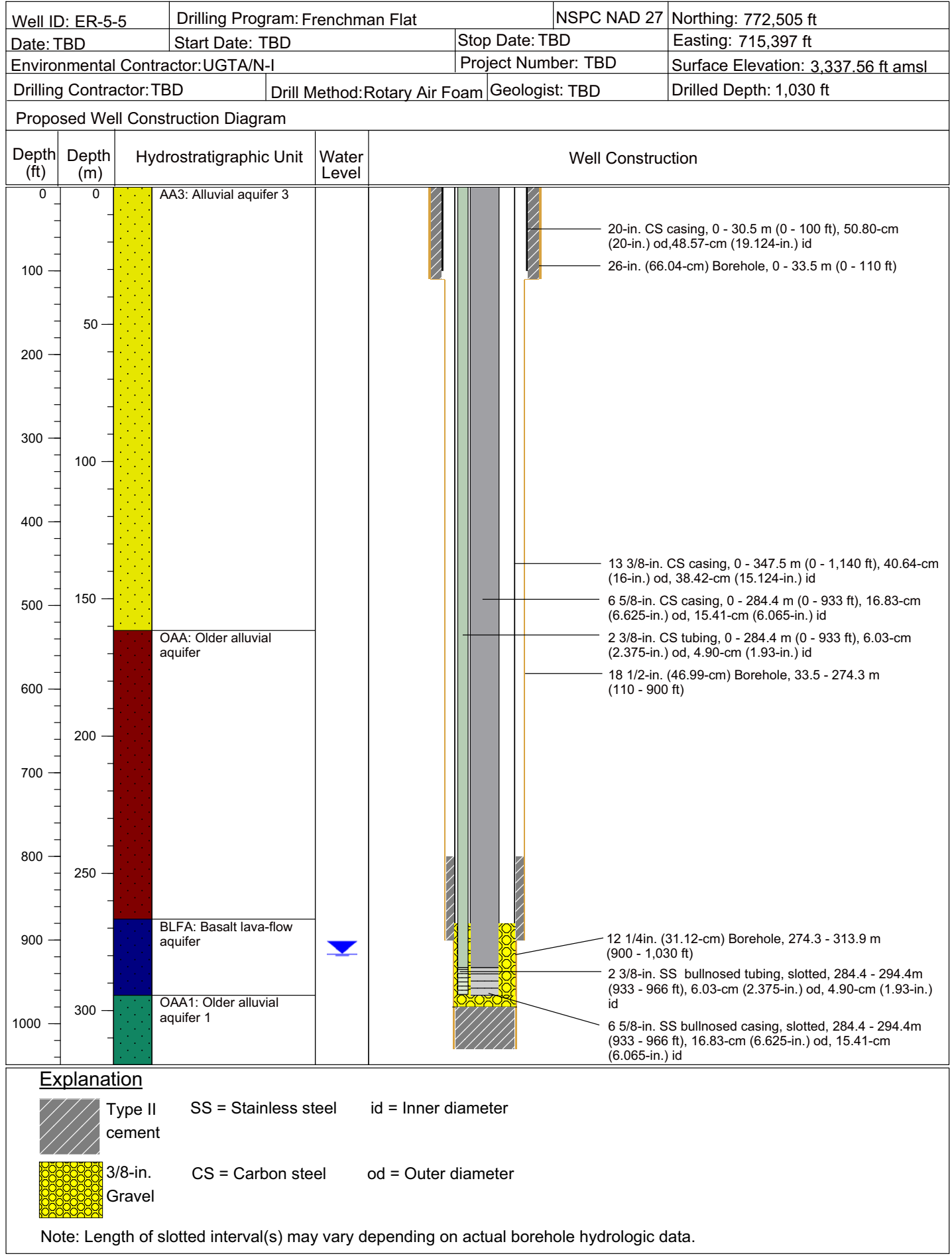

Figure 4-7

Well ER-5-5 Construction Details 
The consistency of newly acquired data and model forecasts, conceptual models, and/or model input data will be evaluated as described in Step 4 of the model evaluation process (Section 4.4). An assessment will include evaluation of each data-collection activity with respect to the associated model evaluation target (Table 4-2). For example, the following evaluations will be used to determine whether new data support, or demonstrate conservatism of, the contaminant boundary forecasts:

- The continuity of the BLFA and TSA HSUs will be evaluated to determine whether the new data support the well-connected units represented in the flow and contaminant transport model.

- Hydraulic conductivities will be evaluated for consistency with the model input data.

- New hydraulic-head data will be evaluated for consistency with a conceptual model of basin drainage to the east-southeast and the boundary conditions of the model.

- Source release conservative assumptions in the model will be evaluated against radionuclide concentrations in the context of measured flow properties

- Groundwater ages and velocities estimated using the new data will be compared with the conceptual model and current model forecasts for all possible well pairs (Figure 1-2) to evaluate the geochemical age and velocity constraints.

\subsubsection{Water-Level Measurement Program}

The water-level measurement program will be implemented during the CADD/CAP stage to monitor water levels in key wells on a regular basis. The objectives of this program are to determine trends in water levels and to possibly determine directions of groundwater flow. This program may support the long-term monitoring program that will be designed and implemented during the CR stage. This work will begin with a high precision resurvey of the wells in Frenchman Flat to precisely determine the coordinates and ground-surface elevation at each well location. In addition, a permanent data point on each of the well casings will be established as a reference for future measurements.

The locations planned for quarterly water-level measurements are listed below (Figure 1-2):

- ER-5-3 shallow piezometer

- ER-5-3 deep piezometer

- ER-5-3 main (upper zone) 
- ER-5-3-2

- ER-5-3-3

- ER-5-4 main

- ER-5-4 piezometer

- ER-5-4-2

- RNM-1

- RNM-2

- UE-5n

- UE-11a

- WW-5A

- WW-5B

One of the wells included for the measurements, UE-11a, has been dry for the last few years and another, RNM-2, has been obstructed in the past. These wells will be checked quarterly for the potential for water-level measurement. In addition, the new model evaluation wells will be included in the quarterly water-level measurement events once well development and testing is completed if determined to be beneficial for model evaluation.

The water levels will be measured over a short interval (days to weeks) during each quarterly measurement event, if possible. Standardized protocol will be established in accordance with the UGTA QAPP (NNSA/NSO, 2011). These water-level measurements will be coordinated with the quarterly monitoring of the pilot wells at the Area 5 RWMC (UE-5 PW-1, UE-5 PW-2, and UE-5 PW-3).

\subsection{Waste Management}

Waste management details may be found in the Underground Test Area Project Waste Management Plan (WMP) (NNSA/NSO, 2009b) and site-specific planning and field documents. The UGTA Project Field Management Plan (FMP) is included as Attachment 1 of the WMP. Waste management covers the segregation, tracking, characterization, and disposal of wastes generated during field activities. The data-collection activities expected to generate waste include drill site construction, well drilling, well completion, well development, testing, and sampling operations. Also, personal protective equipment, sampling equipment, and drilling material waste are generated. The largest volume of waste generated during drilling and sampling activities comprises effluent (fluids) and groundwater. The management of fluids and groundwater produced by well installation activities is addressed in the UGTA Project FMP. Other wastes - such as sanitary, hydrocarbon, and hazardous 
waste - are generated as a result of the operation and maintenance of heavy equipment as well as other support functions as part of the specific type of activity.

Management of investigation-derived waste (IDW) is described in the UGTA Project WMP (NNSA/NSO, 2009b). Details regarding the characterization, storage, treatment, and disposal of wastes generated at investigation sites are addressed in site-specific field instructions or similar working-level documents. Wastes generated are managed and disposed of in compliance with applicable federal, state, and local laws and regulations. The model-evaluation wells will be categorized as a near-field wells, and waste management will include the establishment of a controlled area where radioactive contamination will be closely monitored and managed. The potential for generating hazardous, radioactive, and mixed waste streams are assessed separately for each well location. Field personnel are trained and procedures implemented to address management of radioactive and hazardous waste streams. Waste characterization is based on the results of process knowledge, fluid management monitoring and sampling, and groundwater characterization sampling. This information is used to assign the appropriate waste type (i.e., sanitary, hydrocarbon, hazardous, radioactive, or mixed) to the IDW.

Waste generation is minimized through a comprehensive compliance program. Waste minimization is achieved through the hazardous materials control, materials substitution, and waste segregation. Hazardous materials are controlled, managed, and tracked in accordance with Occupational Safety and Health Administration (OSHA) requirements, and applicable procedures and protocols. Material substitution is implemented wherever possible to prevent or minimize hazardous waste. Waste such as effluent and personal protective equipment is segregated to the greatest extent possible to minimize the generation of hazardous, radioactive, and/or mixed waste.

\subsection{Reporting Requirements}

The first data-collection activity will be the ground magnetic survey, with the results presented in a document prepared after data collection and analysis are completed. Implementation of the water-level measurement program will follow. Installation, completion, and testing of the first two model evaluation wells (ER-5-5 and ER-11-2) will be conducted next. The results of the drilling will be documented in a well completion report, which will present data collected during drilling including, but not limited to, well construction information; borehole logs (e.g., geophysics, flow, 
lithologic, water quality); preliminary water-level measurements; water production; drilling parameters; and the results of radionuclide (i.e., ${ }^{3} \mathrm{H}$ ) monitoring. The well development and testing operations along with the analyses of the resulting data (e.g., aquifer test, water chemistry, and isotopic compositions) are presented in data and analysis reports. In addition, daily drilling, well development and testing, and water-quality measurement activities are reported in morning reports on the UGTA Field Operations website. The results of the activities planned in response to the peer review comments and recommendations (see Appendix A) will be documented and presented to NDEP via interim documents, letters and/or presentations during the CADD/CAP stage. A Model Evaluation Report will be prepared on the results of the evaluation activities. The report will be submitted to NDEP for review. 


\subsection{References}

ASME/RSI, see American Society of Mechanical Engineers and Institute for Regulatory Science.

Appenzeller-Wing, J.L., U.S. Department of Energy, National Nuclear Security Administration Nevada Site Office, Environmental Management. 2009. Letter to R.F. Boehlecke (NNSA/NSO, Environmental Restoration Project) titled "Inclusion of the Area 5 Radioactive Waste Management Complex (RWMC) in the Underground Test Area (UGTA) Compliance Boundary for Corrective Action Unit (CAU) 98 Frenchman Flat," 9 January. Las Vegas, NV.

American Society of Mechanical Engineers and Institute for Regulatory Science. 2001. Technical Peer Review Report, Strategy for Remediation of Groundwater Contamination at the Nevada Test Site, CRTD-Vol. 62. New York, NY.

BN, see Bechtel Nevada.

BN and Neptune, see Bechtel Nevada and Neptune and Company, Inc.

Bechtel Nevada. 2005. A Hydrostratigraphic Framework Model and Alternatives for the Groundwater Flow and Contaminant Transport Model of Corrective Action Unit 98: Frenchman Flat, Clark, Lincoln and Nye Counties, Nevada, DOE/NV/11718--1064. Prepared for the U.S. Department of Energy, National Nuclear Security Administration Nevada Site Office. Las Vegas, NV.

Bechtel Nevada and Neptune and Company, Inc. 2006. Addendum 2 to the Performance Assessment for the Area 5 Radioactive Waste Management Site at the Nevada Test Site, Nye County, Nevada, Update of Performance Assessment Methods and Results. Prepared for the U.S. Department of Energy, National Nuclear Security Administration Nevada Site Office. Las Vegas, NV.

Belcher, W.R., J.B. Blainey, F.A. D’Agnese, C.C. Faunt, M.C. Hill, R.J. Laczniak, G.M. O’Brien, C.J. Potter, H.M. Putnam, C.A. San Juan, and D.S. Sweetkind. 2004. Death Valley Regional Ground-Water Flow System, Nevada and California-Hydrogeologic Framework and Transient Ground-Water Flow Model, Scientific Investigations Report 2004-5205. Reston, VA: U.S. Geological Survey.

Boehlecke, R.F., U.S. Department of Energy, National Nuclear Security Administration Nevada Site Office, Environmental Restoration Project. 2010. Letter to T. Murphy (Nevada Division of Environmental Protection, Bureau of Federal Facilities) titled "Acceptance of the Frenchman Flat Flow and Transport Model for Corrective Action Unit (CAU) 98: Frenchman Flat," 17 November. Las Vegas, NV. 
Bowen, S.M., D.L. Finnegan, J.L. Thompson, C.M. Miller, P.L. Baca, L.F. Olivas, C.G. Geoffrion, D.K. Smith, W. Goishi, B.K. Esser, J.W. Meadows, N. Namboodiri, and J.F. Wild. 2001. Nevada Test Site Radionuclide Inventory, 1951-1992, LA-13859-MS. Los Alamos, NM: Los Alamos National Laboratory.

Bryant, E.A. 1992. The Cambric Migration Experiment, A Summary Report, LA-12335-MS. Los Alamos, NM: Los Alamos National Laboratory.

CFR, see Code of Federal Regulations.

Carle S.F., M. Zavarin, and G.A. Pawloski. 2002. Geostatistical Analysis of Spatial Variability of Mineral Abundance and $K_{d}$ in Frenchman Flat, NTS, Alluvium, UCRL-ID-150200.

Livermore, CA: Lawrence Livermore National Laboratory.

Carle, S.F., R.M. Maxwell, G.A. Pawloski, D.E. Shumaker, A.F.B. Tompson, and M. Zavarin. 2007. Evaluation of the Transient Hydrologic Source Term for the Cambric Underground Nuclear Test at Frenchman Flat, Nevada Test Site, UCRL-TR-226916. Livermore, CA: Lawrence Livermore National Laboratory.

Carr, W.J. 1984. Regional Structural Setting of Yucca Mountain, Southwestern Nevada, and Late Cenozoic Rates of Tectonic Activity in Parts of the Southwestern Great Basin, Nevada and California. U.S. Geological Survey Open-File Report 84-854. Denver, CO: U.S. Geological Survey.

Chapman, J., and K. Pohlmann, Desert Research Institute. 2011. An Expert Elicitation Process in Support of Groundwater Model Evaluation for Frenchman Flat, Nevada National Security Site, DOE/NV/26383-20, Publication No. 45236. Prepared for the U.S. Department of Energy, National Nuclear Security Administration Nevada Site Office. Las Vegas, NV.

Code of Federal Regulations. 2010. Title 40 CFR Part 141, "National Primary Drinking Water Regulations." Washington, DC: U.S. Government Printing Office.

Code of Federal Regulations. 2011. Title 10 CFR Part 835, "Occupational Radiation Protection." Washington, DC: U.S. Government Printing Office.

DoD, see U.S. Department of Defense.

DOE, see U.S. Department of Energy.

DOE/NV, see U.S. Department of Energy, Nevada Operations Office.

Dash, Z.V., B.A. Robinson, and G.A. Zyvoloski. 1996. V\&V Report for the FEHM Application, Report ECD-22. Los Alamos, NM: Los Alamos National Laboratory. 
Doherty, J. 2008. PEST: Model-Independent Parameter Estimation, User's Manual, Version 11. Brisbane, Australia: Watermark Numerical Computing.

EPA, see U.S. Environmental Protection Agency.

FFACO, see Federal Facility Agreement and Consent Order.

Federal Facility Agreement and Consent Order. 1996 (as amended March 2010). Agreed to by the State of Nevada; U.S. Department of Energy, Environmental Management; U.S. Department of Defense; and U.S. Department of Energy, Legacy Management. Appendix VI, which contains the Underground Test Area Strategy, was last modified May 2011, Revision No. 4.

Fenelon, J.M., D.S. Sweetkind, and R.J. Laczniak. 2010. Groundwater Flow Systems at the Nevada Test Site, Nevada: A Synthesis of Potentiometric Contours, Hydrostratigraphy, and Geologic Structures, Professional Paper 1771. Reston, VA: U.S. Geological Survey.

GoldSim, see GoldSim Technology Group, LLC.

GoldSim Technology Group, LLC. 2006. User's Guide: GoldSim Graphical Simulation Environment, Version 9.5. Issaquah, WA.

Halford, K.J., U.S. Geologic Survey. 2002. Memorandum to S. Reiner (USGS) titled "Ground Water-Approval of Aquifer-Test Results; for Test Well WW-4A Welded-Tuff Aquifer, in Area 6, Nevada Test Site, Nye County, Nevada," July 12. Carson City, NV.

Halford, K.J., U.S. Geologic Survey. 2003. Memorandum to S. Reiner (USGS) titled "Ground Water-Approval of Aquifer-Test Results; for Test Well WW-5C Alluvial-Fill Aquifer, in Area 5, Nevada Test Site, Nye County, Nevada," July 16. Carson City, NV.

Hershey, R.L., J.M. Thomas, T.P. Rose, J.B. Paces, I.M. Farnham and F.C. Benedict, Jr. 2005. Evaluation of Groundwater Movement in the Frenchman Flat CAU Using Geochemical and Isotopic Analysis, DOE/NV/13609-36, Publication No. 45207. Prepared for the U.S. Department of Energy, National Nuclear Security Administration Nevada Site Office. Las Vegas, NV: Desert Research Institute.

Hevesi, J.A., A.L. Flint, and L.E. Flint. 2003. Simulation of Net Infiltration and Potential Recharge Using a Distributed-Parameter Watershed Model for the Death Valley Region, Nevada and California, Water-Resources Investigations Report 03-4090. Sacramento, CA:

U.S. Geological Survey.

Hoffman, D.C., R. Stone, and W.W. Dudley, Jr. 1977. Radioactivity in the Underground Environment of the Cambric Nuclear Explosion at the Nevada Test Site, LA-6877-MS. Los Alamos, NM: Los Alamos Scientific Laboratory.

IT, see IT Corporation. 
IT Corporation. 1996. Groundwater Flow Model Documentation Package (Phase I Data Analysis Documentation, Volume VI), ITLV/10972-181. Prepared for the U.S. Department of Energy, Nevada Operations Office. Las Vegas, NV.

IT Corporation. 1997. Value of Information Analysis for Corrective Action Unit No. 98: Frenchman Flat, ITLV/10972--192, UC-700. Las Vegas, NV.

IT Corporation. 1999a. External Peer Review Group Report on Frenchman Flat Data Analysis and Modeling Task, Underground Test Area Project, ITLV/13052--077. Las Vegas, NV.

IT Corporation. 1999b. Written communication. Subject: Underground Test Area Project Corrective Action Unit 98: Frenchman Flat, Volume III-Groundwater Flow and Contaminant Transport Model Documentation Package, Rev. 0. Las Vegas, NV.

IT Corporation. 2000. Lessons Learned from the Frenchman Flat Corrective Action Groundwater Flow and Radionuclide Transport Model, ITLV/13052--121. Las Vegas, NV.

IT Corporation. 2001. Modeling Approach for Corrective Action Unit 98, Frenchman Flat, ITLV/13052--141. Las Vegas, NV.

IT Corporation. 2002. Written communication. Subject: Integrated Data Report for the Multiple-Well Aquifer Test at Frenchman Flat Well Cluster ER-5-3. Las Vegas, NV.

Laczniak, R.J., J.C. Cole, D.A. Sawyer, and D.A. Trudeau. 1996. Summary of Hydrogeologic Controls on Ground-Water Flow at the Nevada Test Site, Nye County, Nevada, Water-Resources Investigations Report 96-4109. Carson City, NV: U.S. Geological Survey.

Maxey, G.B., and T.E. Eakin. 1949. "Groundwater in White River Valley, White Pine, Nye and Lincoln Counties, Nevada." In Water Resources Bulletin No. 8. Carson City, NV: State of Nevada, Office of the State Engineer/U.S. Geological Survey.

Mishra, S. 2002. Assigning Probability Distributions to Input Parameters of Performance Assessment Models, TR-02-11. Prepared by INTERA, Inc. Stockholm, Sweden: Swedish Nuclear Fuel and Waste Management Co.

Moore, C., and J. Doherty. 2005. "Role of the Calibration Process in Reducing Model Predictive Error.” In Water Resources Research, Vol. 41(5): W05020, doi:10.1029/2004WR003501. Washington, DC: American Geophysical Union.

N-I, see Navarro-Intera, LLC.

N-I GIS, see Navarro-Intera Geographic Information Systems.

NNES, see Navarro Nevada Environmental Services, LLC. 
NNSA/NSO, see U.S. Department of Energy, National Nuclear Security Administration Nevada Site Office.

NNSA/NV, see U.S. Department of Energy, National Nuclear Security Administration Nevada Operations Office.

NRC, see National Research Council.

NSTec, see National Security Technologies, LLC.

National Research Council. 2007. Models in Environmental Regulatory Decision Making. Prepared by the Committee on Models in the Regulatory Decision Process. Washington, DC: National Academies Press.

National Security Technologies, LLC. 2008. Closure Plan for the Area 5 Radioactive Waste Management Site at the Nevada Test Site, DOE/NV/25946--553. Prepared for the U.S. Department of Energy, National Nuclear Security Administration Nevada Site Office. Las Vegas, NV.

Navarro-Intera Geographic Information Systems. 2011. ESRI ArcGIS Software.

Navarro-Intera, LLC. 2010. External Peer Review Team Report Underground Testing Area Subproject for Frenchman Flat, Rev. 1, N-I/28091--021. Las Vegas, NV.

Navarro Nevada Environmental Services, LLC. 2010a. Phase II Documentation Overview of Corrective Action Unit 98: Frenchman Flat, Nevada Test Site, Nye County, Nevada, Rev. 1, N-I/28091--007. Las Vegas, NV.

Navarro Nevada Environmental Services, LLC. 2010b. Phase II Transport Model of Corrective Action Unit 98: Frenchman Flat, Nevada Test Site, Nye County, Nevada, Rev. 1, N-I/28091--004, S-N/99205--122. Las Vegas, NV.

Oberlander, P.L. 2001. Letter Report: Hydraulic Conductivity Profile with Depth for Monitor Wells ER-5-3, ER-5-3 \#2, and ER-5-4. Reno, NV: Desert Research Institute.

Oberlander, P.L. 2003. Letter Report: Hydraulic Conductivity Profile with Depth for Well ER-5-4 \#2. Las Vegas, NV: Desert Research Institute.

O’Leary, D.W. 1996. "Tectonic Significance of the Rock Valley Fault Zone, Nevada Test Site." In Seismotectonic Framework and Characterization of Faulting at Yucca Mountain, Nevada, J.W. Whitney ed. Denver, CO: U.S. Geological Survey.

Pavelko, M.T., and K.J. Halford, U.S. Geological Survey. 2004. Memorandum to D. Galloway (USGS) titled "Aquifer Test-Analysis of Multiple-Well Aquifer Test RNM-2s, Frenchman Flat, Nevada," 6 June. Henderson, NV. 
Pawloski, G.A., A.F.B. Tompson, and S.F. Carle eds. 2001. Evaluation of the Hydrologic Source Term from Underground Nuclear Tests on Pahute Mesa at the Nevada Test Site: The CHESHIRE Test, UCRL-ID-147023. Livermore, CA: Lawrence Livermore National Laboratory.

Phelps, G.A., and S.E. Graham. 2002. Preliminary Gravity Inversion Model of Frenchman Flat Basin, Nevada Test Site, Nevada, Open-File Report 2002-363. Denver, CO: U.S. Geological Survey.

Reeves, M., N.A. Baker, and J.O. Duguid. 1994. Review and Selection of Unsaturated Flow Models, Document No. B00000000-01425-2200-00001, Rev. 00. Prepared for the U.S. Department of Energy. Las Vegas, NV: Civilian Radioactive Waste Management System.

Robinson, B.A., and Z.V. Dash. 2006. Written communication. Subject: User 's Guide for the PLUMECALC Application, Version 2.2. Los Alamos, NM: Los Alamos National Laboratory.

Rose, T.P., G.F. Eaton, and A.B. Kersting eds. 2004. Hydrologic Resources Management Program and Underground Test Area Project FY2003 Progress Report, UCRL-ID-206661. Livermore, CA: Lawrence Livermore National Laboratory.

Russell, C.E., and T. Minor. 2002. Reconnaissance Estimates of Recharge Based on an Elevation-dependent Chloride Mass-balance Approach, DOE/NV/11508-37;

Publication No. 45164. Las Vegas, NV: Desert Research Institute, Water Resources Center.

SNJV, see Stoller-Navarro Joint Venture.

Shott, G.J., L.E. Barker, S.E. Rawlison, M.J. Sully, and B.A. Moore. 1998. Performance Assessment for the Area 5 Radioactive Waste Management Site at the Nevada Test Site, Nye County, Nevada, Rev. 2.1, DOE/NV/11718-176. Las Vegas, NV.

Slate, J.L., M.E. Berry, P.D. Rowley, C.J. Fridrich, K.S. Morgan, J.B. Workman, O.D. Young, G.L. Dixon, V.S. Williams, E.H. McKee, D.A. Ponce, T.G. Hildenbrand, W.C. Swadley, S.C. Lundstrom, E.B. Ekren, R.G. Warren, J.C. Cole, R.J. Fleck, M.A. Lanphere, D.A. Sawyer, S.A. Minor, D.J. Grunwald, R.J. Laczniak, C.M. Menges, J.C. Yount, and A.S. Jayko. 1999. Part A. Digital Geologic Map of the Nevada Test Site and Vicinity, Nye, Lincoln, and Clark Counties, Nevada, and Inyo County, California, Revision 4, Open-File Report 99-554-A, scale 1:120,000. Denver, CO: U.S. Geological Survey.

Stoller-Navarro Joint Venture. 2004a. Integrated Analysis Report for Single- and Multiple-Well Aquifer Testing at Frenchman Flat Well Cluster RNM-2s, Nevada Test Site, Nevada, S-N/99205--029. Las Vegas, NV.

Stoller-Navarro Joint Venture. 2004b. Interpretation of Hydraulic Test and Multiple-Well Aquifer Test Data at Frenchman Flat Well Cluster ER-5-3, S-N/99205--028. Las Vegas, NV. 
Stoller-Navarro Joint Venture. 2004c. Phase II Hydrologic Data for the Groundwater Flow and Contamination Transport Model of CAU Unit 98: Frenchman Flat, Nye County, Nevada, S-N/99205-032. Las Vegas, NV.

Stoller-Navarro Joint Venture. 2005a. Letter Report: Analysis of Hydraulic Conductivity and Fracture Porosity in ER-5-3\#2 and ER-5-4\#2 Based on Fracture Data from Borehole Image Logs with Implications for the Tuff Confining Unit Flow Framework, Nevada Test Site, Nevada. August. Las Vegas, NV.

Stoller-Navarro Joint Venture. 2005b. Phase II Contaminant Transport Parameters for the Groundwater Flow and Contaminant Transport Model of Corrective Action Unit 98:

Frenchman Flat, Nye County, Nevada, S-N/99205--043. Prepared for the U.S. Department of Energy. Las Vegas, NV.

Stoller-Navarro Joint Venture. 2005c. Unclassified Source Term and Radionuclide Data for Corrective Action Unit 98: Frenchman Flat Nevada Test Site, Nevada, S-N/99205--058. Las Vegas, NV.

Stoller-Navarro Joint Venture. 2005d. Underground Test Area Fracture Analysis Report for Frenchman Flat Well Clusters ER-5-3 and ER-5-4, Nevada Test Site, Nevada, Rev. 0, S-N/99205--060. Las Vegas, NV.

Stoller-Navarro Joint Venture. 2006. Phase II Groundwater Flow Model of Corrective Action Unit 98: Frenchman Flat, Nevada Test Site, Nye County, Nevada, S-N/99205--074. Las Vegas, NV.

Stoller-Navarro Joint Venture. 2007. Addendum to the Phase II Groundwater Flow Model of Corrective Action Unit 98: Frenchman Flat, Nevada Test Site, Nye County, Nevada, Rev. 0. Las Vegas, NV.

Tompson, A.F.B., C.J. Bruton, and G.A. Pawloski eds. 1999. Evaluation of the Hydrologic Source Term from the Underground Nuclear Tests in Frenchman Flat and the Nevada Test Site: The CAMBRIC Test, UCRL-ID-132300. Livermore, CA: Lawrence Livermore National Laboratory.

Tompson, A.F.B., D.K. Smith, and G.B. Hudson. 2002. Analysis of Radionuclide Migration through a 200-m Vadose Zone following a 16-Year Infiltration Event, UCRL-ID-146979. Livermore, CA: Lawrence Livermore National Laboratory.

Tompson, A.F.B., S.F. Carle, R.M. Maxwell, G. Pawloski, and M. Zavarin. 2005. Evaluation of the Non-Transient Hydrologic Source Term from the CAMBRIC Underground Nuclear Test in Frenchman Flat, Nevada Test Site, UCRL-TR-217191. Livermore, CA: Lawrence Livermore National Laboratory. 
Tonkin, M., and J. Doherty. 2009. "Calibration-Constrained Monte Carlo Analysis of Highly Parameterized Models Using Subspace Techniques." In Water Resources Research, Vol. 45(1): W00B10, doi:10.1029/2007WR006678. Washington, DC: American Geophysical Union.

U.S. Department of Defense. 1999. Renewal of the Nellis Air Force Range Land Withdrawal, Department of the Air Force, Legislature Environmental Impact. Las Vegas, NV.

U.S. Department of Energy. 2003. Use of Institutional Controls, DOE Policy 454.1. Washington, DC.

U.S. Department of Energy. 2005. Institution Controls Implementation Guide for Use with DOE P 454.1, Use of Institutional Controls, DOE Guide 454.1-1. Washington, DC.

U.S. Department of Energy. 2006. Nevada Test Site Environmental Management End State Vision, DOE/NV--958. Prepared by the U.S. Department of Energy, National Nuclear Security Administration Nevada Site Office. Las Vegas, NV.

U.S. Department of Energy, National Nuclear Security Administration Nevada Operations Office. 2001. Addendum to Revision 1 of the Corrective Action Investigation Plan for Corrective Action Unit 98: Frenchman Flat, Nevada Test Site, Nevada, Rev. 1, DOE/NV--478 REV. 1-ADD. Las Vegas, NV.

U.S. Department of Energy, National Nuclear Security Administration Nevada Site Office. 2003. Underground Test Area Quality Assurance Project Plan, Nevada Test Site, Nevada, DOE/NV--341-Rev. 4. Las Vegas, NV.

U.S. Department of Energy, National Nuclear Security Administration Nevada Site Office. 2005a. Completion Report for Well Cluster ER-5-3, DOE/NV/11718--1093. Prepared by Bechtel Nevada. Las Vegas, NV.

U.S. Department of Energy, National Nuclear Security Administration Nevada Site Office. 2005b. Completion Report for Well Cluster ER-5-4, DOE/NV/11718--998. Prepared by Bechtel Nevada. Las Vegas, NV.

U.S. Department of Energy, National Nuclear Security Administration Nevada Site Office. 2006 a. Nevada Test Site Access and Area Control, NSO Order 450.XA. Las Vegas, NV.

U.S. Department of Energy, National Nuclear Security Administration Nevada Site Office. 2006b. Project Screening and Siting Approval Process, NSO Manual 412.X-2. Las Vegas, NV.

U.S. Department of Energy, National Nuclear Security Administration Nevada Site Office. 2009a. Real Estate/Operations Permit, NSO Order 412.X1E. Las Vegas, NV. 
U.S. Department of Energy, National Nuclear Security Administration Nevada Site Office. 2009b. Underground Test Area Project Waste Management Plan, Rev. 3, DOE/NV--343; Attachment 1 Fluid Management Plan for the Underground Test Area Project, Rev. 4; DOE/NV--370. Las Vegas, NV.

U.S. Department of Energy, National Nuclear Security Administration Nevada Site Office. 2010. Las Vegas, NV.

U.S. Department of Energy, National Nuclear Security Administration Nevada Site Office. 2011. Underground Test Area Quality Assurance Project Plan, Nevada Test Site, Nevada, DOE/NV--341-Rev. 5. Las Vegas, NV.

U.S. Department of Energy, Nevada Operations Office. 1996. Final Environmental Impact Statement for the Nevada Test Site and Off-Site Locations in the State of Nevada, DOE/EIS 0243. Las Vegas, NV.

U.S. Department of Energy, Nevada Operations Office. 1997a. Focused Evaluation of Selected Remedial Alternatives for the Underground Test Area, DOE/NV--456. Las Vegas, NV.

U.S. Department of Energy, Nevada Operations Office. 1997b. Regional Groundwater Flow and Tritium Transport Modeling and Risk Assessment of the Underground Test Area, Nevada Test Site, Nevada, DOE/NV--477. Las Vegas, NV.

U.S. Department of Energy, Nevada Operations Office. 1999. Corrective Action Investigation Plan for Corrective Action Unit 98: Frenchman Flat, Nevada Test Site, Nevada, DOE/NV--478, Rev. 1. Las Vegas, NV.

U.S. Department of Energy, Nevada Operations Office. 2000a. Nevada Test Site Resource Management Plan Annual Summary, DOE/NV/604. January. Las Vegas, NV.

U.S. Department of Energy, Nevada Operations Office. 2000b. United States Nuclear Tests, July 1945 through September 1992, DOE/NV--209-REV 15. Las Vegas, NV.

U.S. Environmental Protection Agency. 1994. Remediation Technologies Screening Matrix and Reference Guide, Second Edition, EPA/542/B-94/013; NTIS PB95-104782. Prepared by the DOD Environmental Technology Transfer Committee. Washington, DC.

U.S. Environmental Protection Agency. 2009. Guidance on the Development, Evaluation, and Application of Environmental Models, EPA/100/K-09/003. Washington, DC: Office of the Science Advisor.

Warren, R.G., F.C. Benedict Jr., T.P. Rose, D.K. Smith, S.J. Chipera, E.C. Kluk, and K.M. Raven. 2002. Alluvial Layering and Distribution of Reactive Phases within Drill Holes ER5/4 and UE5N of Frenchman Flat, LA-UR-02-6206. Los Alamos, NM: Los Alamos National Laboratory. 
Winograd, I.J., and W. Thordarson. 1975. Hydrogeologic and Hydrochemical Framework,

South-Central Great Basin, Nevada-California, with Special Reference to the Nevada Test Site, Professional Paper 712-C.

Zyvoloski, G.A., B.A. Robinson, Z.V. Dash, and L.L. Trease. 1997a. Summary of the Models and Methods for the FEHM Application-A Finite-Element Heat- and Mass-Transfer Code, LA-13307-MS. Los Alamos, NM: Los Alamos National Laboratory.

Zyvoloski, G.A., B.A. Robinson, Z.V. Dash, and L.L. Trease. 1997b. User's Manual for the FEHM Application-A Finite-Element Heat- and Mass-Transfer Code, LA-13306-M. Los Alamos, NM: Los Alamos National Laboratory. 


\title{
Appendix A
}

\section{NNSA/NSO Letter Requesting Acceptance of the Frenchman Flat Flow and Transport Model, and Documenting Responses to Phase II Peer Review}

\author{
(11 Pages)
}


November 17, 2010

Tim Murphy, Chief

Bureau of Federal Facilities

Division of Environmental Protection

2030 East Flamingo Road, Suite 230

Las Vegas, NV 89119-0818

\section{ACCEPTANCE OF THE FRENCHMAN FLAT FLOW AND TRANSPORT MODEL FOR CORRECTIVE ACTION UNIT (CAU) 98: FRENCHMAN FLAT}

With the successful completion of the Frenchman Flat Peer Review and recommendations from the Peer Review Panel to move forward into the next stage in the UGTA Strategy, UGTA is requesting your acceptance of the subject model. NDEP's acceptance of this model is the final decision in the Corrective Action Investigation (CAI) stage and is required prior to moving forward into the Corrective Action Decision Document/Corrective Action Plan (CADD/CAP) stage.

Enclosed is the DOE justification for acceptance of the model and path forward to address concerns raised by the Peer Review Panel.

ERP:6982.BW

\section{/s/ Robert F. Boehlecke}

Robert F. Boehlecke

Federal Project Director

Environmental Restoration Project

Enclosure:

As stated 
cc w/encl. via e-mail:

C. D. Andres, NDEP, Las Vegas, NV

J. T. Fraher, DTRA/CXTS, KAFB, NM

S. J. Marutzky, N-I, Las Vegas, NV

T. D. Taylor, N-I, Las Vegas, NV

P. K. Ortego, NSTec, Las Vegas, NV

NSTec Correspondence Control, MS NLV008

NSTec Technical Information Officer, Las Vegas, NV

E. F. Di Sanza, WMP, NNSA/NSO, Las Vegas, NV

W.R. Wilborn, ERP, NNSA/NSO, Las Vegas, NV

FFACO Group, PSG, NNSA/NSO, Las Vegas, NV

NNSA/NSO Read File 


\section{Attachment A}

\section{Justification for Acceptance of Frenchman Flat Flow and Transport Model}

With the successful completion of the Frenchman Flat peer review, Navarro-Intera $(\mathrm{N}-\mathrm{I})$ requests acceptance of the subject model to move forward into the Corrective Action Decision Document/Corrective Action Plan (CADD/CAP) stage. This attachment is to document the justification for model acceptance.

The transmittal to Nevada Division of Environmental Protection (NDEP) of the Final External Peer Review Team Report Underground Testing Area Subproject for Frenchman Flat, Revision 1, September 2010 completes an important step in the Corrective Action Investigation (CAI) stage of the UGTA strategy. The following recommendation is presented in the peer review report (P. 7-2):

"The peer review team concludes that the project team has explored a wide range of variations in assumptions, methods, and data, which builds sufficient confidence in the models to proceed to the CADD/CAP stage."

Given successful completion of the external peer review, $\mathrm{N}-\mathrm{I}$ recommends moving forward to the next step in the CAI stage, which is Decision Step 4 by NDEP as identified in the UGTA strategy chart: is the CAU Model Acceptable for CAOD/CAP?

The purpose of this attachment is to provide justification for acceptance of the Frenchman Flat CAU model by the NDEP. Two topics are covered. First, the key products are identified which complete the required steps of the CAI stage and the justifications for recommending acceptance of the Frenchman Flat Corrective Action Unit (CAU) model are listed. Second, the suggested next steps in NDEP and NSO interactions are summarized for Frenchman Flat including preparations for negotiation of the initial CAU compliance boundary and expected activities for the CADD/CAP studies.

\section{Completion of the Multiple Steps of the Corrective Action Investigation Stage}

The major documents for the Phase II studies of the Frenchman Flat CAU leading to completion of the CAl stage studies up to decision step 4 include:

1. Addendum to Revision 1 of the Corrective Action Investigation Plan for Corrective Action Unit 98: Frenchman Flat, Nevada Test Site, Nevada (NNSA/NV, 2001).

2. Modeling Approach for Corrective Unit 98, Frenchman Flat (IT, 2001) 
3. A Hydrostratigraphic Framework Model and Alternatives for the Groundwater Flow and Contaminant Transport Model of Corrective Action Unit 98: Frenchman Flat, Clark, Lincoln and Nye Counties, Nevada (BN, 2005)

4. Phase II Groundwater Flow Model of Corrective Action Unit 98: Frenchman Flat, Nye County, Nevada (SNJV, 2006)

5. Phase II Transport Model of Corrective Action Unit 98: Frenchman Flat, Nevada Test Site, Nye County, Nevada (NNES, 2010)

6. Phase II Documentation Overview of Corrective Action Unit 98: Frenchman Flat, Nevada Test Site, Nye County, Nevada, Rev 1. (NNES, 2010)

All of these documents were reviewed and accepted by NDEP. The transport document (NNES, 2010) completed and documented the ensemble of contaminant boundaries forecasts required in Section 3 of Appendix VI of the FFACO agreement. The NSO and NDEP agreed that model results from the transport document and data were adequate to proceed to external peer review and this peer review was completed over a six month period during the second half of FY2010.

\section{Recommendation for Model Acceptance}

The justifications for NSO recommending NDEP acceptance of the Frenchman Flat CAU model for CADD/CAP studies are:

1. The recommendation by the External Peer Review Panel that the Frenchman Flat studies progress to the CADD/CAP stage ( $\mathrm{N}-\mathrm{I}, 2010)$.

2. The Phase II studies adequately addressed the recommendations of the Phase I peer review.

3. The transport document (NNES, 2010) addressed the requirements of the FFACO including development of ensembles of contaminant boundary forecasts that incorporate multiple alternatives modeis of boundary conditions, recharge, hydrostratigraphic framework models, alternative sets of calibrated flow models, and Monte Carlo simulations of radionuclide transport in development of ensembles of contaminant boundary forecasts.

4. General consistency in the dimensions and areas of contaminant boundaries for the Frenchman Flat CAU across a range of model assumptions and assessments of statistical and structural uncertainty.

5. Development of sufficient confidence in the transport model results through the integrated and iterative modeling studies of the CAI stage to initiate systematic testing and evaluation of the modeling results through the planned CADD/CAP studies.

6. A reasonable degree of confidence that the remaining issues and uncertainties from transport studies can be adequately evaluated through the planned model evaluation studies under the CADD/CAP stage.

\section{Preparations for the CADD/CAP Stage}


After acceptance of the model at the end of the CAI stage, the NSO would like to start negotiations with NDEP of the initial Frenchman Flat CAU compliance boundary using the technical information and contaminant boundary forecasts in the transport document (NNES 2010).

The NSO concurs with the majority of the recommendations in the external peer review team report and will implement these recommendations in the model evaluation studies. Responses to the issues and recommendations from the external peer review team report (N-I 2010) are included in the attachment to this memorandum. The identified errors in the PlumeCalc code and required changes in the code will be implemented in model refinements as part of the CADD/CAP studies. NSO will complete and submit to NDEP the revisions of the model evaluation subsections of Section 3 of Appendix VI of the FFACO. The recently submitted Model Evaluation Plan $(\mathrm{N}-1,2010)$ is viewed as an evolving project document. It will be revised with incorporation of comments by NDEP in a version to be released in December of 2010. The Model Evaluation Plan will be refined until incorporation as an appendix in the NDEP reviewed CADD/CAP document.

\section{References}

(chronological order)

U.S. Department of Energy, National Nuclear Security Administration Nevada Operations Office, Addendum to Revision 1 of Corrective Action Investigation Plan for Corrective Action Unit 98: Frenchman Flat, Nevada Test Site, Nevada, Rev. 1 DOE/NV-478 Rev.1-ADD (2001).

IT Corporation, Modeling Approach for Corrective Action Unit 98, Frenchman Flat, ITLV/13052-141. Prepared for the U.S. Department of Energy, National Nuclear Security Administration Nevada Operations Office, Las Vegas NV (2001).

Bechtel Nevada, A Hydrostratigraphic Framework Model and Alternatives for the Groundwater Flow and Contaminant Transport Model of Corrective Action Unit 98: Frenchman Flat, Clark, Lincoln and Nye Counties, Nevada, DOE/NV/11718-1067 (2005).

Stoller-Navarro Joint Venture, Phase /I Groundwater Flow Model of Corrective Action Unit 98: Frenchman Flat, Nevada Test Site, Nye County, Nevada, S-N/99205-074 (2006).

Navarro Nevada Environmental Services, LLC, Phase / Transport Model of Corrective Action Unit 98: Frenchman Flat, Nevada Test Site, Nye County, Nevada, Rev. 1, N-1/28091-004,S-N/99205-122, (2010).

Navarro Nevada Environmental Services, LLC, Phase /I Documentation Overview of Corrective Action Unit 98: Frenchman Flat, Nevada Test Site, Nye County, Nevada, N-1/28091-007 (2010).

Navarro-Intera (N-I) Final External Peer Review Team Report Underground Testing Area Subproject for Frenchman Flat, Revision 1, N-I/28091-021-CD, September 2010. 


\section{Attachment B}

\section{External Peer Review Team Report: Comments and Responses by the Underground Test Area Subproject (UGTA) of the Nevada Site Office}

\section{Introduction}

The external peer review team for the Frenchman Flat corrective action unit (CAU) was tasked with answering three questions:

1. Are the modeling approaches, assumptions and model results for Frenchman Flat consistent with the use of modeling studies as a decision tool for resolution of environmental and regulatory requirements?

2. Do the modeling results adequately account for uncertainty in models of flow and transport in the Frenchman Flat hydrological setting?

a. Are the models of sufficient scale/resolution to adequately predict contaminant transport in the Frenchman Flat setting?

b. Have all key processes been included in the model?

c. Are the methods used to forecast contaminant boundaries from the transport modeling studies reasonable and appropriate?

d. Are the assessments of uncertainty technically sound and consistent with state-of-theare approaches currently used in the hydrological sciences?

3. Are the data sets and modeling results adequate for a transition to Corrective Action Unit monitoring studies - - the next stage in the Underground Test Area strategy for Frenchman Flat?

The review team responded affirmatively in their final report (External Peer Review Team Report Underground Testing Area Subproject for Frenchman Flat, N-1/28091-021, September, 2010) to all three questions and complimented the UGTA for their thorough evaluation of processes that could affect radionuclide migration, for assessments of uncertainty and model evaluations that ". . go far beyond those conducted at other contaminated sites in the United States" and for their expertise in the surface and subsurface geology and structure of the Frenchman Flat basin. The overall results of the external peer review are positive and favorable and the panel concluded that the UGTA studies for the Frenchman Flat corrective action unit (CAU) ". . should proceed to the next stage with an emphasis on monitoring studies."

The peer review team provided a wealth of comments, observations and recommendations all designed to aid future monitoring studies. They also identified issues that should be addressed in the next stage(s) of the CAU activities. The purpose of this discussion is twofold:

1. Document the responses by the UGTA subproject to the issues and recommendations of the external peer review. 
2. Identify issues that will be evaluated in the Corrective Action Decision Document/Corrective Action Plan stage (CADD/CAP) and/or the Closure Report stage (CR) of the continuing studies for the Frenchman Flat CAU.

\section{Issues and Responses}

These responses cover the issues summarized by the peer review team report as a bullet list in the executive summary (Pages ES-2 to ES-3). Responses are provided in italic font for each of the bullet items.

Issue One: Evaluation and use of water-level gradients from the Pilot Wells at the Area $\mathbf{5}$ Radioactive Waste Management Complex in model calibration. See Section 3.1 Water-Level Data, pages 3-1 to 3-9 and Figures 3-1 to 3-4 in the report of the external peer review panel $(\mathrm{N}-\mathrm{I}, 2010)$.

The peer review team was provided more current monitoring data for the pilot wells than the data available for calibration of the original Frenchman Flat flow model (SNJV, 2006.). The groundwater flow directions using the new pilot well monitoring data are overlap with estimated flow directions from the Frenchman Flat modeling studies (flow varying from east, to southeast to south). The new monitoring results may be permissive with south-southwest groundwater flow from the northern testing area. NSO agrees with the opinion of the peer review team that the pilot well data should continue to be evaluated in CADD/CAP and CR studies. The pilot well data will be updated and evaluated with continuing monitoring results during the CADD/CAP studies (see also the response to (ssue nine below).

Issue Two: Re-evaluation of the use of geochemical age-dating data to constrain model calibrations. See Sections 3.2.1 Groundwater Age, pages 3-10 to 3-12, Figure 3-7 and Section 3.2.3 Use of Groundwater Age in NHA Model, pages 3-14 to 3-17 and Figure 3-10 (N-I, 2010).

There is agreement with the peer review observation that methods used to estimate groundwater ages are uncertain and there are concerns with aspects of the data (for example, screened intervals for wells used to collect groundwater samples, spatial patterns of groundwater ages). Moreover, the application of groundwater age information can be ambiguous for some model interpretations/calibrations. However, spatial patterns of groundwater ages are more systematic when screened by aquifer type and interpretations of groundwater ages can be very informative when interpreted in the context of other data constraints and conceptual models of groundwater flow in the Frenchman Flat basin. Given the sparse datasets for the basin, NSO maintains that all information should be considered in model calibrations and in interpretations of model results. Further, age constraints were used only in calibration of one alternative model (NHA model) for the ensemble of contaminant boundary forecasts. Groundwater age information will be interpreted recognizing data uncertainties, but this information will continue to be assessed in CADD/CAP and $C R$ studies.

Issue Three: Development of water budgets for the alluvial and upper volcanic aquifer systems in Frenchman Flat. See Section 3.5 Groundwater Budget Synthesis, pages 3-23 to 3-25 and Figure 3-11 (N-I, 2010). 
Water budgets for the Frenchman Flat groundwater system are discussed in Section 3.5 of the peer review report. NSO agrees with the conceptual model of the Frenchman Flat basin illustrated in Figure 311 of the peer review report, where this figure represents a systems approach to the basin water balance. This figure is fully consistent with conceptual model used in the Frenchman Flat flow and transport modeling studies. NSO also agrees that water fluxes at model boundaries are uncertain and much of this uncertainty may be irreducible. Uncertainties in water budgets were evaluated in the modeling studies through a combination of alternative models of boundary conditions and recharge assumptions (structural uncertainty) and automated calibrations and exploration of parameter null space using PEST optimizations (statistical uncertainty). The peer review opinion that the magnitudes of most inflow terms in the modeling studies were overestimated is a valid observation and this resulted in overestimation of lateral transport of radionuclides. The modeling approach for Frenchman Flat used multiple bounding assumptions in initial model development (Corrective Action investigation stage; CAl). Continuing studies for the CADD/CAP and CR stages will attempt to use parameters and assumptions that are more representation of the expected case including assumptions for inflow terms.

Issue Four: Consideration of modeling approaches in which calculated groundwater flow directions near the water table are not predetermined by model boundary conditions and areas of recharge, all of which are very uncertain. See Section 3.5 Groundwater Budget Synthesis, pages 3-23 to 3-25 and particularly the discussion at the end of page 3-25 (N-I, 2010).

This issue follows from the discussion of Issue three and the conceptual model shown on Figure 3-11 of the peer review report. All groundwater modeling studies are inherently dependent on uncertain estimations of boundary fluxes at model edges and recharge assumptions. For Frenchman Flat, the inflows and resulting groundwater flow directions are largely determined by recharge in areas of higher topography and the hydrogeologic features of the basin. Uncertainty from these boundary conditions is incorporated in the ensemble of contaminant boundary forecasts. The core of the problem is the level of confidence in model estimations of flow directions, a question that will be emphasized in the model evaluation of the CADD/CAP stage. The first two scheduled model evaluation wells are at sites chosen to explore model results which are strongly dependent on local directions of groundwater flow and radionuclide transport. This approach is consistent with the recommendations of the peer review panel (page 9-2).

Issue Five: Evaluation of local-scale variations in hydraulic conductivity on the calculated contaminant boundaries. See Section 3.3 Permeability Data, pages 3-17 to 3-19 (N-I, 2010).

Section 3.3 of the peer review report provides a range of useful comments on the assignment of permeability data in the modeling studies. NSO agrees that a single-value representation of the hydraulic conductivity for hydrostratigraphic units could omit preferential flow and/or fast pathways and locally underestimate groundwater flow in alluvial layers. However, the impact of these issues on contaminant boundaries for underground tests in alluvium may be minimal because of the low gradients and current low velocities in Frenchman flat. The potential for local-scale variations in permeability will be considered in evaluations of new data collected during the CADD/CAP stage. 
Issue Six: Evaluation of the effects of non-steady state flow conditions on calculated contaminant boundaries including the effects of long-term declines in water levels, climatic change and disruption of the groundwater system by potential earthquake faulting along either of the two major controlling fault zones in the flow system, the Cane Springs and Rock Valley faults. See Section 8.0 Static Analysis, pages 8-1 to 8-7 and sub-Section 8.1 Climate Change, pages 8-1 to 8-2, 8.2 Earthquake Faulting, pages 82 to 8-7 and Figures 8-1 and 8-2 (N-1, 2010).

NSO agrees that the potential effects of non-steady state flow should be considered and will implement a water-level monitoring program during model evaluations for the CADD/CAP with continuation into the CR stage.

Based on regulatory precedence established through other programs (Waste Management, Yucca Mountain, the Waste Isolation Pilot Plan, and associated regulatory requirements of DOE Order 435.1, and EPA 40 CFR 191), formal assessments of potentially disruptive events (features, events and processes or $F E P S$ ) are typically not required for 1,000 year compliance intervals but are required for 10,000 year compliance intervals. The 1,000 year assessments for most Environmental Management programs across the DOE complex are based on current conditions and current processes. Section 3 of Appendix VI of the FFACO states that models of flow and transport will generally be based on steady state assumptions - non-steady state conditions and assessment of seismic events will be considered in consultation with NDEP after acceptance of the individual CAU models for the CADD/CAP and CR stages.

With respect to climate change, the UGTA subproject will continue to follow the scientific literature on anthropogenic driving forces for climate change particularly for the topic of abrupt climate change which could affect climate assumptions during the next 1,000 years. A current limitation in climate change models is the transition required from global climate models to regional models, an area of active topical research. The UGTA subproject, in consultation with NDEP, will periodically assess progress in development of regional scale models for the arid southwest United States and reassess the need for further studies during the CADD/CAP and CR stages.

With respect to future effects of faulting, the Frenchman Flat basis is seismically active and the hydrologic and geologic system of the basin has adapted over geologic time to the tectonic setting and seismicity of the basin. For earthquake activity to be an issue, there would have to be a future seismic event that disrupts the geologic setting and that disruption would have to significantly perturb the hydrologic system (a low-likelihood conditional probability). Sensitivity analysis of the effects of discrete sets of plausible seismic events will be considered in consultation with NDEP during future studies (CADD/CAP or CR stages).

Issue Seven: Consideration of the use of less-complex modeling approaches. See Sections 9.3 Recommendations on Model Development, page 9-2 to 9-3 and 9.4 Recommendations on Model Complexity, pages 9-3 to 9-5 (N-I, 2010).

See the discussion in the following section on model complexity and sophistication of groundwater studies.

Issue Eight: Evaluation the large change in water levels in the vicinity of the Frenchman Flat playa and development of a conceptual model to explain these water-level changes. See Section 3.1 Water-Level Data pages 3-1 to 3-9, discussion in the middle of page 3-5 and Figures 3-5 and 3-6 (N-I, 2010). UNCONTROLLED When Printed 
This issue will be evaluated in two stages. First, the existing data will be assessed during the CADD/CAP stage to ensure the water level measurements and resulting water-level differences are not in error. This will be combined with continued long-term monitoring of water levels for all wells (see response to Issue nine). Second, if the large changes in water levels are verified as part of CADD/CAP water-level monitoring studies, the potential effects of local structure will be evaluated and local models of geologic structure revised, if required.

Issue Nine: Development of a long-term groundwater level monitoring program for Frenchman Flat with regular monitoring of water levels at key monitoring wells. See Sections 3.1 Water-Level Data pages 3-1 to 3-9 and 9.2 recommendations on Water-Level Monitoring, page 9-2 (N-I, 2010).

A groundwater level monitoring program for Frenchman Flat is planned to begin with the installation of the first two model evaluation wells. This program will include:

1. Re-surveying of well head elevations,

2. Developing a standardized protocol for measurement of water levels,

3. Resurveying of water levels in all wells in Frenchman Flat during a short interval (days to weeks) to minimize possible effects of barometric pressure, water temperature, and earth tides on water levels, and

4. Routine monitoring of water levels on an established schedule.

The details and schedule for this monitoring program will be described in the CADD/CAP document.

\section{Discussion of Model Complexity and Sophistication in Groundwater Studies}

The peer review provided comments and recommendations in the executive summary, and recommendations (Section 9.0) on the issue of model complexity, sparse data and sophistication of the modeling studies $(\mathrm{N}-\mathrm{I}, 2010)$. They note a disparity between the quantity of constraining data and the complexity of model calculations and suggested that the detailed modeling analysis could provide a false sense of confidence in model results. They argue ( $p .9-5$ of N-I, 2010) that there may not be a proper balance between the detail of data and model and suggest similar conclusions for the CAl stage of the CAU studies could have been obtained with simpler models.

The question of model approaches and the balance between data and model complexity is a currently debated topic in the hydrological literature. There are two competing schools of thought. The first argues that data should constrain all model development and models should be no more complex than supporting data. The second school argues that model development and application is an information tool for decision making and models can be extended beyond immediate data constraints to provide information as an aid to decision makers.

The UGTA subproject does not want to weigh in on the modeling debate and does not expect the debate to be resolved within the near term. Instead, the emphasis of the UGTA program is on effective use of modeling studies to meet regulatory goals. These goals are described in the FFACO.

The NSO recognizes the concerns of the peer review team and three perspectives are provided.

1. There was no intent in the modeling studies of Frenchman flat for model complexity to obscure or provide a false sense of confidence in the modeling results - the Frenchman Flat 
modeling documents describe how data do not inform many components of the model (see Section 7.0 Model Evaluation of the transport document, NNES 2010). The primary goal of the UGTA CAl studies is to provide multiple sets of forecasts of contaminant boundaries. The calculations for the contaminant boundaries are complicated and all model results are displayed instead of model-averaged results.

2. Second, the complexity of the modeling reflects the sparse data sets, the complexity of the hydrogeologic setting and limitations in the ability of modeling to definitively identify contaminant boundaries. Multiple sets of alternative model approaches are used to explore the full range of permissive alternatives required by the limited data and non-unique modeling assumptions.

3. NSO is exploring alternative ways to better structure complex modeling approaches and model results using combined approaches of bottom-up process modeling and top down system modeling. The NSO will provide information to NDEP on changes in modeling approaches in future briefings, and these changes will be described in CAU-specific model documents submitted for NDEP review. The first descriptions of the refined modeling approaches will be in the CADD/CAP document for Frenchman Flat and in the Phase II modeling for the western and center Pahute Mesa. These descriptions will be developed in consultation and agreement with the NDEP. The goals are to streamline modeling approaches and achieve increased transparency in communication of modeling results.

\section{References}

Navarro Nevada Environmental Services, LLC, Phase /I Transport Model of Corrective Action Unit 98: Frenchman Flat, Nevada Test Site, Nye County, Nevada, Rev. 1, N-1/28091-004,S-N/99205-122, (2010).

Navarro-Intera (N-I) Final External Peer Review Team Report Underground Testing Area Subproject for Frenchman Flat, Revision 1, N-I/28091-021-CD, September 2010.

N-I, Model Evaluation Plan for Corrective Action Unit 98: Frenchman Flat, Nevada National Security Site, Nevada, N-I/28091 - XXX-CD, Revision 0, September 2010. 


\title{
Appendix B
}

\section{NDEP Letter Accepting the Frenchman Flat Flow and Transport Model}

\author{
(2 Pages)
}




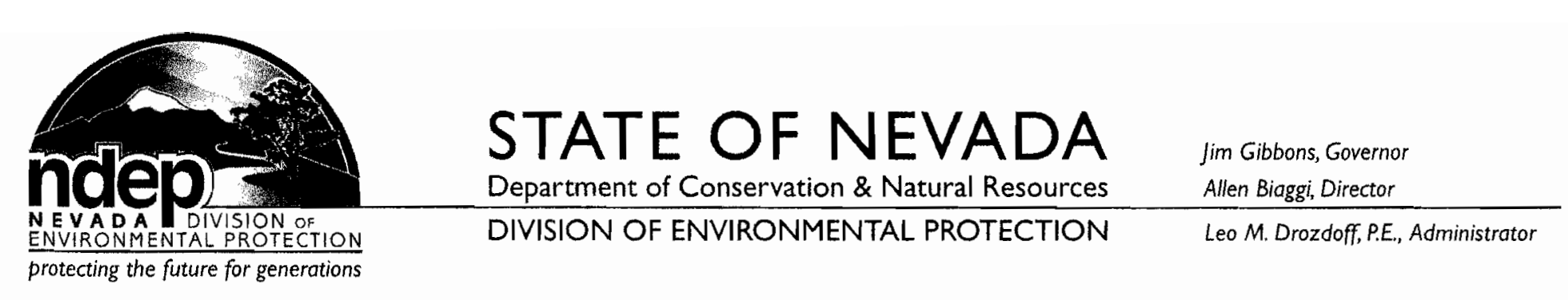

November 30, 2010

Mr. Robert F. Boehlecke

Federal Project Director

Environmental Restoration Division

National Nuclear Security Administration

Nevada Site Office

P.O. Box 98518

Las Vegas, Nevada $89193-8518$

RE: Acceptance of the Frenchman Flat Flow and Transport Model for Corrective Action Unit (CAU) 98: Frenchman Flat

Federal Facility Agreement and Consent Order

Dear Mr. Boehlecke:

The Nevada Division of Environmental Protection, Bureau of Federal Facilities staff (NDEP) has received and reviewed the above-referenced request and attached documentation from the National Nuclear Security Administration / Nevada Site Office (NNSA / NSO). While the NDEP does not agree with all of the Peer Review's comments and recommendations to the NNSA / NSO about the Frenchman Flat model, the NDEP does find that all of our Agency's comments and recommendations in regards to the model are adequately addressed by the NNSA / NSO's responses to the Peer Review comments and recommendations.

Therefore, pursuant to Section 3.0 of Appendix VI of the FFACO, the NDEP accepts the Frenchman Flat model with the conditions that: (1) all actions previously agreed to between the NNSA / NSO and the NDEP in regards to the revisions to Section 3.0 of Appendix VI of the FFACO, the Model Evaluation Plan and corrections to the code errors; (2) all planned actions in Attachment B of the above-referenced document be identified in the Frenchman Flat Corrective Action Decision Document / Corrective Action Plan. The results of all of these actions must be documented and presented to the NDEP via interim documents, letters or presentations during the CADD / CAP stage.

If you have any comments, questions or need clarification regarding anything written above, please contact Christine Andres at 702-486-2850, ext. 232. 
Mr. Robert F. Boehlecke

Page 2 of 2

November 30,2010

Sincerely,

\section{/s/ Tim Murphy}

T. M. Mutphy

Chief

Bureau of Federal Facilities

CDA/MM/EAJ: $c d a$

cc: E. F. DiSanza, WMP, NNSA/NSO, Las Vegas, NV

FFACO Group, PSG, NNSA/NSO, Las Vegas, NV

W. R. Wilborn, ERP, NNSA/NSO, Las Vegas, NV

J. T. Fraher, DTRA/CXTS, Kirtland AFB, NM

T. D. Taylor, N-I, Las Vegas, NV

S. J. Marutzky, N-I, Las Vegas, NV

P. K. Ortego, NSTec, Las Vegas, NV

NSTec Technical Information Officer, Las Vegas, NV 


\title{
Appendix C
}

\section{Nevada Division of Environmental Protection Comments}

- Rev. 0 Document Review Sheet

- $\mathrm{N}-\mathrm{I}$ response to Fenelon comments (30 June 2011)

- NDEP email request and N-I reply (5 July 2011)

\author{
(7 Pages)
}


NEVADA ENVIRONMENTAL RESTORATION PROJECT UGTA DOCUMENT REVIEW SHEET

\begin{tabular}{|c|c|c|c|c|}
\hline \multicolumn{4}{|c|}{ 1. Document Title/Number: Draft CADD/CAP for CAU 98: Frenchman Flat } & 2. Document Date: May 2011 \\
\hline \multicolumn{4}{|c|}{ 3. Revision Number: 0 (Final) } & 4. Originator/Organization: Irene Farnham/NI \\
\hline \multicolumn{4}{|c|}{ 5. Responsible DOE NNSA/NSO Subproject Mgr.: Bill Wilborn } & 6. Date Comments Due: July 7, 2011 \\
\hline \multicolumn{4}{|c|}{ 7. DRS Return Location: NA } & 8. Review Criteria: Complete Document \\
\hline \multicolumn{5}{|c|}{ 9. Reviewer Name/Organization/Phone No.: Nevada Division of Environmental Protection (NDEP) } \\
\hline $\begin{array}{l}\text { 10. Comment } \\
\text { No. (Priority) } \\
\end{array}$ & \begin{tabular}{|l|} 
11. Location \\
(Pg, Sect, Line)
\end{tabular} & 12. Type ${ }^{a}$ & 13. Comment & 14. Comment Response \\
\hline 1. & $\begin{array}{l}\text { Page ES-I, } \\
\text { 2nd paragraph, } \\
\text { 1st sentence } \\
\text { and } \\
\text { Page 5, } \\
\text { Section 1.2, } \\
\text { 1st paragraph, } \\
\text { 1st and 2nd } \\
\text { sentence }\end{array}$ & $\mathrm{T}$ & $\begin{array}{l}\text { The NDEP is not cognizant where the purpose of the } \\
\text { UGTA Sub-Project stated in these sentences is } \\
\text { documented. Also, the NDEP has never agreed that the } \\
\text { UGT A Sub-Project would be a risk-assessment project. } \\
\text { Section } 3.2 \text { of the FFACO states that the primary objective } \\
\text { of the UGTA strategy is to define perimeter boundaries for } \\
\text { each CAU over the next } 1,000 \text { years. The statements in the } \\
\text { CADD/CAP should be consistent with what is stated in the } \\
\text { signed FFACO or a reference should be provided for the } \\
\text { given statement(s). }\end{array}$ & $\begin{array}{l}\text { The sentence in the executive summary was removed. } \\
\text { On page } 5 \text {, the sentence was changed to: The primary } \\
\text { purpose of the UGTA Sub-Project is to define perimeter } \\
\text { boundaries for each CAU over the next } 1,000 \text { years that } \\
\text { enclose areas potentially exceeding the radiological } \\
\text { standards of the Safe Drinking Water Act } \\
\text { (SDWA) (CFR, 2010). }\end{array}$ \\
\hline 2. & $\begin{array}{l}\text { Pg. ES-I, } \\
\text { 3rd paragraph, } \\
\text { 3rd sentence } \\
\text { and } \\
\text { Pg. } 32, \\
\text { Sections. } 3.0 \text { and } \\
\text { 3.1 }\end{array}$ & $\mathrm{T}$ & $\begin{array}{l}\text { The NDEP is not cognizant where the corrective action } \\
\text { objectives and the actions recommended to meet the } \\
\text { objectives referenced on Page ES-1 and in Section } 3.0 \text { and } \\
\text { detailed in Section } 3.1 \text { are documented. (These objectives } \\
\text { are also referenced on Page } 34 \text {, Second Paragraph, Third } \\
\text { Sentence.) Again, Section } 3.2 \text { of the FFACO states that the } \\
\text { primary objective of the UGTA strategy is to define } \\
\text { perimeter boundaries for each CAU over the next } 1,000 \\
\text { years. The statements in the CADD/CAP should be } \\
\text { consistent with what is stated in the signed FFACO or a } \\
\text { reference should be provided for the given statement(s) in } \\
\text { the CADD/CAP. }\end{array}$ & $\begin{array}{l}\text { The text on page } 32 \text { was revised to read: The objective } \\
\text { of the corrective actions for the Frenchman Flat CAU is } \\
\text { to identify the nature and extent of the contamination to } \\
\text { ensure the public and the environment are protected } \\
\text { from exposure to the contamination. }\end{array}$ \\
\hline 3. & $\begin{array}{l}\text { Page } 9 \\
\text { Section 2.0, } \\
\text { 2nd paragraph, } \\
\text { 2nd sentence }\end{array}$ & $\mathrm{T}$ & $\begin{array}{l}\text { It is not clear why the actions of the Phase I CAI listed in } \\
\text { the first sentence are referred to as a "strategy" in the } \\
\text { second sentence and why this "strategy" was "predicted." It } \\
\text { may be better to begin the sentence with "The assumption } \\
\text { was made that no new site ... " to reflect the actual thought }\end{array}$ & The sentence was changed as suggested. \\
\hline
\end{tabular}

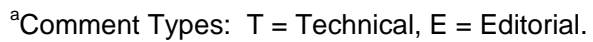

\section{UNCONTROLLED When Printed}


NEVADA ENVIRONMENTAL RESTORATION PROJECT UGTA DOCUMENT REVIEW SHEET

\begin{tabular}{|c|c|c|c|c|}
\hline $\begin{array}{l}\text { 10. Comment } \\
\text { No. (Priority) }\end{array}$ & $\begin{array}{l}\text { 11. Location } \\
\text { (Pg, Sect, Line) }\end{array}$ & 12. Type ${ }^{a}$ & 13. Comment & 14. Comment Response \\
\hline & & & process at that time. & \\
\hline 4. & $\begin{array}{l}\text { Page } 32, \\
\text { Section } 3.2, \\
\text { 1st paragraph, } \\
\text { 1st sentence }\end{array}$ & $\mathrm{E}$ & $\begin{array}{l}\text { The phrase "described in Appendix VI of the FFACO } \\
\text { (1996, as amended)" should be removed from this } \\
\text { sentence. }\end{array}$ & The phrase was removed. \\
\hline 5. & $\begin{array}{l}\text { Page } 33, \\
\text { Section } 3.2,2 \text { nd } \\
\text { Full Paragraph, } \\
\text { Last Two } \\
\text { Sentences }\end{array}$ & $\mathrm{E}$ & $\begin{array}{l}\text { The DOE/NV (1997a) reference cited in these two } \\
\text { sentences needs to be added to Section } 5.0 \text { of the } \\
C A D D / C A P \text {. }\end{array}$ & The references were added. \\
\hline 6. & $\begin{array}{l}\text { Page } 42 \text {, } \\
\text { Section } 4.2 \text {, } \\
\text { Rock Valley } \\
\text { Fault, } \\
\text { Top of Page, } \\
\text { Last Sentence }\end{array}$ & $\mathrm{E}$ & $\begin{array}{l}\text { The DOE/NV (1997b) reference cited in this sentence } \\
\text { needs to be added to Section } 5.0 \text { of the CADD/CAP. }\end{array}$ & The references were added. \\
\hline 7. & $\begin{array}{l}\text { Page } 43, \\
\text { Figure 4-3: }\end{array}$ & $\mathrm{T}$ & $\begin{array}{l}\text { In the figure, the furthest extent of Cambric contaminant } \\
\text { boundary touches the outer envelope of the Rock Valley } \\
\text { Fault System in contrast to the Figure } 4-2 \text { delineation. The } \\
\text { two figures should be consistent. }\end{array}$ & The figure was revised to be consistent. \\
\hline 8. & $\begin{array}{l}\text { Page } 44, \\
\text { Section } 4.4 .1 \\
1 \text { st paragraph, } \\
7 \text { th sentence }\end{array}$ & $\mathrm{T}$ & $\begin{array}{l}\text { "and all the information pertaining to either decision has } \\
\text { been fully documented in the Model Evaluation Report" } \\
\text { should be added to the end of this sentence. }\end{array}$ & $\begin{array}{l}\text { "and all the information pertaining to either decision } \\
\text { has been fully documented in the Model Evaluation } \\
\text { Report" was added. }\end{array}$ \\
\hline 9. & $\begin{array}{l}\text { Page 53, } \\
\text { Figure 4-6 }\end{array}$ & $\mathrm{E}$ & $\begin{array}{l}\text { For clarity the title of this figure should be "Well ER-11-2 } \\
\text { Construction Details." }\end{array}$ & The title was changed as suggested. \\
\hline 10. & $\begin{array}{l}\text { 10. Page } 54, \\
\text { Figure } 4-7\end{array}$ & $\mathrm{E}$ & $\begin{array}{l}\text { For clarity the title of this figure should be "Well ER-5-5 } \\
\text { Construction Details." }\end{array}$ & The title was changed as suggested. \\
\hline 11. & $\begin{array}{l}\text { 11. Page } 55 \text {, } \\
\text { Section } 4.5 .2 \\
5 \text { th bullet }\end{array}$ & $\mathrm{T}$ & $\begin{array}{l}\text { With the limited wells located in the Northern Testing Area } \\
\text { as presented in Figure } 1-2 \text {, how will the data from the two } \\
\text { new wells lead to evaluating the velocity constraints? Will } \\
\text { the velocity be determined only with these two wells or } \\
\text { will all possible well pairs be considered? }\end{array}$ & $\begin{array}{l}\text { All possible well pairs will be considered. This was } \\
\text { added to the document. }\end{array}$ \\
\hline 12. & $\begin{array}{l}\text { Page } 57 \\
\text { Section } 4.5 .3\end{array}$ & $\mathrm{~T}$ & $\begin{array}{l}\text { List of locations planned for quarterly water-level } \\
\text { measurements: Why is UE-5c WW (shown on Figure 1-2) }\end{array}$ & $\begin{array}{l}\text { The figure was revised to be consistent with the list. } \\
\text { There is no access line in this supply well. USGS }\end{array}$ \\
\hline
\end{tabular}

${ }^{a}$ Comment Types: $\mathrm{T}=$ Technical, $\mathrm{E}=$ Editorial. 
NEVADA ENVIRONMENTAL RESTORATION PROJECT

UGTA DOCUMENT REVIEW SHEET

\begin{tabular}{|l||l||l||l||l||}
\hline $\begin{array}{l}\text { 10. Comment } \\
\text { No. (Priority) }\end{array}$ & $\begin{array}{l}\text { 11. Location } \\
\text { (Pg, Sect, Line) }\end{array}$ & 12. Type & 13. Comment & 14. Comment Response \\
\hline \hline & & & not included in this list? & $\begin{array}{l}\text { monitors the water withdrawals from this well, } \\
\text { although other than for sampling, it hasn't been pumped } \\
\text { in the last few years because of arsenic issues. } \\
\text { Recompleting UE-5c WW for the purpose of water- } \\
\text { level monitoring is not considered to add value. Access } \\
\text { is restricted and the data primarily affects the } \\
\text { CAMBRIC ditch plume, for which we have closer, } \\
\text { more appropriate observation wells (ER-5-4, RNM-2S, } \\
\text { and-5n). }\end{array}$ \\
& & & &
\end{tabular}


From:

Sent:

To:

Subject:
Farnham, Irene (CONTR)

Thursday, June 30, 2011 5:00 PM

'Christine Andres'

FW: Frenchman Flat CADD/CAP Comment Responses

Chris,

Here are the final comments by Joe Fenelon and the changes made to the CADD/CAP as a result of the comments. Please let me know if you have any questions or would like me to modify my responses.

Also, Susan loaded the Frenchman Flat Self Assessment to the SharePoint exchange site. Bill may not get a chance to approve the transfer until next week. He is still in a meeting.

Thank you!

Irene

1) Pg. 25, $2^{\text {nd }}$ full paragraph, $2^{\text {nd }}$ sentence - Pre-emptive review comment: All are within OAA according to Table 2-3.

\section{Response:}

Text was revised to read (highlighted words are the only changes): PIN STRIPE and MILK SHAKE usually have the largest contaminant boundaries and are present in the welded and vitric tuffs at the northern basin edge and BLFA, respectively. The contaminant boundaries of the other tests in the Northern Testing Area are primarily within the OAA. The PIN STRIPE test was conducted in the TM-LVTA, and the contaminants are principally forecasted to migrate eastward in the TSA, the saturated volcanic unit beneath the TM-LVTA. The MILK SHAKE test was performed in the OAA with the contaminants principally forecasted as migrating southeast in the BLFA with some penetration into the alluvium. Contaminants from the PIN STRIPE test are forecast to migrate vertically no more than $15 \mathrm{~m}$ below the water table within 1,000 years as they travel through the TSA; whereas those for the MILK SHAKE test extend to $60 \mathrm{~m}$ below the water table at the cavity and $48 \mathrm{~m}$ at the southern end (NNES, 2010b).

2) Pg. 26, $2^{\text {nd }}$ full paragraph, $1^{\text {st }}$ sentence - Pre-emptive review comment: Not clear which tests these are from table 2-3. All are within OAA.

\section{Response:}

Text was revised to read: The five beta emitters included in the MILK SHAKE and PIN STRIPE simulations completely reproduced the total forecasted amount of contaminated groundwater for the other five tests conducted in the northern testing area supporting the exclusion of the other species. For all tests in the northern testing area except MILK SHAKE, the major species contributing to the contaminant boundary, in decreasing order of impact, were ${ }^{3} \mathrm{H},{ }^{14} \mathrm{C},{ }^{36} \mathrm{Cl},{ }^{129} \mathrm{I}$, and ${ }^{99} \mathrm{Tc}$. MILK SHAKE has the same ranking with the reverse order of ${ }^{14} \mathrm{C}$ and ${ }^{3} \mathrm{H}$. The quick release, high activity, and rapid decay of ${ }^{3} \mathrm{H}$ is apparent before 200 years, after which the longer-lived radionuclides dominate.

3) Pg. 26, $1^{\text {st }}$ full paragraph, $3^{\text {rd }}$ sentence and Pg. 49, Continuity of BLFA row - The question still remains as to how can 3 isolated flows be differentiated from erosional remnants of a single large flow. One would presume that the erosional remnants are isolated bodies also. What the comment suggested is that the aeromag should try to resolve whether the lavas are isolated pieces or all connected as part of one extensive flow. 


\section{Response:}

The last part of the sentence (i.e., and determine whether the BLFA comprises three separate flows or erosional remnants of a single large flow) was deleted from both pages because the aeromag data is not expected to allow us to determine whether the BLFA comprises three separate isolated flows or if it is an erosional remnant of a single large flow.

4) Pg. 59 ( 1 st full sentence) - This seems to imply that only the 1 st of the 2 initial wells will be installed, completed, and tested.

\section{Response:}

Text was revised to read: Installation, completion, and testing of the first two model evaluation wells (ER-5-5 and ER-11-2) will be conducted next.

Irene Farnham, Ph.D.

Underground Test Area Project

Supporting Navarro-Intera contracted to the

U.S. Department of Energy, NNSA Nevada Site Office

232 Energy Way

North Las Vegas, NV 89030

Office: (702) 295-6469

Fax: (702) 295-2025 
From:

Sent:

To:

Cc:

Subject:
Christine Andres [CANDRES@ndep.nv.gov]

Tuesday, July 05, 2011 2:36 PM

Farnham, Irene (CONTR)

Wilborn, Bill R (NEV); Ruskauff, Greg (CONTR); Britt Jacobson; Mark McLane

RE: Frenchman Flat CADD/CAP

Irene,

Britt, Mark and I discussed your email and its suggestions. If a sentence or two is added to the CADD/CAP that a drilling advisory team (section A.3.5.4 of the QAPP) will be responsible for making the decision(s) on which geophysical logs, etc. need to be run in the model evaluation wells then we have no problem with the removal of Table 4-3 and the associated paragraph on pages 51 and 55.

Because this is a change to Rev. 0 of the CADD/CAP and a change to our normal review procedures, we are requesting that an Appendix of Rev.1 contain:

1) our Rev.0 Document Review Sheet

2) your June 30, 2011 responses to Joe Fenlon's comments

3) a copy of today's email request and our reply

If you have any questions or comments, just give me a call.

Thanks,

Chris

Christine D. Andres, C.P.M.

Environmental Scientist IV

Supervisor

Bureau of Federal Facilities

Nevada Division of Environmental Protection

2030 E. Flamingo Road

Suite 230

Las Vegas, NV 89119

p: $702-486-2850$ ext. 232

f: $702-486-2863$

email: candres@ndep.nv.gov

From: Farnham, Irene (CONTR) [mailto:I rene.Farnham@nv.doe.gov]

Sent: Tuesday, July 05, 2011 1:08 PM

To: Christine Andres

Cc: Ruskauff, Greg (CONTR); Wilborn, Bill R (NEV)

Subject: RE: Frenchman Flat CADD/CAP

Chris,

Please forgive me for this! In a recent conversation between Bill Wilborn, Greg Ruskauff, and I it was proposed that Table 4-3 be removed from the Frenchman Flat CADD/CAP. The plan to perform geologic and geophysical logging is stated in Table 4-2. We believe that Table 4-3 contains much more detail than is necessary for a CADD/CAP. We also do not think that all of these logs are necessary to address the model evaluation targets presented in Table 4-2 (i.e., evaluating the continuity of BLFA and TSA HSUs).

We also propose the removal of the last paragraph on page 51 (including the first three lines on page 55). This keeps the description of the data-collection activities presented in Table 4-2 all at the same level of detail.

Please let me know if this is acceptable to you. 
Thank you so much for your patience!

Irene

Irene Farnham, Ph.D.

Underground Test Area Project

Supporting Navarro-Intera contracted to the

U.S. Department of Energy, NNSA Nevada Site Office

232 Energy Way

North Las Vegas, NV 89030

Office: (702) 295-6469

Fax: (702) 295-2025 


\title{
Library Distribution List
}

\author{
$\underline{\text { Copies }}$ \\ U.S. Department of Energy \\ 1 (Uncontrolled, electronic copy) \\ National Nuclear Security Administration \\ Nevada Site Office \\ Technical Library \\ P.O. Box 98518, M/S 505 \\ Las Vegas, NV 89193-8518 \\ U.S. Department of Energy \\ 1 (Uncontrolled, electronic copy) \\ Office of Scientific and Technical Information \\ 1 (Uncontrolled, electronic copy) \\ P.O. Box 62 \\ Oak Ridge, TN 37831-0062 \\ Southern Nevada Public Reading Facility \\ 2 (Uncontrolled, electronic copies) \\ c/o Nuclear Testing Archive \\ P.O. Box 98521, M/S 400 \\ Las Vegas, NV 89193-8521 \\ Manager, Northern Nevada FFACO \\ 1 (Uncontrolled, electronic copy) \\ Public Reading Facility \\ c/o Nevada State Library \& Archives \\ 100 N Stewart Street \\ Carson City, NV 89701-4285
}

